\title{
Pre- and intraoperative gut irrigation and antibiotics in colorectal surgery : a clínical and experimental study
}

Citation for published version (APA):

Mahabier, C. (1989). Pre- and intraoperative gut irrigation and antibiotics in colorectal surgery : a clinical and experimental study. [Doctoral Thesis, Maastricht University]. Rijksuniversiteit Limburg. https://doi.org/10.26481/dis.19891124cm

Document status and date:

Published: 01/01/1989

DOI:

$10.26481 /$ dis. $19891124 \mathrm{~cm}$

Document Version:

Publisher's PDF, also known as Version of record

\section{Please check the document version of this publication:}

- A submitted manuscript is the version of the article upon submission and before peer-review. There can be important differences between the submitted version and the official published version of record.

People interested in the research are advised to contact the author for the final version of the publication, or visit the DOI to the publisher's website.

- The final author version and the galley proof are versions of the publication after peer review.

- The final published version features the final layout of the paper including the volume, issue and page numbers.

Link to publication

\footnotetext{
General rights rights.

- You may freely distribute the URL identifying the publication in the public portal. please follow below link for the End User Agreement:

www.umlib.nl/taverne-license

Take down policy

If you believe that this document breaches copyright please contact us at:

repository@maastrichtuniversity.nl

providing details and we will investigate your claim.
}

Copyright and moral rights for the publications made accessible in the public portal are retained by the authors and/or other copyright owners and it is a condition of accessing publications that users recognise and abide by the legal requirements associated with these

- Users may download and print one copy of any publication from the public portal for the purpose of private study or research.

- You may not further distribute the material or use it for any profit-making activity or commercial gain

If the publication is distributed under the terms of Article $25 \mathrm{fa}$ of the Dutch Copyright Act, indicated by the "Taverne" license above, 


\title{
Pre- and intraoperative gut irrigation and antibiotics in colorectal surgery
}

\author{
a clinical and experimental study
}

\author{
Proefschrift
}

ter verkrijging van de graad van doctor in de Geneeskunde aan de Rijksuniversiteit Limburg te Maastricht op gezag van de Rector Magnificus, prof. dr F. I. M. Bonke, volgens het besluit van het College van Dekanen in het openbaar te verdedigen in de aula van de universiteit. op vrijdag 24 november 1989

om 16.00 uur door

\section{Chander Mahabier}

geboren in het district Nickerie in Suriname. 
Promotores: $\quad$ Prof. dr C.P.A. van Boven

Prof. dr J.M. Greep

Co-promotores: $\quad$ Dr J.D.K. Munting

Dr B.I. Davies

Beoordelingscommissie: Prof. dr R.A. Janknegt (voorzitter)

Prof. dr P.J. Brombacher

Prof. H.A.F. Dudley (St. Mary's Hospital, London)

Prof. dr J.A. Gruwez (Katholieke Universiteit Leuven)

Prof. dr P.B. Soeters 
'Bloom where you are planted'

To Mieke,

Shanti, Ratha and Kiran.

To the memory of my father and mother. 


\section{Contents}

Chapter 1

Aim of the study

Part I

Review of the literature

Chapter 2

Bowel preparation for elective colorectal surgery 15

Bowel preparation: sense or nonsense ?

Methods of bowel preparation 16

$\begin{array}{ll}\text { Conventional } & 17\end{array}$

$\begin{array}{ll}\text { Elemental diets } & 17\end{array}$

$\begin{array}{ll}\text { Whole gut irrigation } & 17\end{array}$

Mannitol $\quad 17$

Conclusions 18

$\begin{array}{ll}\text { References } & 19\end{array}$

\section{Chapter 3}

Intraoperative colon irrigation 25

$\begin{array}{ll}\text { History } & 25\end{array}$

$\begin{array}{lr}\text { Indications } & 29\end{array}$

$\begin{array}{ll}\text { Obstructions } & 29\end{array}$

Diverticulitis $\quad 29$

Non obstructing tumours $\quad 29$

$\begin{array}{ll}\text { Perforations } & 29\end{array}$

Major colonic haemorrhage $\quad 30$

Fistulae 31

Closure of a diverting colostomy 31

Volvulus $\quad 31$

Contraindications $\quad 32$

Results in the literature $\quad 32$

References $\quad 33$ 


\section{Part II}

Clinical studies

\section{Chapter 4}

Prophylactic antimicrobials and whole gut irrigation in elective colorectal surgery: a prospective randomised study

Introduction $\quad 42$

Patients and methods $\quad 42$

Prophylactic regimens $\quad 43$

Exclusion after admission to trial 44

Observations 44

Colonic bacterial counts at operation $\quad 45$

Bacteriological methods $\quad 45$

Definitions $\quad 45$

Operative procedures $\quad 45$

Statistics $\quad 46$

Results $\quad 46$

Patient population $\quad 46$

Bacteriological results $\quad 47$

Wound infections $\quad 48$

Anastomotic leakage $\quad 50$

Sepricaemia $\quad 50$

Seriousness of wound infection and anastomotic leakage $\quad 50$

Mortality $\quad 52$

Postoperative hospitall stay $\quad 52$

Anterior resections $\quad 52$

Prospective study group $1984-87$

Discussion 55

Conclusions $\quad 58$

References $\quad 59$ 


\section{Chapter 5}

Intraoperative colon irrigation to permit left sided primary resection and anastomosis in the unprepared colon.

Introduction 65

Methods $\quad 65$

Definitions 65

Surgical strategy 66

Preoperative management $\quad 66$

Operative technique 66

Postoperative management 69

Early modifications to the technique 69

Patients 69

Results $\quad 73$

Discussion $\quad 75$

Management of the lesions of the right colon 75

Management of the lesions of the left colon $\quad 76$

Indications and contraindications $\quad 77$

$\begin{array}{ll}\text { Duration of the procedure } & 77\end{array}$

Colostomy

Staged resection; mortality and morbidity $\quad 78$

$\begin{array}{ll}\text { Wound infection } & 79\end{array}$

$\begin{array}{ll}\text { Prognosis } & 79\end{array}$

$\begin{array}{ll}\text { Conclusions } & 79\end{array}$

References $\quad 80$

\section{Chapter 6}

Development of new instruments and subsequent modifications to the intraoperative colon irrigation technique

Introduction $\quad 85$

New instruments $\quad 85$

Irrigation needle $\quad 85$

Irrigation drainage tube $\quad 89$

Rectal tube $\quad 92$

Late modifications $\quad 93$

Acute colon decontamination $\quad 93$

Transcaecal ileal diversion $\quad 93$

References

94 


\section{Part III}

Experimental study

Chapter 7

Experiments on the efficacy of antibiotics used in induced intraabdominal sepsis and their predictive value in colorectal surgery 96 Introduction $\quad 96$

$\begin{array}{ll}\text { Materials and methods } & 97\end{array}$

Animals: $\quad 97$

Operative procedure $\quad 97$

$\begin{array}{ll}\text { Antibiotics } & 99\end{array}$

Collection and processing of specimens 99

Evaluation of the results 99

$\begin{array}{ll}\text { Results } & 100\end{array}$

$\begin{array}{ll}\text { Control group } & 100\end{array}$

$\begin{array}{ll}\text { Neonycin-metronidazole } & 100\end{array}$

$\begin{array}{ll}\text { Tobramycin-metronidazole } & 100\end{array}$

Tetracycline 100

Amoxycillin-clavulanate $\quad 100$

$\begin{array}{ll}\text { Imipenem } & 100\end{array}$

Ticarcillin-clavulanate $\quad 101$

$\begin{array}{ll}\text { Discussion } & 102\end{array}$

$\begin{array}{ll}\text { Conclusions } & 103\end{array}$

$\begin{array}{ll}\text { References } & 104\end{array}$

\section{Chapter 8}

The influence of antibiotics on colonic anastomosis in rats: evaluation by bursting pressure measurement 105 $\begin{array}{ll}\text { Introduction } & 105\end{array}$

Materials and methods 106

$\begin{array}{ll}\text { Animals } & 106\end{array}$

$\begin{array}{ll}\text { Housing } & 106\end{array}$

$\begin{array}{ll}\text { Diet } & 106\end{array}$

$\begin{array}{ll}\text { Antibiotics } & 106\end{array}$

$\begin{array}{ll}\text { Infected anastomoses } & 106\end{array}$

$\begin{array}{ll}\text { Bowel preparation } & 106\end{array}$

$\begin{array}{ll}\text { Whole gut irrigation } & 107\end{array}$

$\begin{array}{ll}\text { Intraoperative colon irrigation } & 107\end{array}$

$\begin{array}{ll}\text { Study groups } & 107\end{array}$

$\begin{array}{ll}\text { Bursting pressure } & 109\end{array}$

$\begin{array}{ll}\text { The operation } & 109\end{array}$

Autopsy procedure $\quad 110$

Results

Discussion

$\begin{array}{ll}\text { Conclusions } & 117\end{array}$

$\begin{array}{ll}\text { References } & 118\end{array}$ 


\section{Chapter 9}

Acute intraoperative decontamination of the colon:

an experimental study

Introduction

Materials and methods

In vitro study

Technique of the intraoperative colon irrigation

Results

Discussion

References

\section{Chapter 10}

Protocol for the treatment of colonic disease in elective and emergency surgery

Summary and conclusions

Samenvatting en conclusies 


\section{Chapter 1}

\section{Aim of the study}

\section{Introduction}

The use of antibiotic prophylaxis in elective colorectal surgery is now generally accepted [I] although the method of drug administration (oral or parenteral) and the duration are variable. A 24 hour prophylaxis (three doses) is most commonly used but some workers estimate that one single intravenous dose at the induction of ancesthesia would be sufficient [2].

Several antibiotics have been reported to be effective as prophylaxis in colorectal surgery. Although some surgeons claim that antibiotics active only against anaerobic bacteria provide adequate protection [3], it is commonly considered that drugs effective against the derobic as. well as the anaerobic colonic fllora should be employed as prophylactic agents [4].

The adverse effect of faecal loading on the healing of colonic anastomoses has been reported in many clinical and experimental studies [5]. Bowel preparation, in order to get rid of the faecal mass in the colon, is generally claimed to be essential for the prevention of anastomotic leakage and postoperative septic complications (in combination with antibiotics) [6]. The studies on colorectal surgery reported in this thesis consist of a clinical and an experimental part.

\section{Clinical study}

\section{Preoperative whole gut irrigation and antibiotics}

Before 1979, oxytetracycline was used in the De Wever-Ziekenhuis. Heerlen, as. prophylaxis in elective colorectal surgery, combined with a conventional bowel preparation using diets and laxatives for several days.

In 1979 a prospective randomized study was set up to evaluate the results of different antibiotics (including oxytetracycline) in combination with whole gut irrigation (WGI) as bowel pieparation.

The aim was to compare the former policy of antibiotic prophylaxis with other combinations and to make the best choice for day to day use in the hospital.

Results of a prospective and randomized study in 212 patients are reported, as well as. additionally, those obtained in 215 patients who were treated with the regimen yielding the best results in the randomized study.

\section{Intraoperative colon irrigation}

Preoperative whole gut irrigation or other means of bowel preparation appeared to be difficult or impossible in patients with obstructing tumours.

A staged surgical procedure (including diverting colostomy, resection of the lumour at a second operation and closure of the colostomy at a third, or the use of the Hartmann 
procedure) was the orthodox treatment for these patients. Intraoperative colon irrigation, permitting bowel preparation to a high standard during operation, enables the performance of a one-slage operation (primary resection and anastomosis) in patients with obstruction of the left colon, and was introduced in 1984. The experience and results with this procedure in 41 patients are reported.

\section{Experimental studies}

\section{Evaluation of antibiotics}

Animal experiments were carried out to investigate three clinically posed questions:

1. Is an evaluation of an antibiotic regimen for prophylaxis in an experimental animal model feasible, prior to its use in longlasting clinical trials?

The antibiotic regimens used in the clinical trial were also evaluated in an experimental intra-abdominal infection model $[7]$ and the clinical and experimental results were compared. Several new antibiotics have been evaluated as prophylactic agents in colorectal surgery using this model.

\section{Antibiotics and anastomotic healing}

2. Is it safe to perform an anastomosis in the presence of infection provided antibiotics are given? Or, in other words: could antibiotics diminish the effect of perianastomotic infection and promote unimpaired anastomotic healing?

An experimental study was carried out using previously infected Vicryl ${ }^{R}$ for the performance of the anastomosis. Bursting pressure measurements in the isolated colon containing the anastomosis at the 3rd and 7 th day were used as parameters of anastomotic healing.

\section{Acute colon decontamination}

3. Can the colon be rapidly decontaminated by intraoperative lavage with povidone iodine?

Adequate serum levels of antibiotics and the reduction of the bacterial burden by whole gut irrigation with neomycin and metronidazole have been shown to be very effective in the prevention of septic complications in elective colorectal surgery [8].

During surgery of obstructing lesions of the colon an adequate level of antibiotics can easily be obtained by intravenous administration shortly before operation. No reduction of the colon llora, either with these antibiotics or by intraoperative colon irrigation, however, is to be expected.

In order to reduce the colon flowa a method of acute colon decontamination was studied experimentally, and subsequently used in patients undergoing intraoperative colon irrigation. 


\section{References}

1. Baum ML, Anish DS, Chalmers TC, Sacks HS, Smith H Jr, Fagerstrom RM.

A survey of clinical trials of antibiotic prophylaxis in colon surgery: evidence against further use of no-treatment controls.

N Engl J Med 1981;305:795-9.

\section{Higgins AF, Lewis A, Noone P, Hole ML.}

Single and multiple dose cotrimoxazole and metronidazole in colorectal surgery.

Br J Surg 1980;67:90-2.

\section{Eykyn S, Jackson BT, Lockhart-Mummery HE, Phillips I.}

Prophylactic peroperative intravenous metroniclazole in elective colorectal surgery.

Lancet 1979;2:761-4.

\section{Roland M, Bergan T, Bjerkeset T, et al.}

Prophylactic regimens in colorectal surgery: comparisons between metronidazole used alone or with ampicillin for one or three days.

World J Surg 1985;9:626-32.

\section{Irvin TT, Goligher JC.}

Aetiology of disruption of intestinal anastomosis.

Br J Surg 1973;60:461-4.

\section{Nichols RL, Condon RE.}

Preoperative preparation of the colon.

Surg Gynecol Obstet 1971;132:323-37.

\section{Lahnborg G, Hedstrom KG, Nord CE.}

Efficacy of different antibiotics in the treatment of experimentally induced intra-abdominal sepsis.

J Antimicrob Chemother 1982;10:497-504.

\section{Weidema WF, Bogaard AE van den.}

Whole gut irrigation and antimicrobial prophylaxis in elective colorectal surgery.

Neth J Surgery 1984;supp: 5:1-108. 


\section{Part I}

\section{Review of the literature}




\section{Chapter 2}

\section{Bowel preparation for elective colorectal surgery}

\section{Bowel preparation: sense or nonsense?}

The large bowel is heavily colonised by aerobic and anaerobic bacteria, the latter being 10,000 times more numerous. The most common aerobic organisms are Escherichia coli and Enterococcus faccalis, and the most common anaerobic bacteria belong to the species of Bacteroides and Clostridium [1]. During surgery, once the colonic wall is opened and faecal spillage occurs, sepsis almost invariably occurs unless appropriate antibiotic prophylaxis is given.

Wound infection after gastrointestinal operations is nearly always caused by endogenous bacterial flora contaminating the wound at operation [2]. The development of wound sepsis depends not only upon the species of bacteria inoculated into the wound but also upon their number. Experimental models suggest that direct inoculation of $10^{6}$ organisms $/ \mathrm{ml}$ is required to produce sepsis reliably, whereas if the number of organisms is $<10^{5} / \mathrm{ml}$ wound sepsis develops less often [3]. Thus, the greater the bacterial contamination the greater the risk and the higher the probability of sepsis [4].

Another finding of importance has been suggested by Rusca et al. [5]. In an experimental study it has been shown that bacteria which cause disruption of an anastomosis are probably seeded at the time of the creation of the anastomosis and do not leak out after the anastomosis has been performed.

Secondly, the presence of formed faeces in the intestinal tract proximal to a recently fashioned anastomosis poses a threat to that anastomosis. Therefore to leave an anastomosis, however carefully made, distal to a length of bowel loaded with formed faeces is to court disaster [6]. The dangers occur when bowel function returns after operation, for a bolus of hard faeces may become impacted at the anastomosis site. This will result in tension and ischaemia at the suture line, with the risk of anastomotic breakdown, leakage and gross faecal contamination of the abdomen.

Experimental and clinical investigations $17,8 \|$ emphasise the disastrous effect of faecal loading on colonic anastomoses, so causing postoperative septic complications.

Hence the purpose of preoperative large bowel preparation is to reduce the risk of laecal spillage and bacterial contamination of the abdomen during colorectal surgery. The risk cannot entirely be avoided, but the frequency and severity of bacterial spillage can be minimised by good operative technique and optimal bowel preparation.

There is a popular misconception that reduction in faecal residue (by bowel preparation) is associated with reduced counts of bacteria in the colon. Mechanical bowel preparation, however, will never decrease the number of residual microorganisms per $\mathrm{ml}$ of stool (concentration) in the colon at the time of operation and no decrease of postoperative complications is to be expected from this preparation alone $[9,10,11]$. 
Reducing colonic aerobic and anaerobic bacterial flora is achieved by using oral antibiotics [12] and is used by some workers to minimise the endogenous bacterial infection so that prophylactic antibiotics can more effectively combat the organisms invading the wound [13].

Irving and Scrimgeour in their recent publication [14] questioned the basic truisms of large bowel preparation in elective and emergency colorectal surgery. They described excellent results in 46 patients undergoing leftsided colonic resections and primary anastomosis without any bowel preparation. They argue that preoperative bowel preparation is time consuming, expensive, unpleasant to the patient and completely unnecessary! Provided a single dose of appropriate antibiotics is administered intravenously at the start of the operation, these workers claim that all forms of bowel preparation can be omitted.

The problem is that comparison of their results is scarcely possible because hardly any one else has used their methods. Secondly, the number of patients in their study is too small to be conclusive.

At one point their assumption has already been proven to be incorrect. Phillips et al. [15] (in the Large Bowel Cancer project), reported on a large number of patients (including 713 with obstructions) and noted a statistically significant difference in anastomotic leakage between patients without obstruction (6\% leakage) and those who were indeed obstructed $(18 \%)$. All underwent immediate resection and anastomosis without any bowel preparation.

The answer to the question concerning the sense or nonsense of large bowel preparation in elective colorectal surgery (with reference to the publication of Irving and Scrimgeour) can only be answered by prospective trials with sufficient and comparable groups of patients (degree of illness; staging of the tumour), with comparable operative technique (the use of one-or two-layer anastomoses; use of drains, defunctioning colostomy etc.) in whom the mechanical bowel preparation is studied as a single variable [16]. Such a trial will probably never take place for ethical reasons and the large number of patients required.

In view of the good results of optimal bowel preparation combined with perioperative antibiotic prophylaxis in elective colorectal surgery, it can be concluded that this basic surgical practice should not be violated.

\section{Methods of bowel preparation}

The ideal method of mechanical bowel preparation should completely empty the colon without distress to the pationt. Such a method should be cheap, require a mininum of nursing time and not result in water and electrolyte imbalance. Ideally the colonic concentration of bacteria should be reduced to such an extent that systemic prophylaxis is not required and there should be no development of bacterial resistance or risk of superinfection. Unfortunately, no such ideall method exists. A balance, therefore, has to be struck between the desire of the surgeon to empty the colon of faeces and the degree of distress caused to the patient.

A number of different techniques can be used to clear the colon of faecal material. These include conventional bowel preparation with low or non residue diets, cathartics and enemats. whole gut irrigation (WGI), oral (mannitol or polyethylene glycol) bowel preparation and intraoperative colonic irrigation. 


\section{Conventional bowel preparation}

This technique of bowel preparation has been used for many years [6]. II requires the admission of the patients to hospital 3-5 days before operation. A low residue diet is commenced, and this becomes a "fluid only" diet 1-2 days before surgery. Purgation with one of a variety of laxatives (senna, magnesium sulphate, castor oil etc.) is given for 2 days, followed by enemata and rectal lavage for 1 day $[17]$.

This method provides excellent clearance of the colon, but it is exhausting for the patient, who comes to operation in a state of starvation; it also results in electrolyte loss [181. It is time-consuming for the nurses and the patient and is expensive.

\section{Elemental diets}

Elemental Diets (Peptison ${ }^{\mathrm{R}}$; Nutrison ${ }^{\mathrm{R}}$ ) are designed to be absorbed totally within the small bowell so that no residue passes through the colon, while providing an adequate nitrogen and calorie intake for the patient.

It was thought that taking such a diet for several days preoperatively might provide the advantage of a low residue diet without the disadvantage of the starvation encountered with conventional bowel preparation. However, it has been found that such a diet neither empties the colon of faeces nor reduces the concentration of microorganisms within the colon [19]. The use of such diets has not gained great favour, but their value is that they maintain adequate preoperative nutrition in the debilitated patient [20].

Conventional bowel preparation and elemental diets both require considerable time in order to prepare the colon, and because of admission of patients to the hospital several days before operation to complete bowel preparation these methods are therefore also expensive. Within the last few years 3 methods of orthograde colonic lavage lawe been introduced in elective colorectal surgery: whole gut irrigation, oral mannitol bowel preparation and oral polyethylene glycol bowel preparation.

\section{Whole gut irrigation (WGI)}

Irrigation of the bowel with an electrolyte solution was first proposed for the trealtnent of cholera [21]. The technique was subsequently modified for use in preoperative bowel preparation [22,23]. The method of irrigation is described in chapter 4.

It provides excellent clearance of the colon (compared with conventional, elemental and mannitol bowel preparation) |24], with little fluid being left [25|, and there is insignificant retention of water at the time of surgery.

There is negligible electrolyte imbalance [26] if an electrolyte solution is used for irrigation. Patient tolerance is good $|27,28,29|$.

\section{Oral mannitol bowel preparation}

Mannitol bowel preparation depends upon the fact that mannitol, an oligosaccharide, is not absorbed. If given ats a hypertonic solution (10-20\%), it draws fluid into the lumen of the bowel by its osmotic action.

If an isotonic solution (5\%) is given by mouth, the fluid is retained within the bowel [30]. 
The purgation is produced by irrigation of the colon with this fluid. The mannitol solution can be flawoured to the patient's taste and is then quite palatable to drink. On the day before operation, $200 \mathrm{~g}$ of mannitol difuted in 11 litre of water $(20 \%), 2$ litres (10\%) of water or 4 litres of water $(5 \%)$ is drunk over a 4-hour period. The main advantage of mannitol as compared to whole gut irrigation is that the use of a nasogastric tube and special toilet facilities are not required.

However many enteric microorganisms (Escherichia coli) ferment mannitol [31] and this results in increased postoperative septic complications, together with an increased risk of colonic explosion $[32-36]$ due to hydrogen from bacterial fermentation. These are the reasons that its use is no longer recommended, despite the fact that addition of appropriate oral antibiotics to the mannitol bowel preparation diminishes the above-mentioned risks.

\section{Bowel preparation with polyethylene glycol electrolyte solution}

Polyethylene glycol (PEG), as an osmotic purgative, is comparable to mannitol but does not have the two above-mentioned side effects, as microorganisms cannot use it as a substrate. Since its introduction in 1980 (37) PEG has been used with balanced electrolyte solution [Golytely] for bowel preparation in patients undergoing colonoscopy or elective colorectal surgery [38-45]. It is usually suggested that an average of 4 litres should be sufficient to produce a clean colon. The advantage of this method therefore should be that there is no need for nasogastric intubation although some patients might still find it difficult to drink 4 litres within 4 hours. Therefore, some workers using PEG [46] introduce a nasogastric tube and irrigate not only with 4 litres but continue untill the rectal effluent is totally clear.

One study compared whole gut irrigation with a balanced electrolyte solution against bowel preparation wilth PEG [47]. The authors prepared 15 patients with only 4 litres of PEG and another 15 with whole gut irrigation until a clear rectal effluent could be obtained. Only 4/15 patients prepared with PEG, as compared with all 15 prepared with WGI, had excellent or good cleansing tesults.

However, when the two different solutions were infused in a double-blind manner (as done in 40 patients) until the rectal effluent was clear, no significant difference in the amount of fluid needed was found. However, significantly less fluid retention occurred with PEG, but this appeared to be the only advantage.

\section{Conclusions}

- Until data from adequate controlled clinical urials prove the contrary, large bowel prepatation before colorectal surgery should be considered essential.

- Whole gut irrigation, with balanced electrolyte solution or with polyethylene glycol until the rectal effluent is clear, is rapid, economical and well tolerated by patients. This method of bowel preparation is the best for its capacity to clean the colon.

- No reduction of bacterial colonic flora or decrease in postoperative septic complications is to be expected from bowel preparation alone. 


\section{References}

\section{Keighley MRB.}

Prevention of wound sepsis in gastrointestinal surgery.

Br J Surg 1977;64:315-8

\section{Jackson DW, Pollack AV, Tindall DS.}

The effect of an antibiotic spray in the prevention of wound infection.

Br J Surg 1971;58:565-8

\section{Elek SD, Conen PE.}

The virulence of Staphylococcus pyogenes for man. A study of the problem of wound infection.

Br J Exp Pathol 1957:38:573-586.

\section{Cruse P.JE, Foord R.}

A five-year prospective study of 23,649 surgical wounds.

Arch Surg 1973;107:206-210.

\section{Rusca JA, Bornside GH, Cohn I Jr.}

Everting versus inverting gastrointestinal anastomoses: bacterial leakage and anastomotic disruption.

Ann Surg 1969;169:727-35.

\section{Muir EG.}

Safety in colonic resection.

J R Soc Med 1968;61:401-8.

\section{Irvin TT, Goligher JC.}

Aetiology of disruption of intestinal anastomosis.

Br J Surg 1973;60:461-4.

\section{Burton RC.}

Postoperative wound infection in colonic and rectal surgery.

Br I Surg 1973;60:363-5.

\section{Bartlett JG, Condon RE, Gorbach SL, Clarke JS, Nichols RL, Ochi S.}

Veterans administration cooperative study on bowel preparation for elective colorectal operations: impact of oral antibiotic regimen on colonic flora, wound irrigation cultures and bacteriology of septic complications.

Ann Surg 1978;188:249-54.

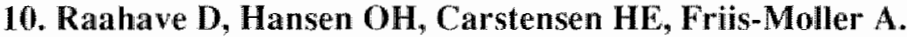

Septic wound complications after whole bowel irrigation before colorectal operations.

Acta Chir Scand 1981;147:215-8.

\section{Weidema WF, Bogaard AE van den.}

Whole gut irrigation and antimicrobial prophylaxis in elective colorectal surgery.

Neth J Surg 1984; suppl 5:1-108. 
12. Arabi $\mathrm{Y}$, Dimock $\mathbf{F}$, Burdon DW, Alexander-Williams J, Keighley MRB. Influence of neomycin and metronidazole on colonic microflora of volunteers. J Antimicrob Chemother 1979;5:531-7.

13. Playforth MJ, Smith GMR, Evans M, Pollock AV. Antimicrobial bowel preparation. Orali parenteral, or both?

Dis Colon Rectum 1988:31:90-3.

\section{Irving $\mathrm{AD}$, Serimgeour $\mathrm{D}$.}

Mechanical bowel preparation for colonic resection and anastomosis.

Br J Surg 1987;74:580-1.

\section{Phillips RK, Hittinger R, Fry IS, Fielding LP.}

Malignant large bowel obstruction.

Bir J Surg 1985;72:296-302.

\section{Johnston D.}

Bowel preparation for colorectal surgery.

Br J Surg 1987:74:553-4.

17. Dodds W.I, Scanlon GT, Shaw DK, Steward ET, Youker JE, Metter GE. An evaluation of colon cleansing regimens.

Am J Roentgenol 1977; 128:57-9.

\section{Mikal S.}

Metabolic effects of preoperative intestinal preparation.

Am J Proctol 1965;16:437-8.

19. Arabi Y, Dimock F, Burdon DW, Alexander-Williams J, Keighley MRB. Influence of bowel preparation and antimicrobials on colonic microllora.

Br J Surg 1978;65:555-8.

\section{Glotzer D.J, Boyle PL, Silen W.}

Preoperative preparation of the colon with an elemental diet.

Surgery 1973;74:703-7.

\section{1, Love AHG, Mitchell TG, Phillips RA.}

Water and sodium absorption in the human intestine.

J Physiol (Jond) 1968; 195:133-40.

\section{Hewitt J, Rigby J, Reeve J, Cox AG.}

Whole-gut irrigation in prepanation for large-bowel surgery.

Lancet 1973:2:337 40.

\section{Crapp AR, Powis SJA, Tullotsen P, Cooke WT, Alexander-Williams J.}

Preparation of the bowel by whole-gut irrigation.

Lancet 1975;2:1239-40.

24. Keighley MRB, Lee JR, Ambrose NS. Indications and techniques for bowel preparation in colorectal cancer.

Int Ady Surg Oncol 1983:6:257-70. 


\section{Hares MM, Alexander-Williams J.}

The effect of bowel preparation on colonic surgery.

World J Surg $\mathbb{1 9 8 2 ; 6 : 1 7 5 \sim 8 1 .}$

26. Kujat R, Grosse H, Gams LE, Pichmayr R.

Veränderungen im Wasser- und Elektrolythaushalt nach orthograder Darmspülung.

Chirurg 1981;52:586-9.

27. Downing R, Dorricott NJ, Keighley MRB, Oates GD, Alexander-Williams J. Whole gut irrigation: a survey of patient opinion.

Br J Surg 1979:66:201-2.

28. Speelman P, Bartelsman JF, Huibregtse $K$, et al.

Reiniging van het colon door totale darmspoeling.

Ned Tijdschr Geneeskd 1981;125:1453-6.

29. Taat CW, Boissevain AC, Coevorden F van, Leguit P Jr, Brummelkamp WH.

Orthograde darmspoeling als preoperatieve darmvoorbereiding bij electieve colorectale chirurgie.

Ned Tijdschr Geneeskd 1981;125:1456-60.

\section{Hindle W, Code CF.}

Some differences between duodenal and ileal absorption.

Am J Physiol 1962;203:215-19.

31. Coevorden F van, Taat CW, Boissevain AC, et al.

Pre-operative whole-gut irrigation with mannitol.

Neth J Surg 1982;34:225-8.

32. Bigard MA, Gaucher P, Lassalle C.

Fatal colonic explosion during colonoscopic polypectomy.

Gastroenterology 1979;77:1307-10.

33. Williams CB, Bartram CI, Bat L, Milito G.

Bowel preparation with mannitol is hazardous.

Gut 1979;20:A933.

34. Taylor EW, Bentley S, Youngs D, Keighlley MRB.

Oral mannitol for bowel preparation is explosive.

Br J Surg 1980;67:821-2.

35. Zanoni CE, Bergamini C, Bertoncini M, Bertoncini L, Garbini A.

Whole-gut lavage for surgery. A case of intraoperative colonic explosion after administration of mannitol.

Dis Colon Rectum 1982;25:580-1.

36. Keighley MRB, Taylor EW, Hares MM, et al.

Influence of oral mannitol bowel preparation on colonic microflora and the risk of explosion during endoscopic diathermy.

Br J Surg 1981;68:554-6. 
37. Davis GR, Santa Ana CA, Morawski SG, Fordtran JS.

Development of a lavage solution associated with minimal water and electrolyte absorption or secretion.

Gastroenterology $1980 ; 78: 991-5$.

38. Coldman J, Retichelderfer M.

Evaluation of rapid colonoscopy preparation using a new gut lavage solution.

Gastrointest Endose 1982;28:9-1.1.

39. Thomas $\mathrm{G}$, Brozinsky $\mathrm{S}$, Isenberg JII.

Patient acceptance and effectiveness of a balanced lavage solution (Golytely) versus the standard preparation for colonoscopy.

Gastroenterology 1982;82:435-7.

40. Ernstoff JJ, Howard DA, Marshall JB, Jumshyd A, McGullough A.J.

A randomized blinded clinical trial of a rapid colonic lavage solution (Golytely) compared with standard preparation for colonoscopy and barium enemat.

Gastroenterology 1983:84:1512-6.

41. DiPalma JA, Brady CE III, Stewart DL, et al.

Comparison of colon cleansing methods in preparation for colonoscopy.

Gastroenterology 1984;86:856-60.

42. Meadows JO, Conyers CT.

Golytely: preparation of choice for colonoscopy.

Gastrointest Endosc 1983;29:256

43. Adler M, Quenon M, Even-Adin D, et al.

Whole gut lavage for colonoscopy-a comparison between two solutions.

Gastrointest Endose 1984;30:65-7.

44. Chan CH, Diner WC, Fontenot E, Davidson BD.

Randomized single-blind clinical trial of a rapid colonic lavage solution (Golytely) vs. standard preparation for barium enema and colonoscopy.

Gastrointest Radiol 1985:10:378-82.

45. Tolia V, Fleming $S$, DuBoís RS.

Use of Golytely in children and adolescents.

J Pediatr Gastroenterol Nutr 1984;3:468-70.

46. Wolff BG, Beart RW Jr, Dozois R et al.

A new bowel preparation for elective colon and rectal surgery. A prospective, randomized clinical trial.

Arch Surg 1988; 123:895-900.

47. Heide $H$ van der, Lantink IA, Wiltink E, Tytgat GNJ.

Comparison of whole-gut irrigation with Golytely (GOL) and with a balanced electrolyte solution (BES) as preparation for colonoscopy.

Endoscopy 1986; 18:182-4. 
48. Dudley HAF, Radcliffe AG, McGeehan D.

Intraoperative irrigation of the colon to permit primary anastomosis.

Br I Surg 1980;67:80-1. 


\section{Chapter 3}

\section{Intraoperative colon irrigation}

\section{History}

Many attempts have been made in the past to clean the colon or rectum during operation before performing a primary resection and anastomosis of the left colon.

In 1958, Windsberg [1] first reported a procedure for irrigating the colon. After mobilisation of the sigmoid and rectum, transsection took place distal to the obstructing tumour. The tumour and the colon were then eased over the left side of the operating table to gravitate toward a large pail outside the sterite field. A circulating nurse was then instructed to make a large opening in the bowel just above the obstructing carcinoma. Bowel contents then gushed out into the pail [fig. 1]. Gentle manipulating and milking of the proximal colon, from the caecum distally, completed the evacuation of nearly all fluid and faeces through the exteriorized limb. Hereafter resection was completed [fig. 2]. If necessary, a large calibre Lewin tube was brought upwards into the bowel above the obstructing cancer and guided towards the right colon. The colon was irrigated through this tube without contamination.
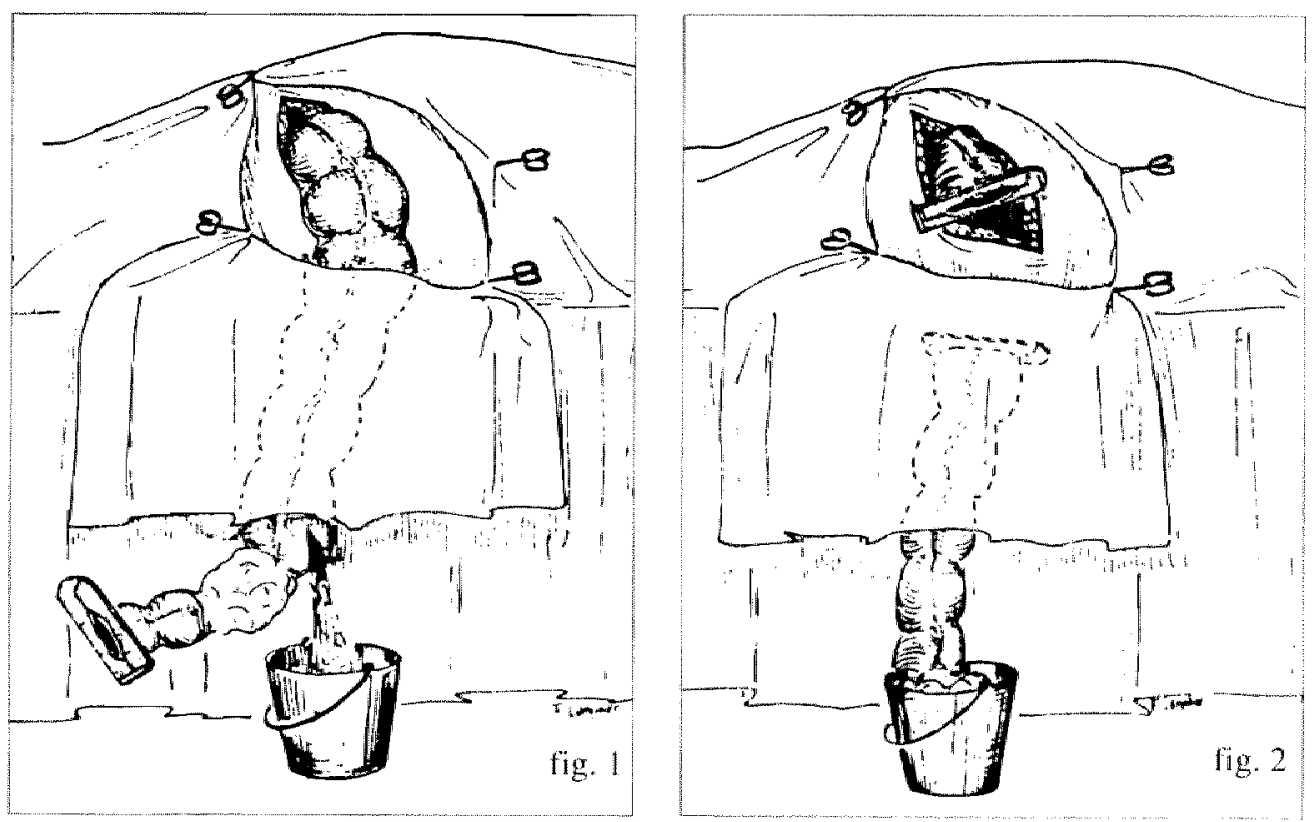

Fig. 1.The exterionized colon is shown hanging over the left side of the table with ant opening made above the obstructing cancer, completing evacuation of bowel and eliminating all distention from Windsberg et al. (1)).

Fig. 2: Wide resection completed (from Windsherg et al. /1]). 

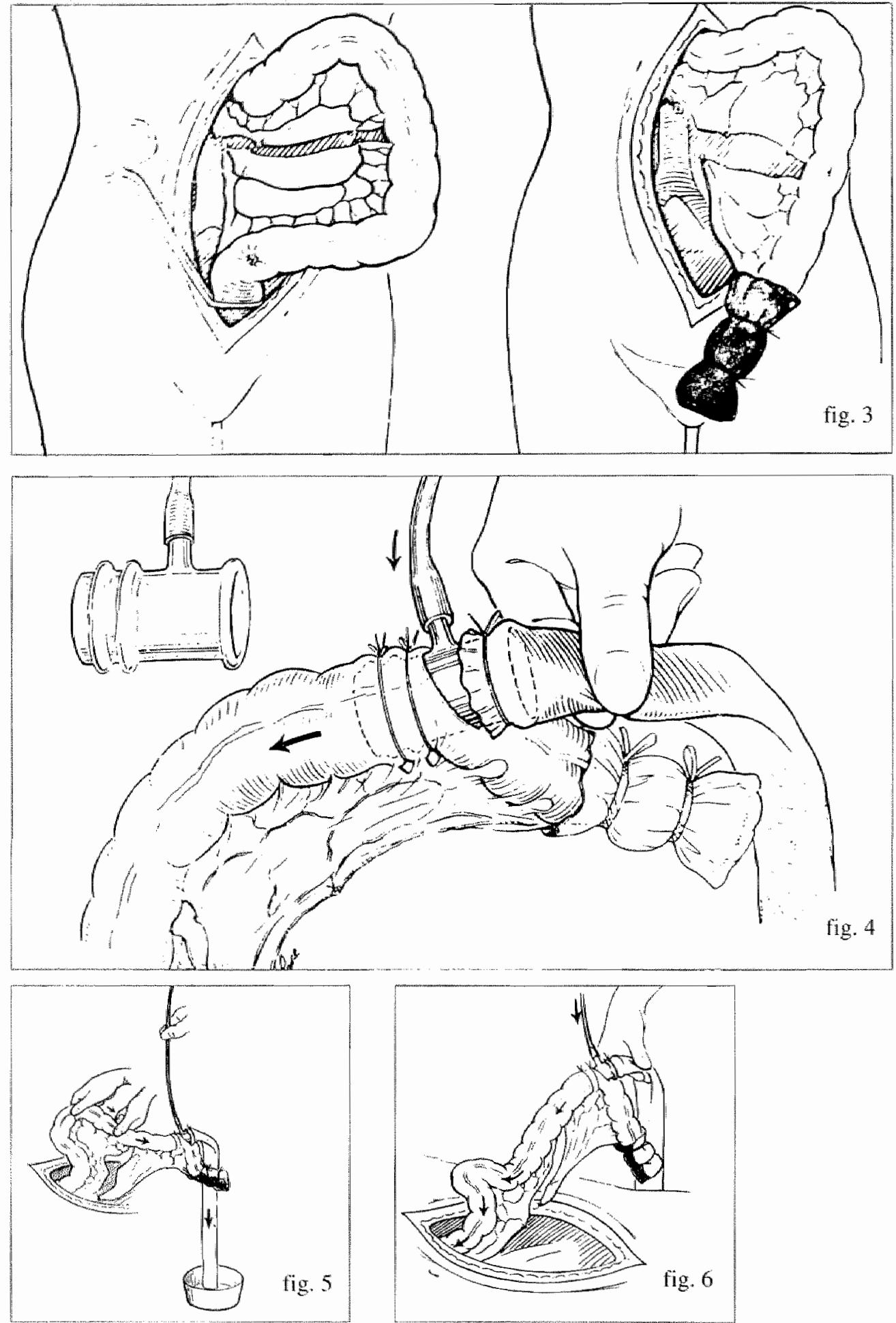
Fig. 3: The fully mobilized segment containing the growth is brought out of the abdomen with its end enclosed in a polyethylene bag (from Muir 21 ).

Fig. 4: A 26 or $32 \mathrm{~mm}$ glass tube with side arm for irrigation is tied securely into the proximal end of the opened bowel from Muir [2]).

Fig. 5. The Paul's tubing is compressed during irrigation, the bowel is lifted up and gentle manipulations used to break up the faecal mass (from Muir [27).

Fig. 6. The bowel is lowered and its contents with the mashings are milked into the Paul's abing which carries them to the waste container beside the table (from Muir [2]).

Fig. 7: The Chaffin Sump drain used for rectal washouts (from Thow $[3]$ ).

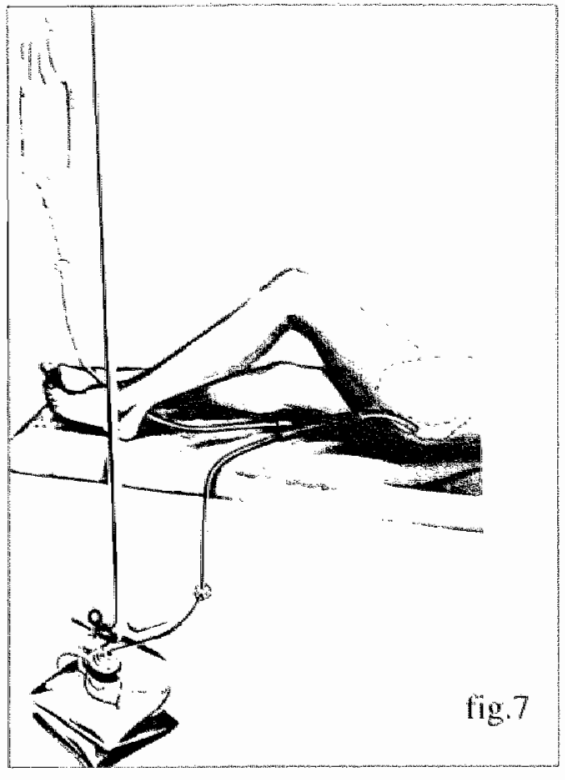

In 1968 Muir [2] introduced a 26 or 32 mm glass tube $\|$ figs. 3 and 4] into the colon proximal to the obstructing tumour, through which irrigation could be performed [igs. 5 and 61.

Thow in 1976 [3] reported the use of the Chaffin Sump for intraoperative rectocolonic irrigation enabling him to pertorm a primary resection and anastomosis [fig. 7 ].

Subsequently in 1979, Rickett[4] used the obturating balloon colostomy (Torbay colostomy) in order to perform a one-stage resection with immediate anastomosis and to leave a colostomy which did not require to be closed. The device consisted of a rigid tube which was bent through 90 degrees. The bent position was incorporated in a soft rubber balloon which was inflated through a Luer connection valve side tube. A flange, secured in place by a screw cap, stabilized the tube in place [figs. 8 and 9].

Fig. 8: Obturating balloon colostomy -Torbay colosfony (from Ricketr 141).

Fig. 9. The device placed in the anastomoxis, showing ligatures around the outside of the colon (from Ricket (4)).
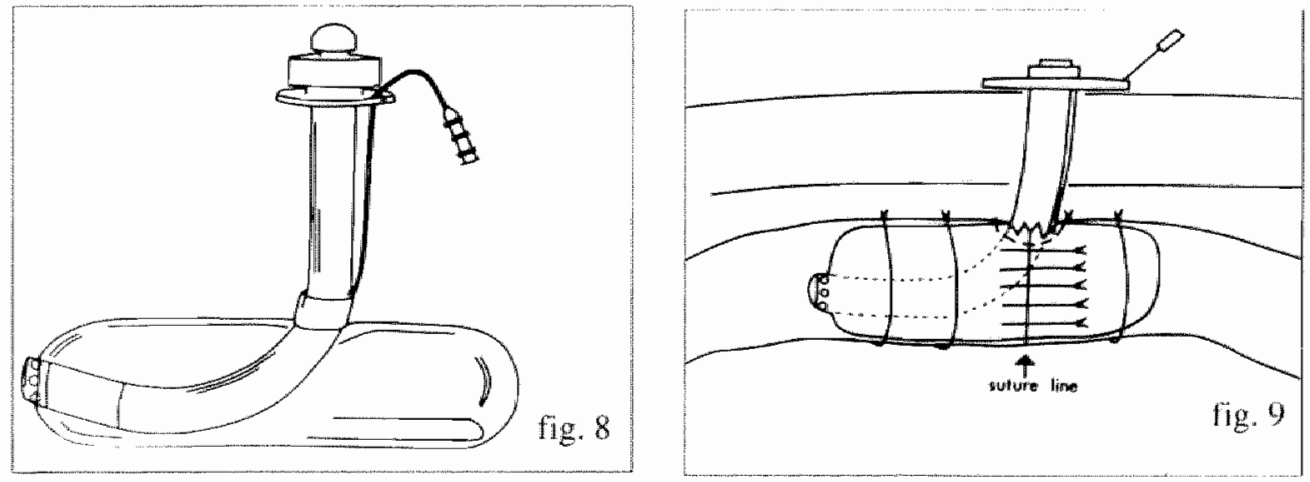

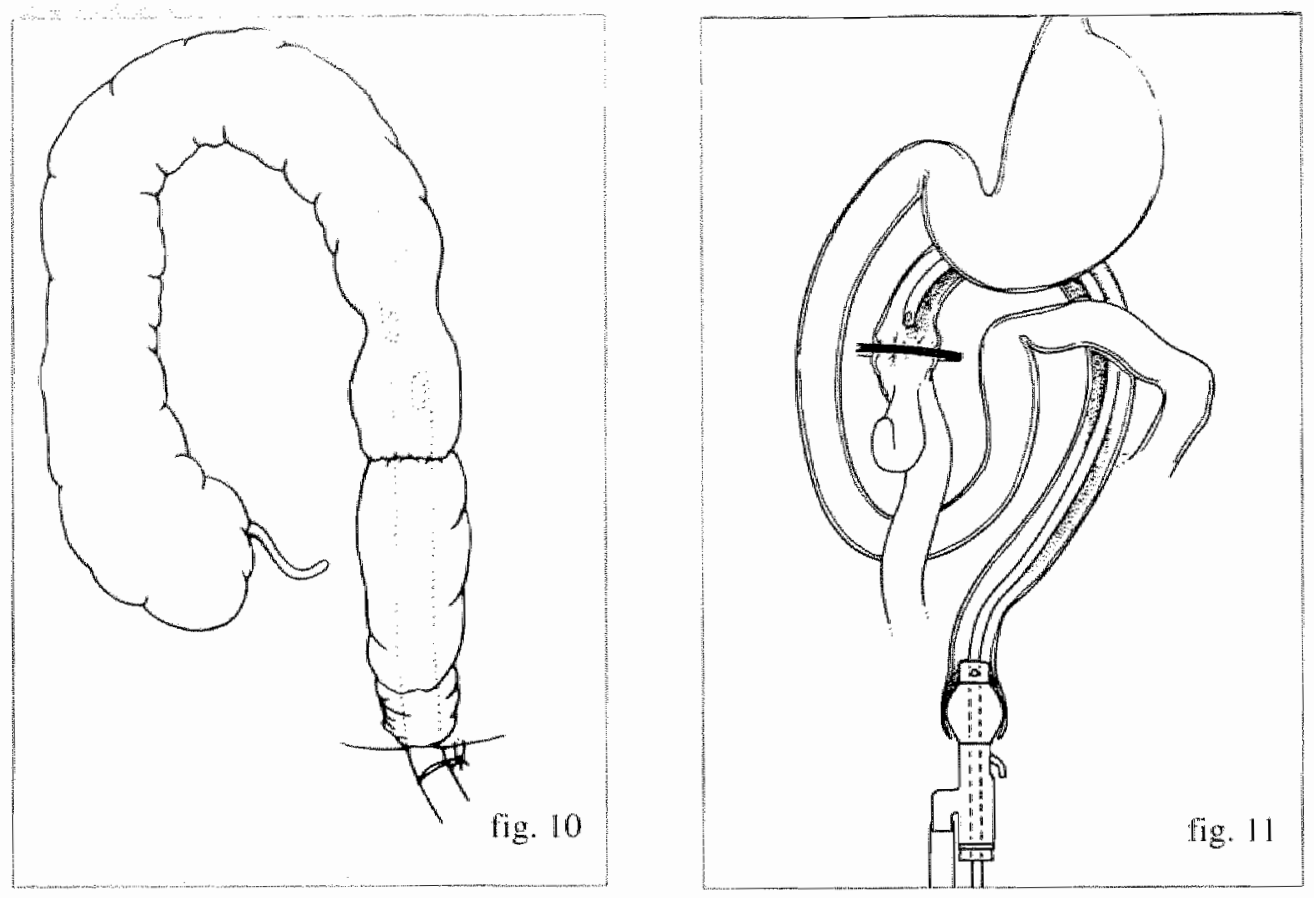

Fig. 10: Colonic tube to protecd the anastomosis after primary resection and anastomosis have been performed (from Hardy ef al. 15]).

Fig. 11: The method used for intraperative colonic cleansing in the experimental canine madel from Leiboff et al. (67).

When the lesion lay between the transverse colon and the mid sigmoid, the device was placed at the site of the anastomosis. When the lesion was distal to the mid sigmoid point and had been excised, the obturating balloon was placed proximally in the transverse colon in order to defunction the bowel distalty.

In the first case the device was removed after 7 days and in the latter case after $2-4$ weeks. Following removal of the device, the colostomy site, after initial faecal discharge, healed spontaneously in $1-3$ months.

Hardy et a. in 1985 [5]. at first performed a primary resection and anastomosis in the unprepatred bowel and therealter introduced a colon tube through the anastomosis to the proximal colon for irrigation. At the end of the irrigation, the tube was withdrawn to a point proximal to the anastomosis and fixed to the perianal skin [fig. 10].

Leiboflet al. in 1985 /6] experimentally employed specially designed irrigating instruments including a colonic tube and a balloon-ripped rectal tube with a wide diameter lumen through which the colonic tube could be passed. Irrigation fluid was instilled via the colonic tube using a pump and the effluent was led away through the rectal tube [fig. 11]. The method of antegrade intraoperative colon irrigation which has ganed wide use is Dudley's modification [7] of the irrigation procedure previously described by Windsberg and Muir. 


\section{Indications}

\section{Obstructions}

Intraoperative colon irrigation has mostly been employed to clean the colon either when there is an obstructing carcinoma of the left colon (because of which preoperative whole gut irrigation is not feasible), or in emergency colorectal surgery [7]. The procedure has also been used with other non-malignant left-sided obstructions (e.g. anastomotic stenosis).

\section{Diverticulitis}

This is the second most frequent indication for performing intraoperative colon irrigation and creating a primary anastomosis after resection.

\section{Non obstructing tumours}

The procedure is also employed in non-obstructing tumours of the left colon when preoperative bowel preparation is not possible or when the colon appears at operation to be ill-prepared. The use of the rectal tube in these cases will enable the procedure to carried out easily, without any spillage.

\section{Perforations}

In iatrogenic perforation (biopsies), traumatic wounds (gunshot; knife) or colonic perforation due to diverticulitis, intraoperative colon irrigation can easily be performed with the aid of the rectal tube after closing the perforation. After irrigation, resection and anastomosis can take place as in elective surgery.

The current management of civilian rectal injuries requires complete faecal diversion and presacral drainage of perirectal tissue to prevent fatal septic complications. The principles evolved from combat experience over the two World Wars and reduced the mortality of rectal wounds from $60 \%$ to approximately $20 \%$ during the Korean conflict $|8|$.

Operative rectosigmoid washout to remove faecal debris became standard during the Vietnam war to further reduce pelvic infection [9-12].

Although the value of this manoeuvre in managing civilian rectal wounds thas been questioned [13-27]. primary repair is supported more and more |28].

Shannon et al. [22] showed an increase of septic complications in civilian rectal trauma managed without a rectal washout compared with groups in which a distal rectal washout was performed.

With the intraoperative colon imigation technique, traumatic wounds of the left colon or rectum (gunshot, knife) can be managed safely as a one stage procedure.

After preliminary closure of the perforation, intraoperative colon irrigation and decontamination [see chapter 9] are performed with the aid of the rectal tube. Hereafter the closed perforation site is resected and anastomosed as a primary procedure in the optimally prepared colon. If closure of the perforation is not possible, colonic irrigation can take place using the irrigation drainage tube and rectal washout performed via the inbuilt irrigation canal of the specially designed rectal tube. 


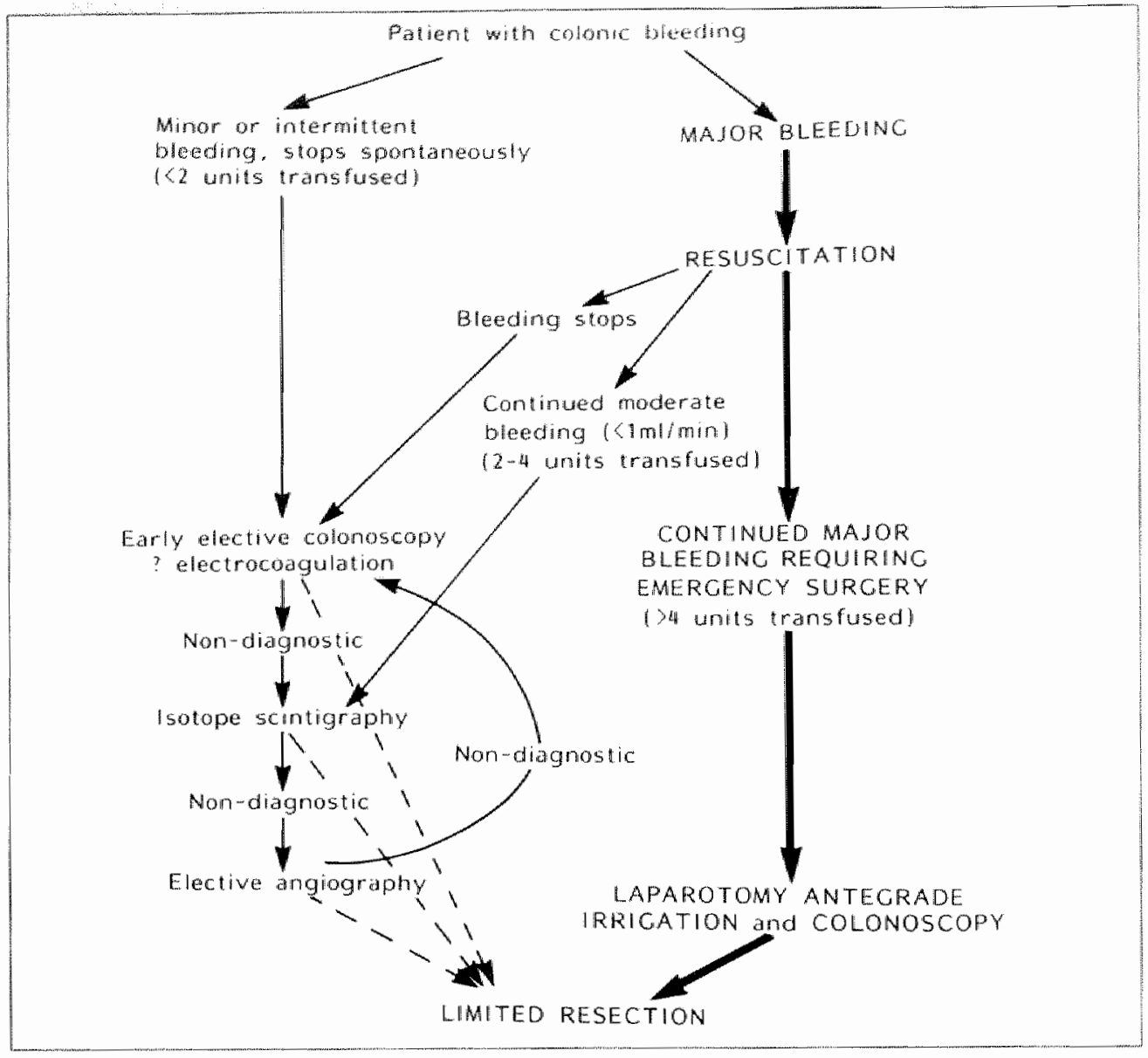

Fig. 12: Algorithm for the management of patients with major colonic hacmorrhage (from Berryer al. 1531$)$.

\section{Major colonic haemorrhage}

New indications for the use of intraoperative colon imigation have been reported $[29,30]$ in patients with major colonic bleeding in which the source is unclear despite the avaliability of modern diagnostic techniques such as selective angiography and isotope scintigraphy [3|-51]. In these patients [fig. 12], intraperative colon irrigation is performed during laparotomy using the rectal tube 153$]$.

Colonic irrigation in such patients has been reported 10 be quite rapid (within 10 minutes), during which time 3 litres of tluid are sufficient to ensure complete clearance of the colon [29]. After the imigation, the rectal tube is removed and a colonoscopy is then carried out by the endoscopist sitting between the legs of the patient (who lies in a Lloyd-Davies position). The passage of the colonoscope is assisted by the surgeon [fig. 13] who can also inspect the colon by transillumination. Localisation of the source of colonic bleeding is nearly always possible [53] and a partial colectomy, instead of the common blind (sub)total colectomy $[54,55]$ can then sately be performed. 


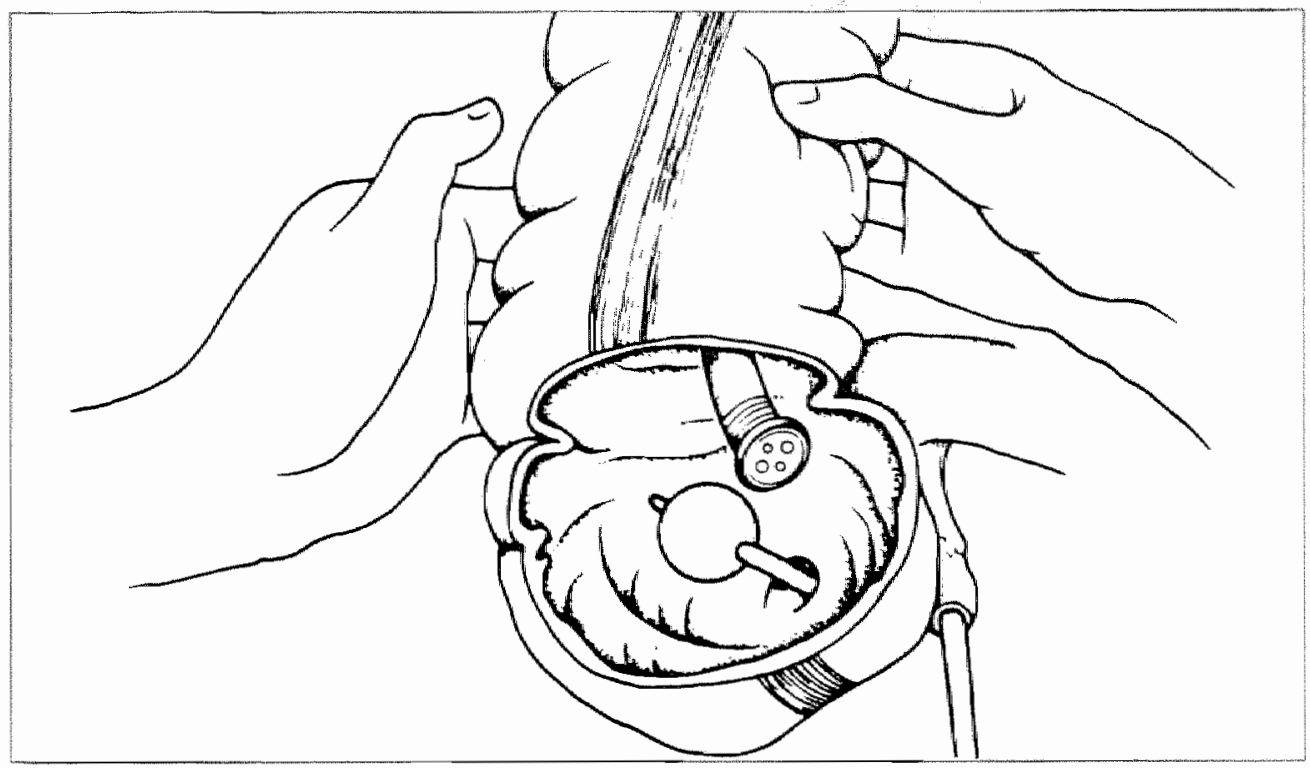

Fig. 13: Cut-away view of the caecal pole showing the Foley catheter inserted through the appendix and the colonoscope passed through the whole colon (from Scot at al. (30)).

\section{Fistulae}

In some patients with, for example rectovaginal fistulae there may be sone practical objections to preoperative whole gut irrigation or other bowel preparations. After closing of the fistula during laparotomy, intraoperative colon irrigation can be carried out, preferably using the rectal tube.

\section{Closure of a diverting colostomy}

A few patients with a diverting lefi-sided colostomy have undergone this procedure $|56|$. The reason for performing intraoperative colon irrigation is mostly the ill-prepared colon at operation.

\section{Volvulus}

Volvulus of the left colon which can not be treated conservatively [57] necessitates at laparotomy. At operation, a simple retorsion or colopexy can be done if the colon itself appears to be healthy. Volvulus of the sigmoid however is reported to have a high recurrence rate, which suggest that elective resection would frequently prove necessary in any case $[58-63]$.

With intraoperative colon irrigation, resection and primary andstomosis is feasiblle $[64 \mid$. 


\section{Contraindications}

It is not suggested that intraperative colon irrigation should be a routine procedure. Several factors pleading against the use of intraperative colon irrigation and primary anastomosis are: cardiopulmonary instability; poor general condition; deficient nutritional state and immunosuppression. Local factors (intra-abdominally) are: advanced peritonitis; interloop abcesses and unhealthy or poorly vascularised bowel ends at resection.

\section{Results in the literature}

A review of the results from 1980 to December 1988 17,29,56,64-9.70-3] using the intraoperative colon irrigation is listed in table 1 . The indications for which this method has been used are displayed in lable 2. Mortality due to anastomotic leakage is low, illustrating the safely of the method.

Table I: Resulvin in the world fiterature concerming intraoperatue colon irrigation.

\begin{tabular}{|c|c|c|c|c|c|c|}
\hline Author & Year & $\begin{array}{l}\text { No. of } \\
\text { patients }\end{array}$ & $\begin{array}{c}\text { Mean } \\
\text { age }\end{array}$ & $\begin{array}{l}\text { Anastom. } \\
\text { leakage }\end{array}$ & $\begin{array}{l}\text { Wound- } \\
\text { infect. }\end{array}$ & Deaths \\
\hline Dudley (D) & 1980 & 2 & 63 & - & - & - \\
\hline Radcliffe (R) & 1983 & 64 & $?$ & 2 & 5 & $2(1)^{*}$ \\
\hline Aideri (A) & 1985 & 24 & $?$ & 1 & - & $?(0)^{*}$ \\
\hline Koruth $(\mathrm{K})$ & 1985 & 61 & 74 & 4 & 2 & $5(1)^{*}$ \\
\hline Camploell (C) & 1985 & 4 & 49.5 & - & - & - \\
\hline Scott $(S)$ & 1986 & 4 & 56 & - & - & - \\
\hline Eggert (E) & 1986 & 9 & 71 & - & - & 1 \\
\hline Foster (Fo) & 1986 & 15 & 76 & 2 & 2 & 2 \\
\hline Mourik van (M) & 1986 & 15 & 70 & - & - & 3 \\
\hline Thomson (T) & 1986 & 126 & 67.2 & 6 & 4 & $5(2) *$ \\
\hline Pollock (P) & 1987 & 41 & 79 & - & $2(13)^{*}$ & $7(0)^{k}$ \\
\hline Feng $(F e)$ & 1987 & 5 & 61.8 & - & - & - \\
\hline Konishi (Kon) & 1988 & 25 & 61.1 & 1 & $\therefore$ & $1(1)^{*}$ \\
\hline Tolual & & 395 & 66.2 & $\begin{array}{c}16 \\
(4.1 \%)\end{array}$ & $\begin{array}{l}15 \\
(3.8 \%)\end{array}$ & $\begin{array}{l}26 \\
(6.6 \%)\end{array}$ \\
\hline
\end{tabular}

* dean due to anasomotic leakage

* 13 minor womd infertions 
Table 2: Indications for intraoperarive colon irrigation in the world litertare.

\begin{tabular}{|c|c|c|c|c|c|c|c|c|c|c|c|c|c|c|}
\hline \multirow[t]{2}{*}{ Diagnoses } & \multicolumn{9}{|c|}{ Authors } & \multicolumn{5}{|r|}{ Total } \\
\hline & D & $\mathrm{R}$ & A & $\mathrm{K}$ & $\mathrm{C}$ & $S$ & $\mathrm{E}$ & Fo & M & $\mathrm{T}$ & $P$ & $\mathrm{Fe}$ & Kon & $*$ \\
\hline Tumours(left colon) & 2 & 50 & 24 & 47 & & & 6 & 7 & 8 & 106 & 41 & 5 & 21 & 317 \\
\hline Diverticulitis & & 8 & & & & & 1 & 5 & & 13 & & & & 27 \\
\hline Perforation & & 2 & & 12 & & & 2 & & 2 & & & & & 18 \\
\hline Haemonthage & & & & 2 & 4 & 4 & & & 1 & & & & & $\|$ \\
\hline Closure of colostomy & & & & & & & & & 4 & & & & & 4 \\
\hline Volvulus & & 1 & & & & & & 3 & & & & & 4 & 8 \\
\hline Anastomotic stenosis & & 2 & & & & & & & & & & & & 2 \\
\hline Fistulae & & 1 & & & & & & & & & & & & 1 \\
\hline Others & & & & & & & & & & 7 & & & & 7 \\
\hline
\end{tabular}

$\begin{array}{lllllllllllllll}\text { Total } & 2 & 64 & 24 & 61 & 4 & 4 & 9 & 15 & 15 & 126 & 41 & 5 & 25 & 395\end{array}$

* for abbreviations of authors" names see table 1.

\section{References}

\section{Windsberg E, Providence RI.}

Intestinal obstruction of the distal colon due to malignancy: single-staged decompression. and resection.

Surgery $1959 ; 46: 305-18$

\section{Muir EG.}

Safety in colonic resection.

Proc R Soc Med 1968;61:401-8.

\section{Thow GB.}

Intraoperative Chaffin sump recto-colonic irnigation.

Dis Colon Rectum 1976:19:330-3.

\section{Rickett JW.}

New method of single-stage resection of unprepared left colon: preliminary communication. J R Soc Med 1979;72:192-4.

\section{Hardy TG Jr, Stewart WRC, Aguilar PS.}

Prevention of colostomy in partial colonic obstruction by intraoperative rectal tube irrigation. Dis Collon Rectum 1985;28:122-7.

\section{Leiboff AR, Crowley M, Spano L, Zito G, Dennis C.}

Intraoperative high-flow antegrade irrigation. A new bowel-cleansing system.

Dis Colon Rectum 1985;28:323-32. 


\section{Dudley HAF, Radcliffe AG, MeGeehan D.}

Intraoperative inigation of the colon to permit primary anastomosis.

Br J Surg 1980;67:80-1.

8. Nance $\mathrm{IC}$.

Injuries to the colon and rectum.

In: Mattox KL, Moore EE, Feliciano DV, eds: Trauma. Norwalk, Appleton-Lang, 1987.

9. Armstrong RG, Schmitt H.I, Patterson LT.

Combat wourids of the extraperitoneal rectum.

Surgery 1973:74:570 4.

10. Ganchrow MI, Lavenson GS, McNamara JJ.

Surgical management of traumatic injuries of the colon and rectum.

Arch Surg 1970; 100:515-20.

11. Luavenson GS, Cohen A.

Management of rectal injuries.

Am J Surg 1971; 122:225-30.

12. Lung JA, Turk RP, Miller RE.

Wounds of the rectum.

Ann Surg 1970; 172:985-90.

13. Bartizal JF, Boyd DR, Folk FA, et all.

A critical review of management of 392 colonic and rectal injuries.

Dis Collon Rectum 1974;17:3113-18.

14. Haas PA, Fox TA Jr.

Civilian injuries of the rectum and anus.

Dis Colon Rectum 1979;22:17-23.

15. Hughes L.E.

Penetrating injuries of the extraperitoneal rectum.

Br J Surg $4969 ; 56: 169-72$.

16. Josen AS, Ferrer JM Jr, Forde KA, Zikria BA.

Primary closure of civilian colorectal wounds.

Ann Surg 1972; 176:782-6.

\section{Maull KI, Sachatello CR, Ernst CB.}

The deep perineall laceration-An injury frequently associated with open pelvic fractures: A need for agressive surgical management. J Trauma 1977; 17:685-96.

18. Moreno C, Moore EE, Rosenberger A, Cleveland HC.

Hemorthage associated with major pelvic fracture: a multispecialty challenge.

J Trauma 1986:26:987-94. 


\section{Mucha P Jr, Farnell MB.}

Analysis of pelvic fracture management.

J Trauma 1984;24:379-86.

20. Richardson JD, Harty J, Amin M, Flint LM.

Open pelvic fractures.

J Trauma 1982;22:533-8.

21. Robertson HD, Ray JE, Ferrari BT, Gathright JB Jr.

Management of rectal trauma.

Surg Gynecol Obstet 1982;154:161-4.

\section{Shannon FL, Moore EE.}

Primary repair of the colon: when is it a safe alternative?

Surgery 1985;98:851-60.

23. Rothenberger D, Velasco R, Strate R, Fischer RP, Perry JF.

Open pelvic fracture: A lethal injury.

J Trauma 1978;18:184-7.

24. Strate RG, Grieco JG.

Blunt injury to the colon and rectum.

J Trauma 1983;23:384-8.

\section{Trunkey D, Hayes RJ, Shires GT.}

Management of rectal trauma.

J Trauma 1973;13:411-5.

26. Tuggle D, Huber P Jr.

Management of rectal trauma.

Am J Surg 1984;148:806-8.

\section{Wanebo HJ, Hunt TK, Mathewson C.}

Rectal injuries.

J Trauma 1969;9:721-2.

28. George SM Jr, Fabian TC, Mangiante EC. Colon trauma: further support for primary repair. Am J Surg 1988;1:16-20.

29. Campbell WB, Rhodes M, Kettlewell MG.

Colonoscopy following intraoperative lavage in the management of severe colonic bleeding. Ann R Coll Surg Engl 1985;67:290-2.

30. Scott HJ, Lane IF, Glynn MJ, et al.

Colonic haemorrhage: a technique for rapid intra-operative bowel preparation and colonoscopy.

Br J Surg 1986:73:390-1. 
31. Nath RL, Sequeira JC, Weitman AF, Birkett DH, Williams LF Jr.

Lower gastrointestinal bleding. Diagnostic approach and management conclusions.

Am I Surg 1981:141:478-81.

\section{Colacchio TA, Forde KA, Patsos TJ, Nunez D.}

Impact of modem diagnostic methods on the management of active rectal bleeding.

Ten year experience.

Am ISurg 1982;143:607-10.

\section{Smith JL.}

Approaches to the problem of lower gastrointestinal bleeding.

Compr Ther 1984;10:43-50.

\section{Baum S, Nusbaum M, Blakemore WS, Finkelstein AK.}

The preoperative radiographic demonstration of intra-abdominal bleeding from undetermined sites by percutaneous selective celiac and superior mesenteric arteriography. Surgery 1965;58:797-805.

35. Nusbaum M, Baum S, Blakemore WS, Finkelstein AK.

Demonstration of intra-abdominal bleeding by selective arteriography.

JAMA $1965 ; 191: 389-90$.

\section{Talman LA, Dixon DS, Gutierrex FE.}

Role of arteriography in rectal hemorhage due to arteriove nous malformations and diverticulosis.

Ann Surg 1979;190:203-13.

\section{Schobinger $R$, Blakman $G$, Lin RK.}

Operative intestinal arteriography.

Acta Radiol 1957:48:330-6.

\section{Margulis AR, Heinbecker P, Bernard HR.}

Operative mesenteric arteriography in the seanch for the site of bleeding in unexplained gastrointestinal hemorrhage.

Surgery 1960;48:534-9.

39. Hines JR, Stryker SJ, Neiman HL, et al.

Intraperative anglography in intestinal angiodysplasia.

Surg Gynecol Obstet 1981:152:453-60.

\section{Sabanathan S, Nag SB.}

Operative angiography in the management of massive rectal bleeding.

„R Coll Surg Edinb 1984;29:96-9.

\section{Athanasoulis CA, Moncure AC, Greenfield AJ, Ryan JA, Dodson TF.}

Intraperative localization of small bowel bleeding sites with combined use of angiographic methods and methylene blue injection.

Surgery 1980;87:77-84. 
42. Nusbaum M, Baum S, Blakemore WS.

Clinical experience with the diagnosis and management of gastrointestinal hemorrhage by selective mesenteric catheterisation.

Ann Surg 1969;170:506-14.

43. Athow AC, Sheppard L, Sibson DE.

Selective visceral angiography for unexplained acute gastrointestinal bleeding in a district general hospital.

Br J Surg 1985;72:120-2.

44. Bar AH, DeLaurentis DA, Parry CE, Keohane RB.

Angiography in the management of massive lower gastrointestinal tract hemorrhage.

Surg Gynecol Obstet 1980;150:226-8.

45. Alavi A, Dann RN, Baum S, Biery DN.

Scintigraphic detection of acute gastrointestinal bleeding.

Radiology 1977; 124:753-6.

46. Flickinger FW.

Location of active lower gastrointestinal bleeding by technetium-99m sulfur colloid scan.

J Nucl Med 1981;22:38-9.

47. Miskowiak J, Nielson SL, Munck O, Burcharth F, Blichert-Toft M, Nadel MS.

Acute gastrointestinal bleeding detected with abdominal scintigraphy using

technnetium-99m-labelled albumin.

Scand J Gastroenterol 1979;14:389-94.

48. Winzelberg GG, Froelich JW, McKusick KA, Strauss HW.

Scintigraphic detection of gastrointestinal bleeding: a review of current methods.

Am J Gastroenterol 1983;78:324-7.

49. Olsen PR, Nielsen L, Dyrbye M, Hansen LK.

Colorectal bleeding localised with gamma camera.

Acta Chir Scand 1983;149:793-5.

50. Gupta S, Luna E, Kingsley S, Prince M, Herrera N.

Detection of gastrointestinal bleeding by radionuclide scintigraphy.

Am J Gastroenterol 1984;79:26-31.

51. Kester RR, Welch JP, Sziklas JP.

The $99 \mathrm{mTc}$-labelled red blood cell scan. A diagnostic method for lower gastrointestinal bleeding.

Dis Colon Rectum 1984:27:47-52.

\section{Cussons PD, Fletcher EWL, Berry AR.}

A comparison of the value of mesenteric angiography and on-table colonoscopy in massive acute large bowel haemorrhage.

Gut 1988;29:A727. 
53. Berry AR, Campbell WB, Kettlewell MGW.

Management of major colonic haemorrhage.

Br J Surg 1988;75:637-40.

54. Drapanas T, Pennington DG, Kappelman M, Lindsey ES.

Emergency subtotal colectomy: preferred approach to the management of massively bleeding diverticular disease.

Ann Surg 1973;177:519-26.

\section{Eaton AC.}

Emergency surgery for acute colonic haemorrhage- a retrospective study.

BrJ Surg 1981;68:109-12.

\section{Mourik JB van, Meijer S, Hoitsma HF.}

Antegrade lavage tijdens operatie van afwijkingen in het linker deel van het colon.

Ned Tijdschr Geneeskd 1986;130:1322-4.

\section{Schagen van Leeuwen J.}

Antegrade lavage tijdens operatie van afwijkingen in het linker deel van het colon.

Ned Tijdschr Geneeskd 1986;130:2191.

\section{Ballantyne GH, Brandner MD, Beart RW Jr, Ilstrup DM.}

Volvulus of the colon. Incidence and mortality.

Ann Surg 1985;202:83-92.

\section{Markel MD, Dreyfuss DJ, Meagher DM.}

Colopexy of the equine large colon: comparison of two techniques.

J Am Vet Med Assoc 1988;192:354-7.

\section{Mishra SB, Sahoo KP.}

Primary resection and anastomosis for volvulus of sigmoid colon.

J Indian Med Assoc 1986;84:265-8.

\section{Sharon N, Efrat Y, Charuzi I.}

A new operative approach to volvulus of the sigmoid colon.

Surg Gynecol Obstet 1985;161:483-4.

\section{Vasudevan S.}

Volvulus of sigmoid colon.

Trop Doct 1985;15:144.

\section{Welch GH, Anderson JR.}

Acute volvulus of the sigmoid colon.

World J Surg 1987;11:258-62.

\section{Radcliffe AG, Dudley HA.}

Intraoperative antegrade irrigation of the large intestine.

Surg Gynecol Obstet 1983;156:721-3. 
65. Alderi $G$, Perego P, Bugatti $A, B$ rivio $F$.

Die Anastomose bei notfallmässigen Dickdarmresektionen in der Therapie des obturierenden Kollonkarzinoms.

Zentralbl Chir 1985;110:112-9.

66. Koruth NM, Krukowski ZH, Youngson GG, et al.

Intra-operative colonic irrigation in the management of left-sided large bowel emergencies.

Br J Surg 1985;72:708-11.

67. Scott HJ, Lane IF, Glynn MJ, et al.

Colonic haemorrhage: a technique for rapid intra-operative bowel preparation and colonoscopy.

Br J Surg 1986;73:390-1.

68. Eggert A, Luetkens S.

Die intraoperative orthograde Darmspiilung. Zur Taktik bei colonchirurgischen Notfüllen.

Chirurg 1986;57:236-40.

69. Foster ME, Johnson CD, Billings PJ, Davies PW, Leaper DJ.

Intraperative antegrade lavage and anastomotic healing in acute colonic obstruction.

Dis Colon Rectum 1986:29:255-9.

\section{Thomson WH, Carter SS.}

On-table lavage to achieve safe restorative rectal and emergency left colonic resection without covering colostomy.

Br J Surg 1986;73:61-3.

\section{Pollock AV, Playforth MJ, Evans M.}

Peroperative lavage of the obstructed lefi colon to allow safe primary anastomosis.

Dis Colon Rectum 1987;30:171-3.

\section{Feng YS, Hsu H, Chen SS.}

One-stage operation for obstructing carcinomas of the left colon and rectum.

Dis Colon Rectum 1987:30:29-32.

\section{Konishi F, Muto T, Kanazawa K, Morioka Y.}

Intraoperative irrigation and primary resection for obstructing lesions of the colon.

Int J Color Dis 1988:3:204-6 


\section{Part II}

Clinical studies 


\section{Chapter 4}

\section{Prophylactic antimicrobials and whole gut irrigation in elective colorectal surgery: a prospective randomised study}

\section{Introduction}

Elective colon and, especially, rectal surgery is associated with a high incidence of postoperative septic complications. Most infections are endogenous and caused by dissemination of intestinal contents, either at the time of operation or as a result of anastomotic leakage [1]. It has been demonstrated that microorganisms spilled while the anastomosis is being created are able to destroy the anastomosis [1-3]. For this reason, optimal bowel preparation is mandatory and can be achieved either by a low residue diet with laxatives for several days, or by whole gut irrigation which takes only a few hours.

Neither conventional bowel preparation [4-7] nor whole gut irrigation reduce the intramucosal flora of the colon, although they both reduce the faecal mass and the total number of intraluminal bacteria. An anti-infectious effect of whole gut irrigation alone is never to be expected $[8-11]$.

Addition of antibiotics, either to minimise the concentration of bacteria in the colon or to achieve optimal serum and tissue levels at operation, is necessary and is common practice nowadays in elective colorectal surgery [12]. There are still controversies concening the choice of drugs and the dosages and methods of administration.

Although prophylaxis against the anaerobic flora alone has been shown to be effective [13$|6|$, it is generally accepted that any prophylaxis in elective colorectal surgery should cover both the acrobic and the anaerobic flora [17-23]. Both oral and parenteral administration of antibiotics have proved to be adequate for this $[24-29]$.

The pupose of the present study was to evaluate the results of various antimicrobial regimens combined with whole gut irrigation and to make the best choice for use in our hospital.

\section{Patients and methods}

All patients admitted for elective colorectal surgery from July 1979 to December 1983 were divided at random into thee groups. Each group underwent a bowel preparation (whole gut irrigation), but differed in the antibiotic used. The random code was broken and the study was stopped after 4.5 years by the independent observer because the complication rates in two groups appeared to be unacceptably high compared with the other group. Analysis of the results showed that reliable conclusions from this study could be drawn. Patients with severe cardiac decompensation, renal insufficiency and obstructing tumours were not given whole gut irrigation and were therefore excluded from this study. Patients 
with obstructing tumours received conventional bowel preparation or intraoperative colon irrigation [30]. Patients with ulcerative colitis or Crohn's disease and those admitted for emergency surgery were also excluded. Operations for closure of colostomies were not included.

All patients received the whole gut irrigation as described by Hewitt et al. [31] and Crapp et al. [32] on the day before operation. A nasogastric tube was placed in the stomach with the patient in a sitting position. The irrigant was warmed to $37^{\circ} \mathrm{C}$ with the help of a hemoheater. The bowel was irrigated under nursing supervision at a speed of 3 to 4 litres/hour until at least 10 litres had been given or the effluent was totally clear. To prevent symptoms of nausea, vomiting and distention, $10 \mathrm{mg}$ meclopramide was given intramuscularly or intravenously to all patients prior to the irrigation and was repeated during the lavage procedure when necessary.

\section{Prophylactic regimens}

Three groups were formed and each patient was allocated to a particular group by drawing from a randomised sealed envelope a card which defined the prophylactic regimen to be used (table 1). The first group received $250 \mathrm{mg}$ of oxytetracycline intravenously with the premedication and this drug was continued once daily for 5 days after the operation. This was the standard policy in elective colorectal surgery at that time and it was included in the trial.

Table 1: Antibiotic regimens of this study.

Group 1

(O)

Whole gut irrigation

oxytetracycline $250 \mathrm{mg}$ iv. at premedication

oxyterracycline $250 \mathrm{mg}$ im. once daily for 5 days

Group 2

Whole gut irrigation

(T-M)

metronidazole $2 \mathrm{~g} / \mathrm{oral}$ after WGI

tobramycin $1.5 \mathrm{mg} / \mathrm{kg}$ iv with induction of anaesthesia

tobramycin repeated 8 and 16 hours post operatively

if operation $>3$ hours

Group 3

Whole gut irrigation

(N-M)

neomycin $1 \mathrm{~g} / \mathrm{litre}$ and metronidazole $0.5 \mathrm{~g} / \mathrm{l}$ in the irrigation fluid from 6th litre onwards. 
The second group received 2 grams of oral metronidazole after the whole gut irrigation but 12 hours before operation, followed the next day by tobramycin $1.5 \mathrm{mg} / \mathrm{kg}$ intravenously with the induction of anaesthesia. If the operation lasted for more than three hours, vobramycin was given at eight and sixteen hours posioperatively.

The third group received only neomycin $(1 \mathrm{~g} / 1)$ with metronidazole $(0.5 \mathrm{~g} / \mathrm{l})$ in the irrigation fluid from the 6 th litre onwards. All patients were irrigated with at least 10 litres, so every patient neceived at least 2.5 grams metronidazole and 5 grams of neomycin.

\section{Exclusion after admission to trial}

The number of patients entering the trial was 239 . A total of 27 patients were excluded, 10 because no colon surgery was performed. Six patients were given other antibiotics 48 hours prior to surgery. The whole gut irrigation procedure had to be stopped in eight parients because of vomiting and in three patients because of collapse (table 2 ).

Table 2: Patient selection and reason for exclusion

No. of patients

Entering the study

Excluded

Reasons for exclusion:

No colon surgery performed

Other antibiotic used

WGI stopped because of:
a. vomiting
b. collapse
8
3

\section{Observations}

The wound was examined on the third and seventh days and on the day of discharge, by a resident unaware which prophylactive regimen had been followed. The last wound inspection took place at the first outpatient clinic visit, mostly four to six weeks after discharge. In the presence of wound infection aerobic and anaerobic cultures were taken. Blood cultures were taken when there were clinical grounds for suspecting septicaemia. 


\section{Colonic bacterial counts at operation}

The bacterial flora in the groups were compared in 50 patients by taking swabs of the colon lumen at the proximal resection site during operation just before the performance of the anastomosis. $E$. coll and $B$. fragilis were counted and expressed as $\log 10$ of the colon counts per ml.

\section{Bacteriological methods}

Swabs of colon contents and cultures from infected wounds were placed in Stuarts transport medium in $4 \mathrm{ml}$ bijou bottles and fluid specimens were used to fill up other small screw-capped vials. All samples were taken without delay to the laboratory where they were cultured on the following media: sheep blood agar, Sabouraud agar and MacConkey agar plates (incubated in air), lysed sheep blood agar with Butzler's campylobacter supplement (incubated in a mixture containing $5 \% \mathrm{O}_{2}, 10 \% \mathrm{CO}_{2}$ and $85 \% \mathrm{~N}_{2}$ ), and supplemented anaerobic sheep blood agar containing $50 \mathrm{mg} / \mathrm{l}$ kanamycin, supplemented anaerobic horse blood agar (with nalidixic acid and Tween 80). All anaerobic cultures were incubated at $37^{\circ} \mathrm{C}$ in an anaerobic cabinet (Forma Scientific, USA) in an atmosphere of $85 \% \mathrm{~N}_{2}, 10 \% \mathrm{CO}_{2}$ and $5 \% \mathrm{H}_{2}$

\section{Definitions}

Severe wound $(S)$ infection: Wound infection was defined as severe in the presence of pus in the incision, often followed by further opening and drainage of the wound. Wounds opened on clinical grounds and containing pus were also allocated to this group.

Moderate wound (M) infection: Wound infection was regarded as moderate in the presence of erythema, painful induration or secretion with or without a positive culture. In this case hardly any surgical intervention was necessary to promote wound healing and no prolongation of hospitalisation or rehospitalisation was required.

Sepricaemia was considered to be present only if micro organisms could be cultured from the blood.

In a high anterior resection the entire operation was conducted above the level of the pelvic peritoneal floor, the rectum itself was not mobilised, and the final anastomosis was between colon and a stump of upper rectum possessing at surrounding cuff of peritoneum.

In a low anterior resection the pelvic peritoneum was opened, the lateral rectal ligaments were divided and the rectum was lifted out of its sacral bed. The distal line of resection traversed the extraperitoneal rectum and the final anastomosis was between the sigmoid or descending colon and a low rectal stump without a peritoneal coat.

\section{Operative procedure}

The patients were operated on either by residents supervised by attending surgeons or by one of the senior surgeons themselves. All anastomoses were performed in two layers, with an inner continuous chromic catgut layer and an outer layer of knotted inverting VicrylR, except for the anterior resections where either a one layer continuous running suture of 
chromic catgut or the Stapler apparatus was used. The anastomosis was covered with an omental flap whenever possible.

In low anterior resections two suction drains below the peritoneal reflections were used and brought out througlin separate stab wounds. In low anterior resections at least a catheter caecostomy was placed unless the surgeon felt that a diverting colostomy was necessary. The abdominal wound was closed in layers using knotted Vicry $\mathbb{R}^{R}$ or running monofilament VicrylR (PDS) for the lascia, the subcutis was not drained as a rule and was closed if necessary with knotted VicrylR. The skin was closed either by intracutaneous running monofilamentous VicrylR (PDS) or by knotted nylon. After abdomino-perineal resection of the rectum the proctectomy space was closed as a primary procedure over a sump drain, either placing omentum in the space or restoring the walls with peritoneum without creating an empty space.

All leftsided anastomoses were investigated on the loth postoperative day with a gastrographin enema. Anastomotic leakages were divided into clinical, radiographical and radiographical plus clinical. The leakage was radiographical and clinical when symptoms of leakage occurred after the $X$-ray.

\section{Statistics}

Results were analysed using the $X^{2}$ test and the Student's t-test for small numbers, with the Rang test for comparing the duration of hospital stay.

\section{Results}

\section{Patient population}

The mean age, sex, preoperative diagnosis and the type of surgery performed in the several groups were comparable and showed no statistical differences (tables $3,4,5$ ).

Table 3: Age: Sex distribution.

\begin{tabular}{lrrrr} 
& Group 1 & Group 2 & Group 3 & Total \\
\hline Age <30: & 2 & 1 & 2 & 5 \\
$31-40:$ & 3 & 2 & 3 & 8 \\
$41-50:$ & 6 & 5 & 9 & 20 \\
$51-60:$ & 13 & 19 & 16 & 48 \\
$>60:$ & 48 & 43 & 40 & 212 \\
\hline Total no. pat. & 72 & 70 & 70 & 99 \\
\hline Male: & 34 & 34 & 31 & \\
\hline Mean hospital stay (days) & & & & \\
a. uncomplicated & 22.5 & 22.3 & 22.7 & 24.8 \\
b. complicated & 46.7 & 43.8 & & \\
\hline
\end{tabular}


Table 4: Comparison of the diagnosis.

\begin{tabular}{lrrrr}
\hline Diagnosis & $\begin{array}{r}\text { Gp1 } \\
(\mathrm{O})\end{array}$ & $\begin{array}{r}\text { Gp2 } \\
(\mathrm{T}-\mathrm{M})\end{array}$ & $\begin{array}{r}\text { Gp3 } \\
(\mathrm{N}-\mathrm{M})\end{array}$ & Total \\
\hline Carcinoma of caecum/asc. colon & 13 & 16 & 10 & 39 \\
Carcinoma of transverse colon & 5 & 5 & 6 & 16 \\
Carcinoma of desc. colon & 5 & 3 & 4 & 12 \\
Carcinoma of sigmoid & 15 & 10 & 12 & 37 \\
Carcinoma of rectum & 19 & 18 & 18 & 55 \\
Sigmoid diverticulosis & 10 & 13 & 13 & 36 \\
Miscellaneous & 5 & 5 & 7 & 17 \\
\hline Total number of patients & 72 & 70 & 70 & 212 \\
\end{tabular}

Table 5: Comparison of the operations.

\begin{tabular}{lrrrr}
\hline Operations & $\begin{array}{r}\text { Gp1 } \\
(\mathrm{O})\end{array}$ & $\begin{array}{r}\text { Gp2 } \\
(\mathrm{T}-\mathrm{M})\end{array}$ & $\begin{array}{r}\text { Gp3 } \\
(\mathrm{N}-\mathrm{M})\end{array}$ & Total \\
\hline Right hemicolectomy & 13 & 16 & 10 & 39 \\
Transv. colon resection & 5 & 5 & 6 & 16 \\
Left hemicolectomy & 5 & 3 & 4 & 12 \\
Sigmoid resection & 12 & 8 & 7 & 27 \\
Anterior resection & 25 & 23 & 26 & 74 \\
Abdomino-perineal resection & 7 & 10 & 10 & 27 \\
Miscellaneous & 5 & 5 & 7 & 17 \\
\hline Total & 72 & 70 & 70 & 212 \\
\hline
\end{tabular}

Although more than $90 \%$ of the patients were older than 50 years, only in $5 \%$ (11 patienis) did the whole gut irrigation procedure have to be stopped.

The procedure was well tolerated and the degree of emptiness of the colon was excellent to good in more than $90 \%$ of the patients. Postoperative wound infections after the warious operations are listed in tables 6,7 and 8 together with the organisms cultured.

\section{Bacteriological results}

The results of the intraoperative colonic bacterial counts are shown in figure I (page 56). In group 3 (where neomycin and metronidazole had been used in the irrigation fluid), a highly significant reduction of E. coli $(\mathrm{p}<0.001)$ and B. fragilis $(\mathrm{p}<0.002)$ occurred compared with group 1. Due to the small numbers of cultures in group 2 statistical comparison with group 3 is not adequately possible. 


\section{Wound infections}

Wound infections in the group receiving oxytetracycline (table 6) were mostly caused by Escherichia colt and Bacteroides fragilss. Hardly any Staphyloccocus aureus were cultured. In the second group receiving tobramycin and metronidazole (table 7) aerobic organisms (E. coll) were still often cultured from many wound infections, but the anaerobic bacteria (B. fragilis) were seldom present and could be found only in 3 cases. In the third group (table 8) anaerobic infections were abolished, and only in two patients were abdominal infections present, caused by aerobic bacteria. In all three groups, the perineal wound infection rate was high and in the third group (exogenous) Staph. aureus was often found.

A dramatic reduction of abdominal wound infection in group $3(3.3 \%)$ occurred (table 9 ) when compared with group $\mathbb{\|}(\mathrm{p}<0.002)$ and also when compared with group $2(\mathrm{p}<0.03)$. No significant differences in perineal wound infection could be found, but because of the small numbers undergoing abdomino-perineal resections no conclusions could be drawn.

Table 6: Wound infections in group I related to the type of operation and organisms. cullured.

Organism cultured

Type of resection

Type of infection

Aerobe

Anaerobe

1. sigmoid

2. sigmoid

3. sigmoid

4. sigmoid

5. abd.-perineal

6. sigmoid

7. hemicolectomy R.

8. hemicolectomy R.

9. anterior

10. hemicolectomy $R$.

11. abd.-perineal

12. hemicolectomy $\mathrm{L}$.

13. anterior

14. hemicolectomy L.

15. anterior

16. abd.-perineal abd. (S)

abd. (M)

abd. (M)

abd. (M)

abd.tperineal (S)

abd. (S)

abd. (S)

abd. (M)

abd, (M)

abd. (S)

perineal (S)

abd. (M)

abd. (S)

abd. (S)

abd. (S)

perineal (S).
E. coli; Strept faec.

E. coli; Strept faec.

P. mirabilis

Strept. faec.

E. coli

B. frag.

-.w.

E. coli

E. coli, P. mirabilis

-...-

Strept. sanguis

P. mirabilis

E. coll strep faec.

E. coll; P. mirabilis

E.coli

E. coli
B. frag.

B.fiag.

B. frag.

B. frag.

-...-

B. frag.

-....

$\cdots$

$\ldots$

B. frag.

B. frag.
B. frag.

$S=$ severe, $M=$ moderate infections 
Table 7: Wound infections in group 2 related ro the rype of openation and organisws cullured.

Organism cultured

Type of resection

Type of infection

Aerobe

Anaerobe

1. partial colectomy

abd. (M).

2. colotomy

abd. (M).

3. hemicolectomy $\mathrm{R}$.

abd. (M).

4. abd.-perineal

perineal $(S)$.

perineal $(S)$.

E. coll: P. mabilis

P. mirab. Strept.

6. abd.-perined

abd. (M).

E. coll; P. minabilis

7. abd-perineal

abd.t perineal (S).

8. sigmoid

abd. (S)

9. sigmoid

10. abd.-perineal

abd. (M)

11. anterior

perineal $(\mathrm{S})$

abd. (M)

12. abd--perineal

perineal (M)

E. coli

E. coli; P. mirabilis

-

13. anterior

abd. (M)

14. sigmoid

abd. (M)

15. transv.colon

abd. (M)

Staph aureus.

16. anterior

abd. (M)

17. hemicolectomy $\mathrm{R}$.

abd. (M)

Staph aureus.

B. frag.

B. $f \mathrm{rg}$.

……

B. frag.

Strept pyogenes.

E. coll: Haem. strept.

E. colt; Strept agalact

Staph aureus

E. coli.

Staph. aureus

Table 8: Wound infections in group 3 related to the type of aperation and organisms cultured.

\section{Organism cultured}

Type of resection

Type of infection

Aerobe

Anaerobe

1. abd.-perineal

2. abd-perineal

3. abd.-perineal

4. sigmoid perineal (M)

perineal+abd. (S)

perineal (M)

abd. (S)
Staph aureus: P. mirab.

Shaph. aureas:"

E. call; P. mirab.

Staph. aureus

Strept face. 
Table 9: Postoperative septic complications in the different groups.

$\begin{array}{llll}\text { Results } & \text { Group } 1 & \text { Group } 2 & \text { Group } 3 \\ & (\mathrm{O}) & (\mathrm{T}-\mathrm{M}) & (\mathrm{N}-\mathrm{M})\end{array}$

\begin{tabular}{|c|c|c|c|}
\hline Number of patients $(N=212)$ & 72 & 70 & 70 \\
\hline Abdominal wound infection $(\%)[W]$ & $14 / 72(19.4)$ & $13 / 70(18.6)$ & $2 / 70(2.9)$ \\
\hline Perincal wound infection (\%) & $3 / 7(42.9)$ & $5 / 10(50)$ & $3 / 10(30)$ \\
\hline Overall anastomotic leakage $(\%) \mid L]$ & $14 / 65(21.5)$ & $10 / 60(16.7)$ & $2 / 60(3.3)$ \\
\hline Septicaemia $(\%)$ & $8 / 72(11.1)$ & $6 / 70(8.6)$ & $0 / 70(0)$ \\
\hline
\end{tabular}

\begin{tabular}{|c|c|c|}
\hline$W 1: W 2 \quad p>0.05$ & $L 1: L 2 \quad p>0.05$ & $\mathrm{~S} 1: \mathrm{S} 2 \mathrm{p}>0.05$ \\
\hline W2: W3 $p<0.003$ & $L 2: L 3 \quad p<0.02$ & $\mathrm{S2}: \mathrm{S3} p<0.02$ \\
\hline W3: W] $p<0.002$ & L3: L1 $p<0.002$ & S3:S1 $p<0.004$ \\
\hline
\end{tabular}

\section{Anastomotic leakage}

The overall (clinical and radiological) anastomotic leakage rate in patients in whom a colocolonic anastomosis was made (thereby excluding abdomino-perineal resections ) was $14 \%$ in group $1.10 \%$ in group 2 and $3.3 \%$ in group 3 . The leakage rate in group 3 was much lower in comparison with group $1(\mathrm{p}<0.002)$ and was also significantly reduced when compared with group $2(\rho<0.02)$.

\section{Septicaemia}

Septicamia occurred in 8 patients in group 1 from whom aerobic organisms (moslly $E$. coli) as well as anaerobes were culured. In the second group, septicaenia was only caused by aerobic bacteria and no anaerobes were cultured from the bloodstream. No septicamia all all was observed in the third group. Statistically significant differences between groups 1 and 2 were not present.

\section{Seriousness of wound infection and anastomotic leakage}

Statistical significance hardly says anything about the gravity of a complication. In order to study their setiousness. wound infections and anastomic leakages were subdivided. In group 1 seven patients had only wound infections, one patient had a wound infection and anastomotic leakage and wo patients had a wound infection and septicaemia. Furthermore, 
six patients had wound infections combined with anastomotic leakage and septicaemiat (rable 10). Most wound infections were severe, affecting the whole depth of the skin and. as shown in table 10, were accompanied by several other serious complications.

In the third group only four patients developed wound infections and they had no other accompanying complications.

Subdividing the anastomotic leakages (table 11) shows clearly that in groups 1 (7 patients) and 2 ( 4 patients) severe leakage occurred, whereas only two patients in group 3 had radiologically demonstrable leakages without clinical consequences.

Table 10: Wound infection and other complications.

Gp $1 \quad$ Gp $2 \quad$ Gp 3

Wound infection alone 7

94

Wound infection together with:

- anastomotic leakage

- septicaemia

- anastomotic leakage and septicaemia

1

2

6

30

20

30

Total number of patients:

16

17

4

Table 11: Anastomotic leakage subdivided.

Gp 1 Gp 2 Gp3

Anastonotic leakages (total number of patients) $\quad 14$

Radiological leakage

Clinical leakage

Clinical and radiological leakage 


\section{Mortality}

Three patients in the group receiving oxytetracycline died of septic complications $(5 \%)$. and two patients in the group receiving metronidazole and tobramycin died. All these patients had disruption of the anastomosis with intra-abdominal abcess formation. Bacteroides fragilis and E. coli were cultured from the bloodstream most often in the first group; in the second group all cases of septicaemia were caused by aerobic organisms. No death due to septic complications was noticed in the third group.

\section{Postoperative hospital stay}

The mean hospital stay (table 3 ) in the uncomplicated cases was comparable in the different groups. However, if complications occurred the hospital stay was doubled in the first two groups but was hardly influenced at all in the third one. This is of clinical importance although the hospital stay in group 3 just failed to reach a significant difference for $p<0.05$ compared with the other groups.

\section{Anterior resections}

The percentage of patients with anterior resections who develop anastomotic leakage is known to be high and is associated with a high morbidity and a particularly high mortality [33]. In the present study all anterior resection anastomoses were investigated by a gastrographin enema on the 10 th day. In the third group only two patients $(2 / 26=7.7 \%)$ with low anterior resections had radiological signs of leakage in the absence of any clinical signs, whereas in groups 1 and 2 the leakage rates were $36 \%(9 / 25)$ and $26 \%(6 / 23)$ (table 12).

Table 12: Anastomotic leakage in patients with anterior resections $(N=74)$

\begin{tabular}{lccccc} 
Gromp & High & Low & N & Leakage & \%leaks \\
\hline 1 (O) & 19 & 6 & 25 & 9 & 36 \\
$2($ T-M $)$ & 12 & 11 & 23 & 6 & 26 \\
$3(\mathrm{~N}-\mathrm{M})$ & 14 & 12 & 26 & 2 & 7.7 \\
\hline
\end{tabular}

$1: 2 p>0.05$

$2: 3 p=0.09$

$3: 1 \mathrm{p}<0.02$ 


\section{Prospective study group 1984-87}

After finishing this trial we decided to use the regimen of group 3 (neomycin and netronidazole in the imigation fluid) for all patients who were admitted for clective colorectal surgery in this hospital and who matched the criteria of the mal. All patients admitted from January 1984 to December 1987 were studied prospectively. The patients operated on $(n=215)$ had all been admitted with carcinoma of the colon except for 31 patients who had diverticulosis and 14 patients operated for benign lesions (adenoma; (istula). The data collected from these patients once more confimed the results of group 3 in the trial (tables 13 and 14 ).

Table 13: Diagnosis of patients admitted for elective colorectal surgery from 1984-87. undergoing whole gut imigation and fulfilling the criteria for the trial.

Diagnosis

number of patients

carcinoma of caecum/ascending colon

carcinoma of transverse/descending colon

8

diverticulosis

31

carcinoma of sigmoid

37

carcinoma of rectum

78

miscellaneous

14

Total

Table 14: Elective colorectal operations from 1984-87 after whole gut irrigation with neomycin and metronidazole in the irrigation fluid and fulfilling criteria for the trial.

Type of resection

Pat.

Infection

abd. perin.
Leakage

radiol. clin. hemicolectomy $\mathrm{R}$. transverse colon and hemicolectomy L. sigmoid anterion:-high low abd.-perineal

\section{1} 16 35 26 62 25
2

$\begin{array}{lll}1 & & \\ 1 & & \\ 2 & & \\ & 8 & \end{array}$

$6(2.8 \%) \quad 8(32 \%)$

$4(2.1 \%) \quad 1(0.5 \%)$

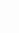


Three radiographical leakages occurred and wo patients had clinical evidence of leakage. The first patient had undergone left hemicolectomy in the past and was admited again with a rectal carcinoma. After resection of the tumour the continuity of the bowel could only be restored by the interposition of an ileal loop. A clinical leakage occurred without mound infection or septicamia. The second patient with symptoms of clinical leakage lad been operated on for a "simple" excision of a polyp via a sigmoidotomy.

Eight moderate perineall wound infections $(30 \%)$ were noticed, twice caused by Staph. aume and twice by $E$. colt. Although no significant prolongation of the hospital stay occurred, it still has to be noted that the number of perineal infections was high (8 out of 25 rectum amputations). It is however comparable with the results of other workers [19. 34$]$ who used the same definitions of wound infection and kept a prospective survellance for its occurrence. Bacteroides fragilis was totally abolished and was never cullured from infected abdominal or perineal wounds (table 15).

The intraluminar stapler (ILS) was used in 51 of the 62 low and in 4 of the 26 high anterior resections. A diverting colostomy was performed in 15 of the low and in 4 of the high anterior resections. A tube caecotomy had been used in 33 of the low and in 6 of the high anterior resections; 14 low and 16 high anterior anastomosis were neither "protected" by a colostony nor a caecotomy.

Table 15: Bacteriological isolates from abdominal and perineal wound infections in patients operated on from 1984-87.

bacteria

abd. $(n=6) \quad$ perineal $(n=8)$

E. coli

B. fragivis

Pr: mirabilis

Streptococicus sp.

Sraph. anews

Staph epidermidis

Psendowamas sp.
2

1

4

2

3

4

Table 16."Bacteriological isolates from the abdominal and perineal wound infections of the rrial.

Organisms isolated

Op 1

$(n=6)$
$\mathrm{Gp} 2$

$(1+11)$
Gp 3

$(n=4)$

\section{Escherichia roti}

Bacteroides fragilis

Proters mirabilis

Streprococous sp.

Staphylococus aureas

$\begin{array}{ll}9 & 7 \\ 9 & 3 \\ 4 & 3 \\ 5 & 3 \\ - & 4\end{array}$

1
2
1
3




\section{Discussion}

Whole gut irrigation is now widely used as a preoperative bowel preparation. Compared with the traditional mechanical enema preparation, whole gut irrigation is rapid, well tolerated and yields the best degree of emptiness of the colon in comparison with any available method up to now, thus preventing intraoperative spillage of faeces and infection of the anastomosis. Whole gut irrigation by itself does not give any protection against postoperative septic complications. Wound infection rates of $30 \% 19]$ to $50 \%|35|$ have been reported when whole gut irrigation has been used without antibiotics. After whole gut irrigation, fluid retention occurs. For that reason it is contraindicated in patients with severe cardiac decompensation, although overloading of the circulatory system cannot really be demonstrated.

With mannitol-containing irrigation fluid, the absorption of fluid is less $[36]$ and the lavage procedure is shorter and better tolerated. Colonic explosions due to the formation of methane gas by anaerobic bacteria have been reported as a rare complication after the use of mannitol [37-39]. However, this fatal complication can be avoided by the use of oral antibiotics. Overgrowth of aerobic bacteria after preoperative bowel preparation is increasingly being reported [40-41]. For this reason the use of mannitol should not be recommended.

Whole gut irrigation with polyethylene glycol (Golytely) until a clear effluent is achieved, is a good alternative to mannitol or the balanced electrolyte solution. Its benefit is the lesser fluid absorption. Drinking of only 4 litres of polyethylene glycol however [44-53] has been reported to be inferior to the WGI procedure in obtaining a clean bowel [54].

In this study all patients received whole gut irrigation without mannitol. Although $90 \%$ of the patients were older than 50 years and several were more than 90 years old, the procedure was well tolerated and only in $5 \%$ (11 patients) did the whole gut irrigation have to be stopped because of vomiting and collapse. The cleansing of the colon in all three groups was comparable and was evaluated as excellent or good in more than $90 \%$ of the patients.

The dose of antibiotics was chosen arbitrarily and no special attention was paid to the level achieved in the serum or in the colon. The group receiving tetracycline was included in order to test the former standard policy. The two other antimicrobial groups contained agents which were effective against both aerobic and anaerobic flora. All the antimicrobial agents (except tobramycin) were prepared in the hospital pharmacy. Oxyletracycline appeared to be ineffective as a prophylaxis in this study, although it has been claimed in the past to be effective against aerobic and anaerobic bacteria. In the present study, its use failed to bring about adequate prevention of wound infection, septicaemia or anastomotic leakage.

Three patients died because of disruption of the anastomosis. A major part of the colonic flora appeared to be resistant to oxytetracycline. The rate of wound infections in the first two patient groups was high. In the second group $18.6 \%(13 / 70)$ of the patients developed abdominal wound infections, a figure higher than that reported after the use of metronidazole alone but comparable to the rates reponted by workers employing a similar definition of wound infection [55-57]. Septic complications in this group were mostly caused by aerobic bacteria. The use of tobramycin in group 2 did not show any benefit as prophylaxis against the aerobic bacteria. 
Two instances were found of septicaemia with aerobic micro-organisms and with disrupted anastomoses resulting in the death of both patients. The incapacity of tobramycin to control aerobic intections has also been reported by others 58.591 . In the third group, Bacteroides fragilis was eradicated, no septic complications occurred and there were no deaths due to septic complications. This is comparable to the results of other workers $[35,60-63]$ using oral neomycin and metronidazole. The differences in septic complications between the second and thitd groups were noted and were surprising. In both groups metronidazole was used orally, although in a different way, and only the use of tobramycin or neomycin was different. The fitst explanation of this difference could be the profound effect of neomycin and metronidazole in reducing the aerobic and anderobic flora $[19,64]$.

Comparison of the colonic cultures at operation with the microoganisms cultured from the wound infections [fig. I and table 16 ] shows a clear association between the species of bacteria isolated from the colon at operation and the species subsequently isolated from the postoperative wound infections and septicaemia. The lower the bacterial counts in the colon. the lower the septic complicarions proved to be. This might provide good evidence that these infections are caused by bacteria spilled into the wound from the bowel during the operation.

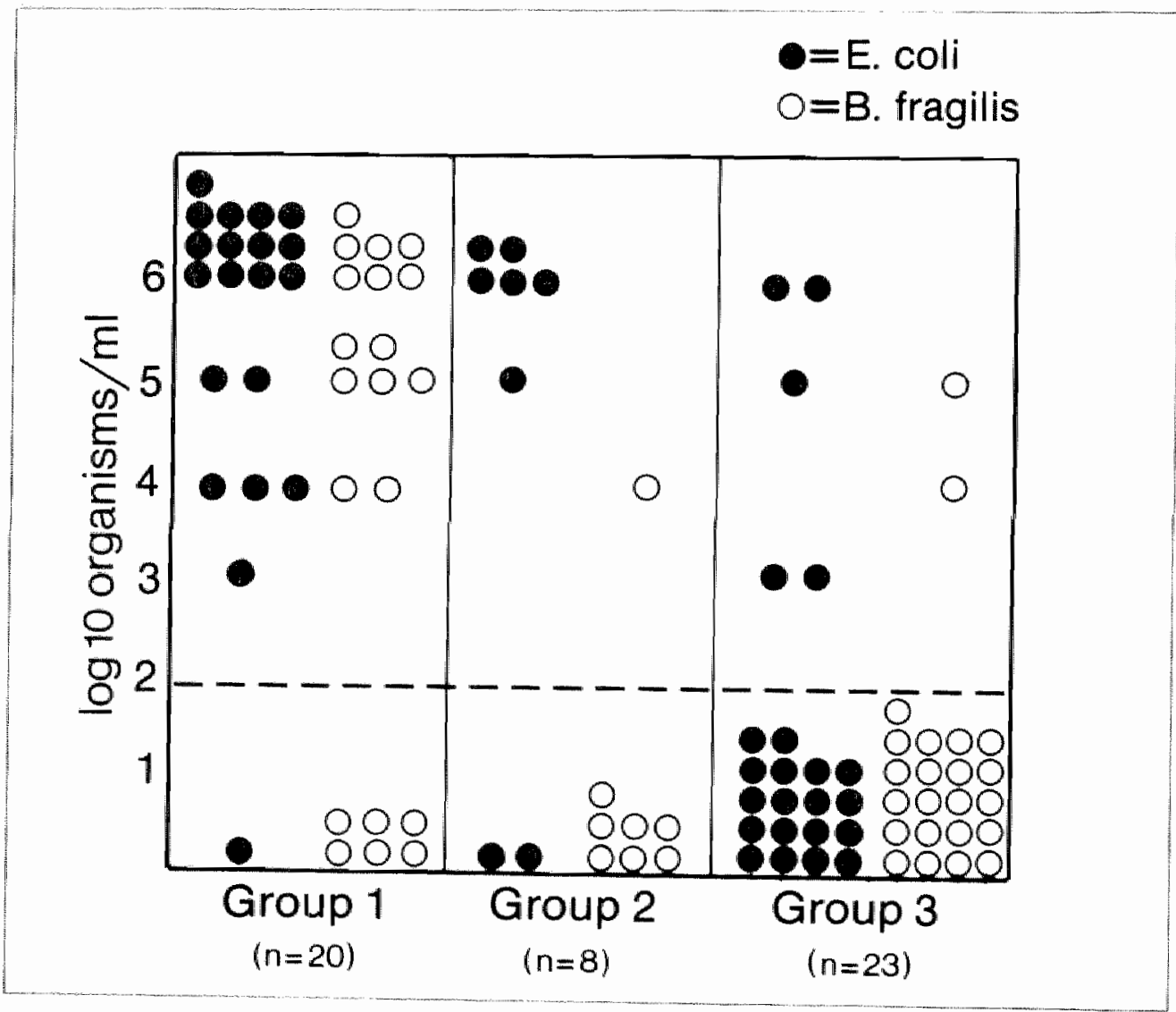

Fig. 1: E. coli and B. fragilis in the colon at operation. Cultures showing no growth are below the sensitivity of the bacteriological methods and are indicated ander the hatched $\operatorname{lin}(<\log 2)$. 
It was never the policy to attempt to sterilise the colon, atthough sterile colonic cultures were found during operation in $25 \%(2 / 8)$ of patients in group 2 and in $45 \%(10 / 23)$ of those in group 3. Intramucosal bacterial culture or counting was not performed.

The influence of neomycin and metronidazole on the colonic microflora of voluntears receiving a normal diet has been investigated by Arabi et al. $|65|$ who found that metronidazole alone had no influence on anaerobic faecal bacterit. Neomycin, on the other hand, was only effective against sensitive aerobes. However, the combination of neomycin and metronidazole profoundly reduced both the aerobic and the anterobic bacteria $|65|$.

Another study $[35]$ comparing oral neomycin and metronidazole in a group of patients with conventional bowel preparation to those in a group receiving these antimicrobial agents in the irrigation fluid (as in our group 3), showed that the capacity for reducing the aerobic and the anaerobic flora was significantly higher in the irrigated group.

The superior results in group 3 compared with group 2 could not be explained by the probably higher serum levels of metronidazole due to the fact that more of this drug was given in the third group. It is debatable, however, whether higher serum levels are desirable and as shown in this study only little difference in anaerobic septic complications between groups 2 and 3 was found.

The results of this trial show that neomycin and metronidazole in the whole gut irrigation fluid are highly effective in preventing post-operative septic complications in elective colorectal surgery. From a practical point of view it appears to be very easy to administer neomycin and metronidazole, and there is no need to worry about the correct timing of the administration in order to achieve a high serum level at the time of operation. The cost of this method of prophylaxis was not more than $\$ 6$ per patient.

In particular the reduced length of hospital stay in patients with complications in group 3 compared with that in the two other groups reflected once more the adequacy of this prophylaxis.

Resistance development with this oral regimen has not been noticed, either in the trial or in the group studied prospectively in 1984-87. Neomycin is only used for whole gut irrigation. Metronidazole and neomycin were administered in a high dose for only a few hours, and were not used afterwards in the same patient. No systemic toxicity with metronidazole (which is maximally absorbed) was noted, and there was no local toxicily of neomycin, which is handly absorbed at all.

Pseudomembranous colitis, a serious complication atter oral or parenteral use of antimicrobials, was not recorded. Reports on this complication seem to differ according 10 the patient populations studied, and percentages from 0 - $10 \%$ have been mentioned $\| 1$, 91.

Overgrowth of centain microorganisms after the oral use of antibiotics such as those in group 3 has been described but could not be detected in the present study, probably because of the very short duration and high dosage of the prophylaxis 1401.

Staphylococas ameus was cultured in the wo groups with oral antimicrobials but wats never cultured in the colon during operation.

All left-sided anastomoses in this study were investigated with gastrographic enematta. One might argue about the use of this method, but we had two reasons for performing it.

Firstly, comparison with the results by other surgeons [33] using the same method wass possible. The second, and more important, reason was that a colostomy after a left-sided anastomosis was not required as a standard procedure. If an anterior anastomosis wals made and found to be reliable (i.e. Waterproof) or intact proximal and distal rings of the Stapler 
apparatus were present, generally a colostomy was not performed except in extremely low resections. A catheter caecotony was often carried out in such patients. Later in this study (Group 1984-1987), this caccotomy was omitted in 14 patients, relying on uneventful healing of the anastomosis in the presence of a totally empty bowel, due to adequate antibiotic prophylaxis and the use of normal surgical techniques.

Postoperatively, all patients received a liquid diet or Nutrison ${ }^{R}$, until the performance of the $X-1 a y$.

In the absence of leakage. normal oral feeding was initiated and the caecotomy catheter removed. If a leakage was present, the residue-free diet was continued for another 10 days. With this policy. morbidity due to the presence and subsequent closure of a colostomy could be prevented in many pationts.

\section{Conclusions}

- As a preoperative bowel preparation, whole gut irrigation is well tolerated, rapid, safe and economical and it has an optimal bowel cleansing capacity. It can be recommended as the best method currently available for pre-operative preparation in elective colorectal surgery.

- Very short term prophylaxis with neomycin and metronidazole in the irrigation fluid alone appears from this study to be by far the cheapest and does not give rise to systemic or local toxicity.

- Both good reduction in the concentration of the colonic microflora and adequate serum levels of metronidazole during operation were achieved. As a consequence it is highly effective in preventing wound infection and septicaemia. Most important of all, a dramatic reduction in anastomotic leakages is seen. 


\section{References}

1. Cahn I Jr.

Intestinal antisepsis.

Surg Gynecol Obstet 1970;130:1006-14.

\section{Ravitch MM.}

Some considerations on the healing of intestimal anastomoses.

Surg Clin North Am 1969:49:627-35.

3. Rusca JA, Bornside GH., Cohn IJr.

Everting versus inverting gastrointestinal anastomoses: bacterial leakage and anastomolic disruption.

Ann Surg 1969;169:727-35.

\section{Bornside GH, Cohn I Jr.}

Intestinal antisepsis; stability of fecal flora during mechanical cleansing.

Gastroenterology 1969;57:569-73.

\section{Gaylor DW, Clarke JS, Kudinoff Z, Finegold SM.}

Preoperative bowel "sterilization" -a double-blind study comparing kanamycin, neomycin and placebo.

Antimicrob Agents Ann 1960;392-4.

6. Nichols RL, Broido P, Condon RE, Gorbach SL, Nyhus LM.

Effect of preoperative neomycin-erythromycin intestinal preparation on the incidence of infectious complications following colon surgery.

Ann Surg 1973; 178:453-62.

\section{Nichols RL, Gorbach SL, Condon RE.}

Alteration of intestinal microflora following preoperative mechanical preparation of the colon.

Dis Colon Rectum 1971:14:123-27.

8. Figueras-Felip J, Basilio-Bonet E, Lara-Eisman F, et al.

Oral is superior to systemic antibiotic prophylax is in operations upon the colon and rectum. Surg Gynecol Obstet 1984:158:359-62.

\section{Gottrup F, Diederich $\mathrm{P}$, Sorensen $\mathrm{K}$, Nielsen $\mathrm{SV}$, Ornsholt J, Brandsborg $\mathrm{O}$.}

Prophylaxis with whole gut irrigation and antimicrobials in colorectal surgery. A prospective, randomized double-blind clinical trial.

Am J Surg 1985;149:317 22 .

10. Raahave D, Hansen OH, Carstensen HE, Friis-Moller $\mathbf{A}$.

Septic wound complications after whole bowel irrigation before colorectall operations.

Acta Chir Scand 1981:147:215-8.

\section{Debo Adeyemi S, Tai da Rocha-Afodu J.}

Clinical studies of 4 methods of bowel preparation in colorectal surgery.

Eur Surg Res 1986; 18:331-6. 
12. Baum ML, Anish DS, Chalmers TC, Sacks HS, Smith H, Fagerstrom RM.

A survey of climical trials of antibiotic prophylaxis in colon surgery: Evidence against further use of no-treatment controls.

N Engl I Med 1981:305:795-9.

13. Willis AT, Ferguson IR, Jones PH, et al.

Metronidazole in prevention and treatment of bacteroides infections in elective colonic surgery.

Brit Med J 1977; 1:607-10.

\section{Brass C, Richards GK, Ruedy J, Prentis J, Hinchey EJ.}

The effect of metronidazole on the incidence of postoperative wound infection in elective colon surgery.

Am J Surg 1978;135:91-6.

\section{Bjerkeset T, Digranes A.}

Systemic prophylaxis with metronidazole (Flagyl) in elective surgery of the colon and recturn.

Surgery 1980;87:560-6.

\section{Hinchey EJ, Richards (GK, Lewis R, Echave V, Biron JS, Weissglass I.}

Moxalactam as single-agent prophylaxis in the prevention of wound infection following colon surgery.

Surgery 1987:101:15-9.

\section{Barone C, Hell K.}

Neomycin versus Neomycin plus Metronidazol zur Dickdarmvorbereitung in der elektiven Kolonchirurgie.

Helv Chir Acta 1980;47:511-6.

\section{Roland M, Bergan 'T, Aase $S$, et all.}

Prophylactic regimens in colorectal surgery: an open, randomized, consecutive trial on metronidazole used allone or in combination with ampicillin or doxycycline.

Wortd J Surg 1986:10:1003-8.

\section{Vallance S, Jones B, Arabi Y, Keighley MRB.}

Importance of adding neomycin to metronidazole for bowel preparation.

$J \mathbb{R}$ Soc Med 1980;73:238-40.

\section{Washinton JA II, Dearing WH, Judd ES, Elveback LR.}

Elfect of preoperative antibiotic regimen on development of infection after intestinal surgery: prospective, randomized, double-blind sudy.

Ann Surg 1974:180:567-72.

\section{Juul P, Klaaborg KE, Kronborg $O$.}

Single or multiple doses of metronidazole and ampicillin in elective colorectal surgery. A randomized trial.

Dis Colon Rectum 1987;30:526-8. 
22. Kusche J, Stahlknecht CD.

Antibioticaprophylaxe bei colorectalen Operationen: Gibt es ein Mittel der Wahl?

Chirurg 1981;52:577-85.

\section{Lindhagen J, Andaker L, Hojer $\mathbf{H}$.}

Comparison of systemic prophylaxis with metroniclazole/placebo and metronidazole/ fosfomycin in colorectal surgery. A clinical study demonstrating the need for additional anti-aerobic prophylactic cover.

Acta Chir Scand 1984;150:317-23.

\section{Clarke JS, Condon RE, Bartlett „IG, Gorbach SL, Nichols RL, Ochi S.}

Preoperative oral antibiotics reduce septic complications of colon operations: results of prospective, randomized, double-blind clinical study.

Ann Surg 1977; 186:25 1-9.

\section{Keighley MRB, Arabi X, Alexander-Williams J, Youngs D, Burdon DW.}

Comparison between systemic and oral antimicrobial prophylaxis in colorectal surgery.

Lancet $1979 ; 1: 894-7$.

26. Condon RE, Bartlett JG, Nichols RL, Schulte WJ, Gorbach SL, Ochi S.

Preoperative prophylactic cephalothin fails to control septic complications of colorectal operations: results of controlled clinical trial.

Am J Surg 1979;137:68-74.

\section{Edmondson HT, Rissing JP.}

Prophylactic antibiotics in colon surgery: cephaloridine versus erythromycin and neomycin. Arch Surg 1983;118:227-31.

\section{Condon RE, Bartlett JG, Greenlee H, et al.}

Efficacy of oral and systemic antibiotic proplyylaxis in colorectal operations.

Arch Surg 1983:118:496-502.

\section{Weaver M, Burdon DW, Youngs DJ, Keighley MRB.}

Oral neonycin and erythromycin compared with single-dose systemic metronidazole and ceftriaxone prophylaxis in elective colorectal surgery.

Am d Surg 1986; 151:437-42.

\section{Dudley HAF, Radcliffe AG, McGeehan D.}

Intraoperative irrigation of the colon to permit primary anastomosis.

Brit J Surg 1980;67:80-1.

\section{Hewitt J, Reeve „I, Rigby J, Cox AG.}

Whole gut irrigation in preparation for large bowel surgery.

Lancet 1973:2:337-40.

\section{Crapp AR, Tillotson P, Powis SJA, Cooke WT, Alexander-Williams J.}

Preparation of the bowel by whole-gut irrigation.

Lancet $1975 ; 2: 1239-40$. 


\section{Goligher JC, Graham NG, De Dombal FT.}

Aftastomonc dehiscence after anterior resection of rectum and sigmoid.

Brit J Surg 1970;2:109-18.

\section{Irvin TT, Golligher JC.}

A controlled clinical trial of three different methods of perineal wound management following excision of the rectum.

Br J Surg 1975;62:287-91.

\section{Weidema WF.}

Whole gut irrigation and antimicrobial prophylaxis in elective colorectal surgery [Thesis]. Maastricht: State University of Limburg,1982. pp 107.

\section{Hares MM, Alexander-Williams J.}

The effect of bowel preparation on colonic surgery.

World J Surg 1982;6:175-81.

\section{Zanoni CE, Bergamini C, Bertoncini M, Bertoncini L, Garbini A.}

Whole-gut lavage for surgery. A case of intraoperative colonic explosion after administration of mannitol.

Dis Colon Rectum 1982;25:580-1.

\section{Keighley MRB, Taylor EW, Hares MM, et all.}

Influence of oral mannitol bowel preparation on colonic microflora and the risk of explosion during endoscopic diathermy.

Br JSurg $\llbracket 981 ; 68: 554-8$.

\section{Bigard MA, Gaucher P, Lassalle $C$.}

Fatal colonic explosion during colonoscopic pollypectomy.

Gastroenterology 1979;77:1307-10.

40. Keighley MRB, Lee JR, Ambrose NS.

Indications and techniques for bowel preparation in colorectal cancer.

Int Adv Surg Oncol 1983:6:257-70.

41. Coevorden $\mathrm{F}$ van, Taat $\mathrm{CW}$, Boissevain $\mathrm{AC}$, et al.

Pre-operative whole-gut inrigation with mannitol.

Neth I Surg 1982:34:225-8.

\section{Michael KA, DiPiro JT, Bowden TA, Tedesco F.J.}

Whole-bowel irrigation for mechanical colon cleansing.

Clin Pharm 1985:4:414-24.

\section{Caos A, Benner KG, Manier J, et al.}

Colonoscopy after Golytely preparation in acute rectal bleeding.

I Clin Gastroenterol 1986:8:46-9. 
44. Ernstoff JJ, Howard DA, Marshall JB, Jumshyd A, McCullough AJ.

A randomized blinded clinical trial of a rapid colonic lavage solution (Golytely) compared with standard preparation for colonoscopy and barium enema.

Gastroenterology 1983;84:1512-6.

45. DiPalma JA, Brady CE III, Stewart DL, et al.

Comparison of colon cleansing methods in preparation for colonoscopy.

Gastroenterology 1984;86:856-60.

46. Fleites RA, Marshall JB, Eckhauser ML, Mansour EG, Imbembo AL, McCullough AJ.

The efficacy of polyethylene glycol-electrolyte lavage solution versus traditional mechanical bowel preparation for elective colonic surgery: a randomized, prospective, blinded clinical trial.

Surgery 1985:98:708-17.

47. Beck DE, Harford FJ, DiPalma JA.

Comparison of cleansing methods in preparation for colonic surgery.

Dis Colon Rectum 1985;28:491-5.

48. Beck DE, Fazio VW, Jagelman DG.

Comparison of oral lavage methods for preoperative colonic cleansing.

Dis Colon Rectum 1986;29:699-703.

\section{Thomas G, Brozinsky S, Isenberg JI.}

Patient acceptance and effectiveness of a balanced lavage solution (Golytely) versus the standard preparation for colonoscopy.

Gastroenterology 1982;82:435-7.

50. Minervini S, Alexander-Williams J, Donovan IA, Bentley S, Keighley MRB.

Comparison of three methods of whole bowel irrigation.

Am J Surg 1980; 140:400-2.

51. Ambrose NS, Johnson M, Burdon DW, Keighley MRB.

A physiological appraisal of polyethylene glycol and a balanced electrolyte solution a bowel preparation.

Br J Surg 1983;70:428-30.

\section{Bowden TA Jr, DiPiro JT, Michael KA.}

Polyethylene glycol electrolyte lavage solution (PEG-ELS). A rapid, safe mechanical bowel preparation for colorectal surgery.

Am Surg 1987:53:34-6.

\section{Beck DE, Harford F.J, DiPalma JA, Brady CE IIII.}

Bowel cleansing with polyethylene glycol electrolyte lavage solution.

South Med J 1985;78:1414-6.

54. Van der Heide H, Lantink JA, Wiltink E, Tytgat GN.

Comparison of whole-gut irrigation with Golytely (GOL) and with a balanced electrolyte solution (BES) as preparation for colonoscopy.

Endoscopy 1986;18:182-4. 
55. Begge WD, Jobanputra RS, Holmeg IT.

A compatison of irtravenous and oral meironidazole as prophylactic in colorectal surgery. Br J Surg 1982;69:226-7.

56. Ractzel G, Harnoss BM, Goertz G, Haering R, Rodloff A.

Systenische Antibiotikaprophylaxe mit Metronidazol in der elektiven Kolon- und Rektumchirurgie. Ergebnisse einer klinisch-kontrolherten Studie und kritische Literaturubersicht. Arzneinittellorschung 1986;36:976-80.

57. Rolland M, Bergan T, Bjerkeset " $T$, et al.

Prophylactic regimens in colorectal surgery: comparisons between metronidazole used alone or with ampicillin for one or three days.

World J Surg 1985:9:626-32.

\section{Burdon DW, Keighley MRB, Alexander-Williams J.}

Prophylactic trials in colon strgery with special regard to bowel preparation.

Aktuel Probl Chir Orthop 1981;19:97-100.

\section{Keighley MRB, Crapp AR.}

Short term prophylaxis with tobramycin and lincomycin.

Scotll Med I 1976;21:70-3.

60. Matheson DM, Arabi Y, Baxter-Smith D, Alexander-Williams J, Keighley MRB.

Randomized multicentre trial of oral bowel preparation and antimicrobials for elective colorectal operations.

Br J Surg 1978;65:597-600.

61. Keighley, MRB, Arabi Y, Matheson D, Alexander-Williams J.

Aspects of preventing sepsis in colo-rectal surgery; results of recent clinicall trials.

I Antimicrob Chenother 1978;4(suppl C):33-38.

62. Playforth MJ, Smith GMR, Evans M, Pollock AV.

Ancimicrobial bowel preparation. Oral, parenteral or both?

Dis Colon Rectum 1988:31:90-3.

63. Wolf BG, Beart RW Jr; Dozois RR, et al.

A new bowel preparation for elective colon and rectal surgery. A prospective, randomized clinical trial.

Arch Surg 1988:123:895-900.

64. Nichols RL, Condon RE, Gorbach SL, Nyhus L.M.

Efficacy of preoperative antimicrobial preparation of the bowel.

Ann Surg 1972:176:227-32.

65. Arabi $Y$, Dimock F, Burdon DW, Alexander-Williams J, Keïghley MRB.

Influence of neomycin and metronidazole on colonic microflora of volunteers.

J Antimicrob Chemother. 1979:5:531-7. 


\section{Chapter 5}

\section{Intraoperative colon irrigation to permit left sided primary resection and anastomosis in the unprepared colon}

\section{Introduction}

Faecal loading proximal to a colonic anastomosis increases technical difficulties and is a primary cause of anastomotic dehiscence [1]. In addition, contamination of the peritoneum and wound leads to increased sepsis. Preoperative irrigation of the colon has made it possible for the loaded but unobstructed colon to be mechanically prepared to a high standard [2].

However, the method is not applicable in about $20 \%$ of the patients in whom an grow may have considerably constricted the lumen of the bowel, and it is also inadequate in up to $20 \%$ of the patients without an obstruction, in whom optimat bowel preparation is not possible for several reasons.

Usually when faecal loading is found at operation because of obstruction of the left colon, either only a defunctioning colostomy is performed or the lesion is resected without an anastomosis.

Multiple operations may lead to increased complications and about $30 \%$ of the patients may never receive definitive treatment $[3,4]$. Especially, elderly parients with obstructing carcinoma and advanced local disease or metastases in the liver are particularly debilitated by the prolonged hospital stay and the accompanying stomal problems.

Intrapperative colon irrigation (a method for cleansing the colon at operation) as modified by Dudley in 1980 has been used in order to perform a primary resection and anastomosis in the left colon in patients who are unprepared (emergency surgery) or ill prepared (elective surgery). This method enables us to establish an "elective envitonment" at "non elective times".

In this chapter the experience and results of this method are reported.

\section{Methods}

\section{Defïnitions}

Large bowel obsmuction: symptoms of constipation, pain and vomiting; the signs of abdominal distention and abnomal faecal distention of the gut or stenosis as shown by (contrast) radiography; at laparotomy findings of proximal bowel distention and oedema. Patients with simple loading of the proximal colon with faeces not removed by bowel preparation were not included. 
Primary resection: removal of the cancer at the furst operation, not necessarily with a synchronous anastomosis. Staged resection: removal of the cancer at a later operation other than the first (during which decompression, usually by a loop colostomy, had been performed).

Right colon: the colon proximal to the splenic flexure. The transwerse colon is included with the right colon for practical purposes, because obstructing carcinoma in this region can be treated by an extended right hemicolectomy.

Lefi colon: the collon at or distal to the splenic flexure.

\section{Surgical strategy}

Definitive surgery for obstructing cancers of large bowel demands the presence of a qualified surgical team. Operations carried out in the middle of the night on mostly old and fragile patients, and with an inexperienced team, should be avoided if possible.

Two thinds of large bowel obstructions are closed-loop in nature because of a competent ileocaecal value. However, these patients do not often constitute true emergencies in the sense that the patient need not to be rushed to the operating room within an hour or so of presentation. It is wise to take a more deliberate approach except in cases where peritonitis is present or there is a chance of perforation due to severe collonic distention.

\section{Preoperative management}

A nasogastric tube is inserted in all patients admitted with large bowel distention. At least a peripheral infusion is given on admission but a central. infusion system, through which parentenal feeding and rehydration can take place, is introduced as soon as necessary. Care should be taken not to overfill the circulation. Assessment of the cardiovascular and metabolic state is necessary in order to judge the feasibility of the intraoperative irrigation procedure.

Confirmation of the diagnosis of organic obstruction, either by a gastrographin enema or by endoscopy, should always be done.

\section{Operative technique}

The first dose of broad spectrum antibiotic (tobramycin-metronidazole) is given intravenously at the induction of anaesthesia. If a process proximal to the splenic flexure is expected the patient is placed on his back with legs extended. If the lesion has been located distal to the sigmoid or in the rectum, the patient should be placed in an extended lithotomy position. The main advantage of this position is that access to the anus both for the washout and for introducing a stapling device or rectal tube is facilitated [5].

The operator stands to the left side of the patient. A midline incision from the xiphoid is carried down to the suprapubic area, skirting to the left side of the umbilicus. At the lower end the anterior rectus sheet is split right down to the peritoneum if adequate exposure is necessary. After the peritoneum has been opened, distended bowel will protrude in case of longstanding ileus. Before further exploration is undertaken, the colon is decompressed and gas is allowed to escape. For this purpose a 21 gauge needle is attached to a sucker and 

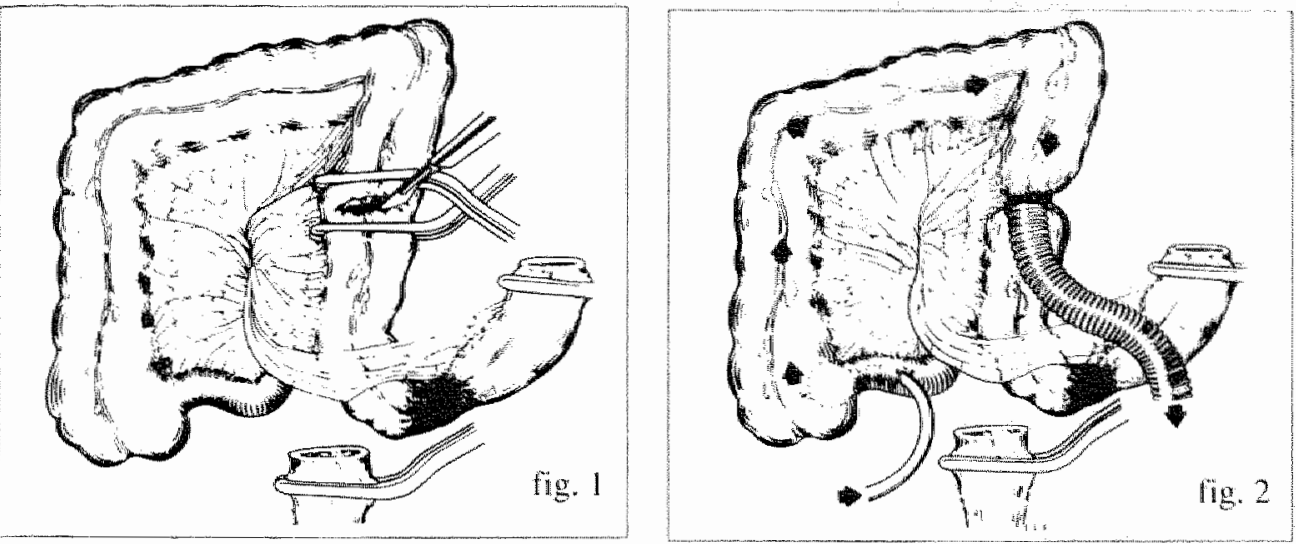

Fig. 1. Colotomy for insertion of irrigation thbe (from Radcliffe et al. $151 \mathrm{~J})$.

Fig. 2." Tube ileostomy and inrigation tube in situ (from Radcliffe el al. 1517 ).

inserted through a taenia in the transverse colon while pressure is applied to both flanks so as to force gas out of the ascending and descending colon. The needle point is kept in the gas bubble or it will soon become choked with faeces. If collonic distention is moderate, suction as alternative can be done after introduction of the Foley catheter necessary for the intraoperative irrigation.

Should the small bowel be distended, it is emptied by retrograde stripping into the stomach [6] and the contents withdrawn by a wide bore nasogastric tube.

Inspection of the abdominal organs is carried out with special attention to detection of liver metastases or other signs of incurability. The presence of these is an additional reason for a one-stage procedure. The lesion (usually an obstructing tumour) is mobilised at the choice of the surgeon. It is essential that the splenic flexure should be mobilised for if this is not done attempts to manipulate faeces past it may tear adhesions and cause splenic bleeding. The intestime is divided distally with the colon drawn laterally, and a slightly greater length of intestine than usual is cleared proximally and isolated between clamps.

A side opening is made in the bowel above the obstruction [fig. I] and cannulated with a cortugated tube (anaesthetic gas scavenging tubing) which is secured with two strong encircling cotton tapes. Alternatively, the lesion car be resected and removed, minimising the chance of tumour cell spillage, and the irrigation drainage tube securely ried to the proximal cut end of the large bowel [fig. 2].

A long plastic bag is fixed to the distal end of the tube and is led to a bucket beside the operating table. The caecun is then mobilised. In the presence of the appendix a 14 foley catheter is placed in the caecum through the amputated appendix stump. In the absence of the appendix a purse-string is made into the ileum $5 \mathrm{~cm}$ proximal to the ileocoecal valve and the Foley catheter introduced through a small ileotomy.

For colonic irrigation two three-litre bags containing Hartmann solution without antibiolics, (at $370 \mathrm{C}$ ) are connected to the Foley catheter. Before irrigation, a non-crushing clamp is placed on the terminal ileum to prevent reflux into the small bowel during lavage. As the colon fills with the irrigant, gentlle colonic manipulation, breaking rigid contents with the 


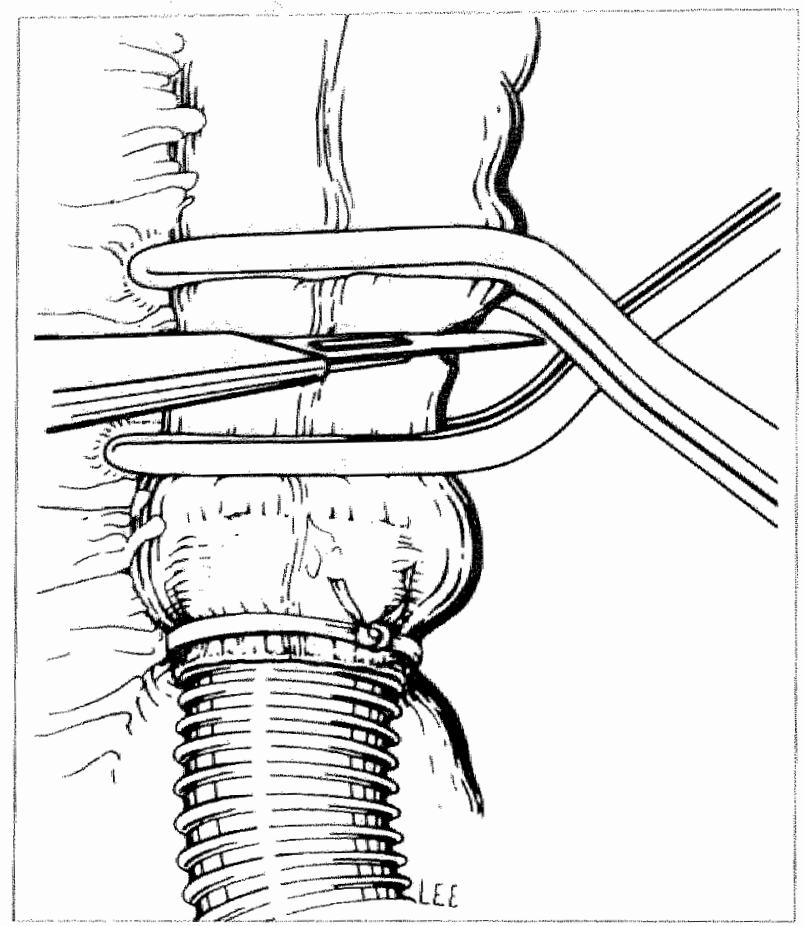

Fig. 3: Resection proximal to the irrigation drainage tube (from Radcliffe et al. 1517).

fingers, facilitates the transport of the colonic contents into the distal drainage system. Irrigation is carried out until the effluent is totally clear. At the end of this procedure mesenteric resection is completed if it has not been done already. The colon is divided between the two clamps placed proximal to the drainage tube, at a convenient site for the anastomosis [fig. 3].

The Fotey catheter can be removed but in most of the patients it is used as a tube caecotomy. Particular care is taken to make the caecostomy safe. The tube is secured in the caecum by a double purse-string seromuscular suture using Vicryl ${ }^{R} 3 \times 0$. If Vicryl $2 \times 0$ is employed for this purpose then its removal after 10 days might appear to be difficult due to the strength of the thicker thread. The caecum is attached to the parietal peritoneum at at least four points by interupted VicrylR $3 \times 0$, picking up the seromuscular edge of the caecostomy.

The distal resection site is cleansed with $1 \%$ povidone iodine and the anastomosis made using either one-layer chromic catgut 2.0 or continuous seromuscular chromic catgut and inverting serosal VicrylR 3-0. The anastomosis is tested for leakage by installation of methylene blue or povidone-iodine $1 \%$ through the rectal tube and placing a soft clamp proximal to the anastomosis. All anastomoses are covered with omentum when possible. If an anterior resection is plamned during laparotomy, the omentum is lengthened in the beginming to judge its viability when the anastomosis is covered. Only if the anastomosis is located retroperitoneally (low anterior resections) are redon drains used as a routine. The operation finishes with introduction of a needle-jejunum catheter. The peritoneum with running $V_{\text {icryl }} \mathbb{R}_{1-0}$, the fascia with interrupted Vicryl ${ }^{R}$ I-0 and the skin with intertupted nylon $4 \times 0$. 


\section{Postoperative management}

The antibiotics, started preoperatively, are given twice more al intervals of 8 hours, unless the surgeon decides intraoperatively (due to spillage of faecal content or the presence of intra-abdominal septic sources) to continue them for a longer period.

Postoperative feeding with Peptison ${ }^{R}$ or Nutrison ${ }^{R}$ is commenced through the needlejejunum catheter 24 hours after operation and is continued until the radiological control of the anastomosis. This is done on the tenth day in all patients with a left sided anastomosis.

The tube caecostomy is kept patent by flushing with $30 \mathrm{ml}$ saline three times daily and is removed after the anastomotic integrity has been controlled radiographically and no leakage found to be present. Normal oral feeding is then started.

\section{Early modifications to the technique}

After intraoperative colon irrigation, some fluid remains in the colon. Leakage of this fluid rich in bacteria has to be prevented and therefore its removal is necessary. For this purpose the Foley catheter is connected to a $\mathrm{CO}_{2}$ meter which is normally available in the operating theatre and used by the gynaecologist for abdominal distention before introducing the laparoscope. The $\mathrm{CO}_{2}$ is blown (up to $30 \mathrm{~mm} \mathrm{Hg}$ ) through the colon and the majority of the fluid is removed by this gas stream.

A little fluid still remains in the descending colon but is removed by controlled suction through the Foley catheter. Due to the fact that faecal material has already been removed, the opening in the Foley catheter does not become choked. As a result an empty bowel (without the risk of peritoneal soiling) is achieved before the anastomosis is performed.

\section{Patients}

From July 1984 to December 1988 the intraoperative colon irrigation was employed in 41 patients for various reasons (table 1). In one patient, who had a diverting colostomy at the descending colon, a conservatively untreatable faecal impaction developed after contrast radiography had been performed. Three weeks later, and after many unsuccessful attempts to empty the colon, an intraoperative colon irrigation was performed and succeeded in relieving the faecal impaction [fig.4].

Not all patients admitted with obstruction were operated on in one stage after ICl. The presence of a surgeon familiar with the method and the suitability of the patients for the procedure were the limitations.

In the beginning, all operations were performed by one surgeon, but later on registrars also started employing this method under supervision. The operations performed are listed in table 2.

There were more females (25) than males (16), with an average age of 66 years. The three patients over the age of 80 were women (table 3). 
Table 1: Diagnoses of patients whergong inmaoperative colon inrigation.

1. Obstructing left sided tumour

2. Non obstructing left sided tumour

3. Previous Hartmann procedure

2

4. Diverticulitis

5. Fistulae:

recto-vaginal (diverticulitis) ileo-sigmoid (Crohn's disease) colon-right hip (divert; carc.)

6. Fiecal impaction

7. Obstructive megacolon

8. Obstruction after Ripstein operation

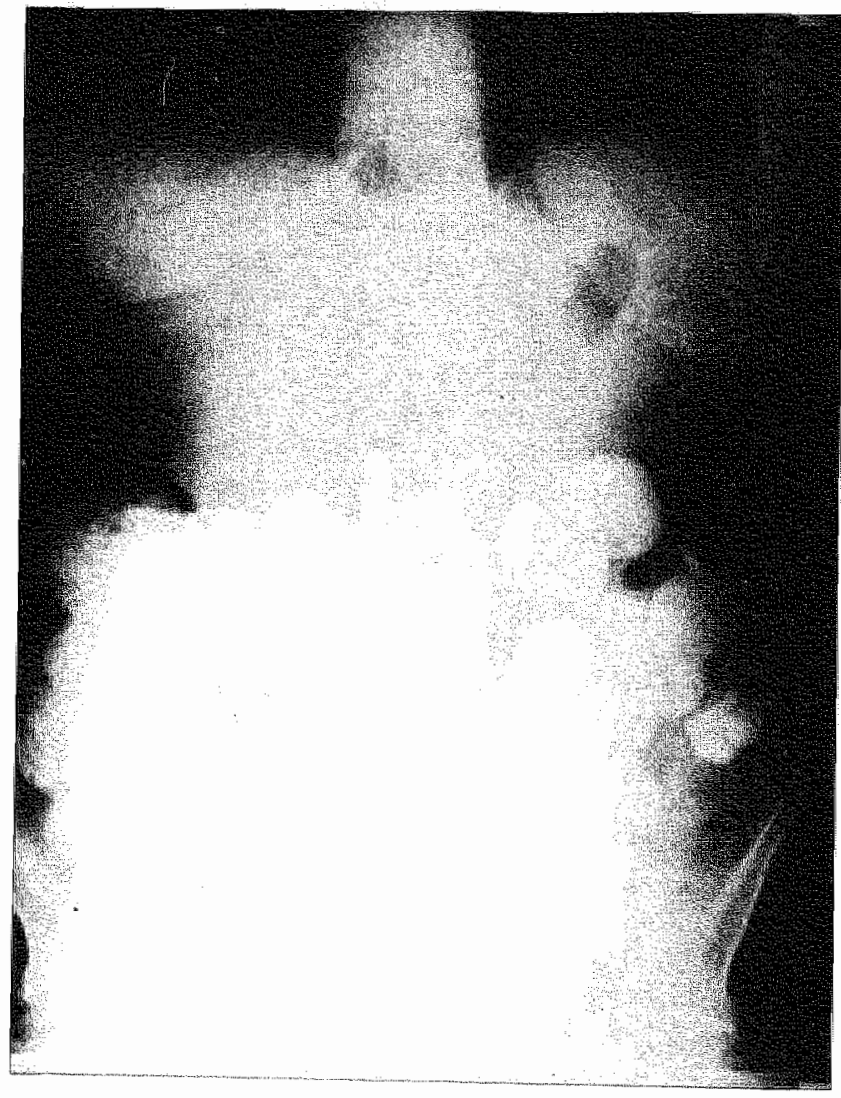

Fig. 4: Patient with conservarvely wheatable faccat impaction despite the presence of a diverting colostomy at the descending colon. 
Table 2: Operations performed

1. Anterior resection - high 11

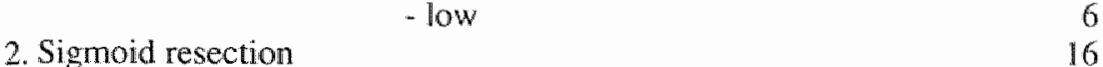

3. Left hemicolectomy 5

4. Reanastomoses Hartmamn 2

5. Intraoperative colon irrigation (alone)

Table 3: Age distribution of patients undergoing intraoperative colon imrigation.

\section{Age distribution of patients undergoing intraoperative colon irrigation.}

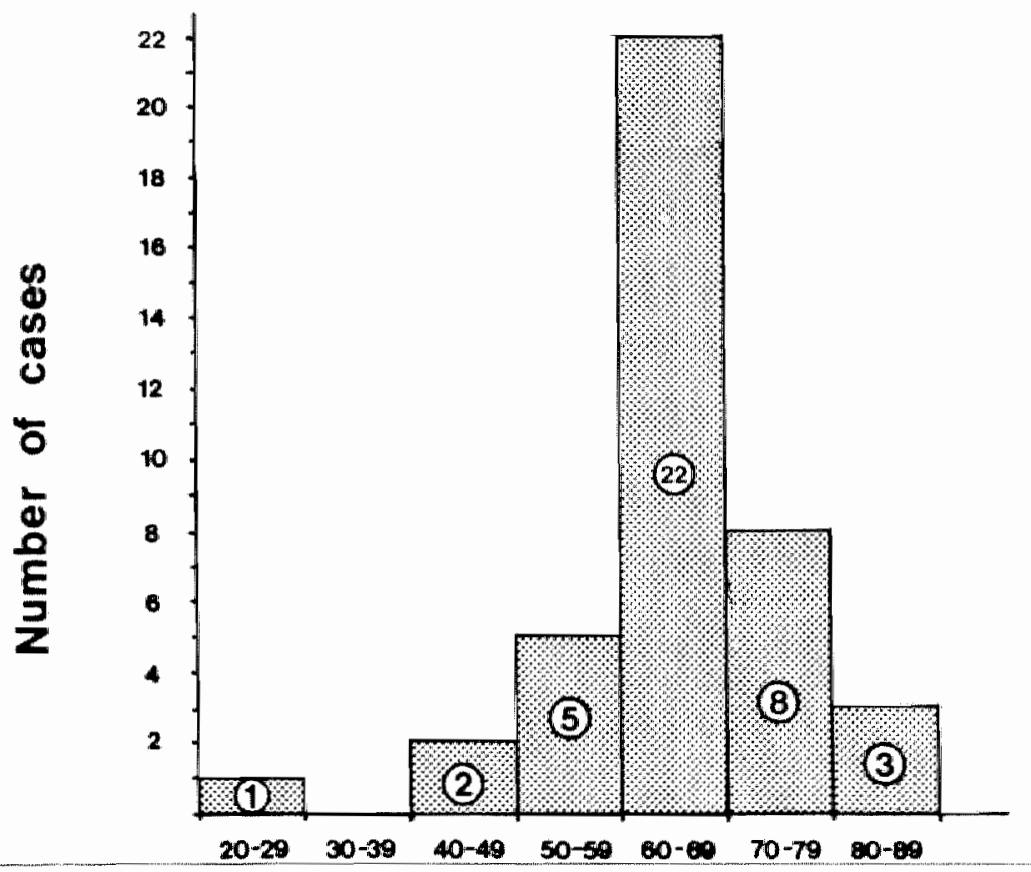


Table : Type of anastomosis related to the operation.

\begin{tabular}{|c|c|c|c|c|}
\hline \multirow[b]{2}{*}{ Operations performed } & \multirow[b]{2}{*}{$\begin{array}{l}\text { number of } \\
\text { patients }\end{array}$} & \multicolumn{2}{|c|}{ anastomoses } & \multirow[b]{2}{*}{$\begin{array}{r}\text { EEA } \\
\text { Stapler }\end{array}$} \\
\hline & & $\begin{array}{l}\text { one } \\
\text { layer }\end{array}$ & $\begin{array}{r}\text { two } \\
\text { layers }\end{array}$ & \\
\hline \multirow{2}{*}{$\begin{array}{r}\text { 1. Anterior resection - high } \\
-10 \mathrm{w}\end{array}$} & 11 & 5 & 5 & 1 \\
\hline & 6 & & & 6 \\
\hline 2. Signoid resection & 16 & 9 & 6 & 1 \\
\hline 3. Left hemicolectomy & 5 & 3 & 2 & \\
\hline 4. Reanastomoses Hartmann & 2 & 1 & 」. & \\
\hline 5. Intraoperative colon imigation (alone) & 1 & & & \\
\hline
\end{tabular}

\begin{tabular}{lllll} 
Total & 41 & 18 & 14 & 8 \\
\hline
\end{tabular}

Table 5: Stomara related to the type of operation.

$\begin{array}{rrrr} & \text { number of } & \text { coeco- } & \text { colo- } \\ \text { Operations performed } & \text { patients } & \text { stomy } & \text { stomy }\end{array}$

1. Anterior resection - high

- low

2. Sigmoid resection

3. Left hemicolectomy

4. Reanastomoses Hartmann

5. Intraperative colon irrigation (alone)
11

6

16

5

2

1

Potal

41

29

2 


\begin{tabular}{|c|c|c|c|c|c|c|c|}
\hline \multirow[b]{2}{*}{ Operations performed } & \multirow{2}{*}{$\begin{array}{l}\text { number of } \\
\text { patients }\end{array}$} & \multicolumn{2}{|c|}{$\begin{array}{l}\text { wound } \\
\text { infect. }\end{array}$} & \multicolumn{2}{|c|}{$\begin{array}{l}\text { anast. } \\
\text { leakage }\end{array}$} & \multicolumn{2}{|c|}{ death } \\
\hline & & min. & maj. & rad. & din. & $\mathrm{cp}$ & cal \\
\hline $\begin{array}{l}\text { 1. Anterior resection - high } \\
\text { 2. Sigmoid resection } \\
\text { 3. Left hemicolectomy } \\
\text { 4. Reanastomoses Hartmann } \\
\text { 5. Intraoperative colon } \\
\text { irrigation (alone) }\end{array}$ & $\begin{array}{r}11 \\
6 \\
16 \\
5 \\
2 \\
1\end{array}$ & $\begin{array}{l}2 \\
1\end{array}$ & 2 & 1 & 2 & $\begin{array}{l}1 \\
2\end{array}$ & 1 \\
\hline Total & 41 & 4 & $\begin{array}{r}2 \\
4.6 \%\end{array}$ & 1 & $\begin{array}{r}2 \\
7.3 \%\end{array}$ & 3 & $\begin{array}{r}1 \\
9.8 \%\end{array}$ \\
\hline $\begin{array}{l}\mathrm{cp}=\text { cardiopulmonary } \\
\mathrm{ca}=\text { carcinoma }\end{array}$ & & & & & & & \\
\hline
\end{tabular}

\section{Results}

Intraoperative colon irrigation lasted from 20-80 minutes (mean 40 minutes) in which 7.4 litres (4-12 litres) was needed to achieve a clear effluent.

The average hospital stay in patients without a clinical anastomotic leakage was 19 days.

A total of 40 left sided anastomoses were made (table 4) using enther a one- or a iwo layer technique. All low anterior anastomoses were created with a EEA-stapling device. As an exception, one anastomosis was made with the stapling device after sigmoid resection. The general policy (being a teaching hospital with budgetary limitations) is not to perform a mechanical anastomosis if it can easily be made by hand.

Only two diverting colostomies were necessary in patients undergoing high anterior resections. Two colostomies were performed (second operations) for faecal cliversion after clinical anastomotic leakages. In hardly any of the patients was a ube caecosiomy made in order to decompress the anastomoses (table 5 ).

Moderate (minor) wound infections were noted in 4 patients bul they healed without surgical intervention. Two severe (major) wound infections were noted.

In one of these patients, after a prolonged use of corticosteroids, a peristomal abcess developed and it had to be drained operatively. After the patient's discharge from the hospital and removal of the tube, a persisting fistula occurred which was treated operatively one year later after a laparotomy. 


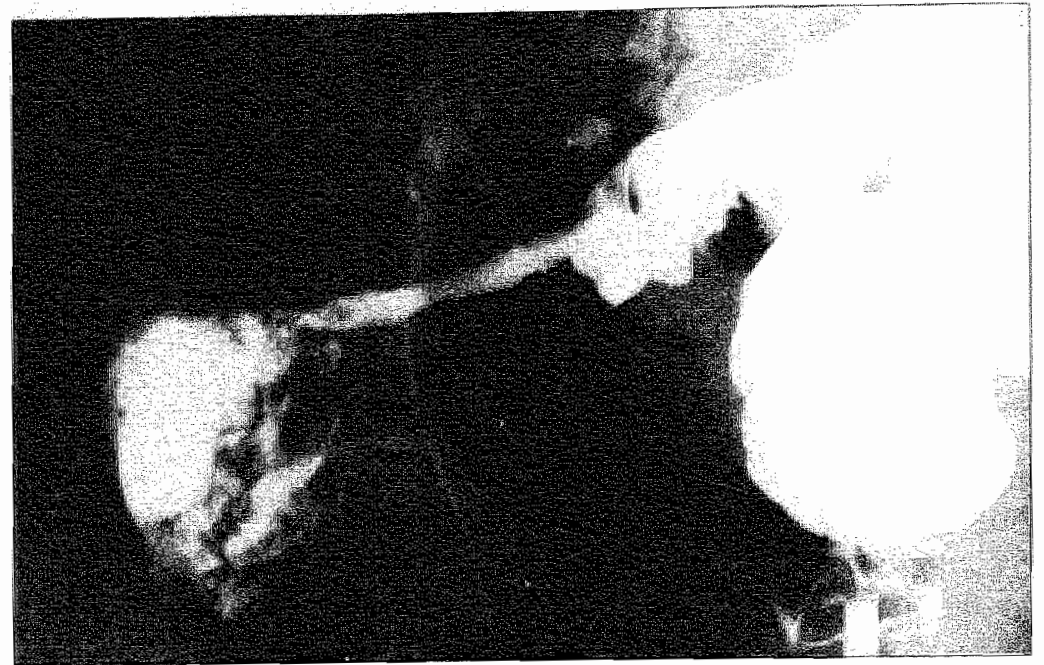

Fig. 5: Contrast radiography of the patient illustrating the fistula between the sigmoid and the right hip.

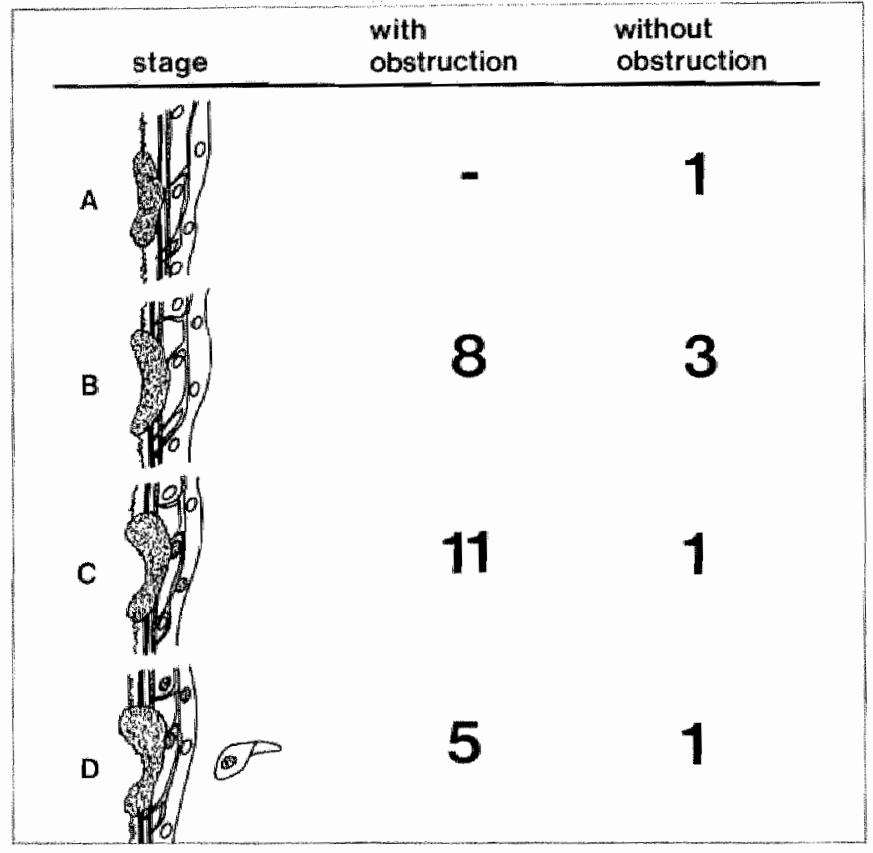

Fig. 6." Dukes staging of 30 patients with carcinoma undergoing an imraperative colon imigation

The second patient developed a burst abdomen and although no abcess or pus was found at il second operation, this patient was assessed as having a major infection.

Anastomotic leakage (table 6) occurred in 3 patients. In one of them (undergoing a high anterior resection) only a radiological leakage occurred without any clinical consequence. The first patient with a clinical leakage was operated on for an obstructing sigmoid carcinoma. At operation peritonitis catrcinomatosa was detected and a palliative sigmoid resection pertormed, together with a tube caecostomy. A clinical leakage occurred and a diverting colostony had to made at the hepatic flexure. This patient died from a myocardial infarction 4 days alter the second operation. The second patient with a clinical leakage was 
a 65 year old female. A fistula between the colon and the right hip caused persisting fever and severe illness [fig.5]. At first an abcess at the right hip was draned operatively and this was followed by total parenteral nutrition in order to bring the fistula to rest. This conservative treatment had to be interupted due to progressive deterioration of the pationt. A laparotomy was performed and the sigmoid (including the fistula) resected, after which a wo-layer anastomosis was created. Because of her extreme adiposity, and fearing the complications of a diverting colostomy, the surgeon perfomed a tube caecostomy. The anastomosis itself caused no technical problems alchough a clinical leakage subsequenty occurred and a colostomy nevertheless had to be performed. She died 130 days after admission and at post-montem examination an adenocarcinona from the right hip was found, filling the whole pelvic region, surrounding the rectosigmoid and stenosing the ureters.

In total, four patients died (table 6), three from cardiopulmonary complications. The last one (as described above) died due to complicarions of widespread carcinoma logether with clinical anastomotic leakage.

The Dukes staging of the 30 patients with carcinomata is shown in fig.6. More than hatf of the patients were in stages $C$ or $D$.

\section{Discussion}

\section{Management of the lesions of the righi colon}

For the management of obstructing lesions of the large bowel proximal to the splenic flexure (right colon), several preliminary operations can be employed prior to a resection. These are designed solely for the purpose of relieving obstruction.

Colonic decompression for non totally obstucting carcinomata (or in the case of Ogilvies syndrome) is an option [7-9] especially in very ill patients in whom another decompression operation is not possible. Although in these cases the hazard of overinflation can be prevented by using carbon dioxide instead of non absorbable gases for safe decompression and for avoiding the devastating complications of perforation, an extremely skilled endoscopist ought to be available.

Caecostomy -tube, or (preferably) diverting-can be useful as a minor procedure for an obstructing growth near to the splenic flexure, where the surgeon does not wish 10 carry out an inmediate extended right hemicolectomy and where a transwerse colostony will interfere with subsequent mobilization of the hepatic flexure if needed $[10,11]$.

lleotransversostomy with the purpose of reliewing obstruction by sidetracking faeces around the point of obstruction should only be used when there is an obstructing caucinoma of the ascending colon that is incurable because of extensive metastatic disease. If it is possible to resect and anastomose the colon as a primary procedure, this is better than ileotransversostomy [12, 13] both for the long term prognoses $[14]$ and for palliation.

Nowadays, there is general agreement that where the obstruction is due to a growth in the right colon, hemicolectomy is the treatment of choice, even in the presence of a laaded ascending and transverse colon, as the anastomosis is fashioned between the ileun and a relatively empty distal colon $[15-18]$. 


\section{Management of lesions of the left colon}

For lesions at or distal to, the splenic flexure (leficolon), a staged surgical management is the orthodox treament $[19-25]$ including diverting colostomy at the first operation, resection of the tumour at asecond and closing the stoma at a third operation.

The conviction that, whenever possibie, the disease should be removed at the first operation is gaining more and more ground. Our policy is in full accordance with the statement of Ceorge Crile $\sqrt{ } \mathrm{r}$. 261 discussing perforating lesions of the colon and the use of primary resection whenever possible: Most mportant is the elimination of the soure of conamination. If this is done the patient has a better chance of recovery than he does following a small operation, which diverts the faecal stream. It is the disease, not the operation, which causes the death and it is the first responsibility of the surgeon to eradicate the diseases. A Hartmant procedure or a Paul Mikulicz operation for left sided carcinomata or other colonic diseases offers a possibility of reaching this goal.

The mortality and, especially, the morbidity after the staged management [27] have encourtiged surgeons from 1950 onwards to find ways of performing a primary resection and anastomosis.

However, the problem of an unprepared colon at operation and the general rule not to perform an andstomosis in the left colon in these cases still had to be solved.

Primary resection and anastomosis without any bowel preparation has been done in the past with some disastrous results 1131. Although a few good results have been reported in these cases [28], the generall opinion of most surgeons is that a left-sided anastomosis should not be perfomed in an umprepared colon due to the unacceptably high anastomotic leakage rate and accompanying mortality 29]. To solve the problem of the unprepared colon in emergency surgery of the left colon, some authors introduced the "surgical colon preparation" removing the contaminated colon and performing an ileocolonic (rectal) anastomosis [30-37].

This is a well-conceived and satisfactory operation in some instances but has a few potential disadvantages: first, water absorption from the colon is quite drastically reduced and bowel motions tend to be semi-formed or loose and occur with increased frequency. Sccondly, if the patient is elderly and there has been some loss of sphincter tone, he or she may have difficulty in controlling the altered facal load. Thirdly, if an anastomotic leakage occurs $[38\}$ the patient is left with an ileostomy for the rest of his life.

In the literature only small sertes of funcrional results. mostly in young patients operated on for inflammatory bowel diseases (Crohn's disease, colitis), have been reported but larger series involving older patients reated in this way for cancer are necessary before acceptance of this method is justified. Kamm et al. [39] described the outcome of colectomy for severe idiopathic constipation in 44 women with a mean age of 34 years. Troublesome diarhoea was seen in almost $30 \%$ of these patients.

Our opinion at present is that (sub)total colectomy can only be justified in patients with carcinoma if perforation of the caecum has occurred due to distention proximal to an obstructing tumour. 


\section{Indications and contraindications}

The indications for using intraoperative colon irrigation before performing a one-stage operation are shown in table 1 . It is not suggested that a one-stage operation with intraoperative colon irrigation should be a routine procedure although it is acceptable for most cases of left colonic obstruction provided that selection requirements and technicall demands are met.

The general factors which influence any decision not to proceed with colonic irrigation and primary anastomosis include circullatory instability, poor general condition, deficien nutritional status and immunosuppression.

Primary anastomosis has especially to be avoided both in patients who have colonic resection in the presence of advanced peritonitis and interloop abcesses, and when the cur ends of the bowel appear unhealthy.

Two patients in this study with sigmoid resections developed clinical leakage, irrespective of the fact that the anastomoses had been technically easy to perform. Both these patients had peritonitis carcinomatosa. After this experience, and knowing the influence of tumours in the vicinity of an anastomosis on healing [40], performance of a primary anastomosis in these patients is not advised. Anastomoses in patients with liver metastases alone (withour peritonitis carcinomatosa) did not show impaired healing.

\section{Duration of the procedure}

In this study it took 20-80 minutes (mean 40 minutes) to complete the peroperative lavage and this, added to the time required for the resection and anastomosis, meant that patients were anesthetized for between two and three hours.

It should be noted that in all these patients (except for 3 who were operated on immediately after admission) there was enough time to analyse the cardiopulmonary and nutritional states, and a considered preoperative judgement was almost always possible.

In the patients with a relatively stable circulatory state and in whom no intra-abdominal contraindications were present, the extra time for intraoperative colon irrigation was well spent because in a high percentage a further operation in these mostly elderly patients wats avoided. With contemporary anaesthetic techniques, the additional time dicl not seem to expose the patients to any marked increase in risk.

\section{Colostomy}

Construction of a colostomy, even though this is considered a small operation, leads to at reduction in the quality of life in elderly patients $[41,42]$. In this study, an one- stage operation was possible and safe in all but one patient (in whom intraoperative colon irrigation thad been used to get rid of conservatively untreatable faecal impaction).

Only two patients received a diverting colostomy. In most patients a tube caecostomy wass used in order to decompress the anastomosis. However, the tube caecostomy could be omitted in patients in whom the anastomosis was above the peritoneal reflection, was created with sound surgical technique and was covered by omentum. In this study, using intraoperative colon irrigation and tube caecostomy a defunctioning colostomy could be avoided with reasonable safety. In difficult anastomoses a diverting colostomy may still be 
the method of chorce but this was employed only in two patients. As an alternative for a diverting colostomy, a transanal decompression [43]. colonic bypass 44 ] or a transcaecal ileostomy as reported by Simpson and Srivastava [45] should be kept in mind.

\section{Staged resection; mortality and morbidity}

In general, obstruction is present in approximately $20 \%$ of all patients adminted for colonic carcinoma [46]. The chance of dyng from obstruction is said to be belween 20 to $30 \%$, inespective of the operative policy [47]. In the older patients (>70 years) the chance of dying from obstruction (40\%) is even higher [46].

Pollock et al. [48] reported a mortality of $44.7 \%$ (17 out of 38 ) after diverting colostomy had been performed with a view to a later resection of the obstructing lesions.

The mortality was $33.3 \%$ in patients in whom a Harmann or Mikulicz procedure load been performed.

Irvin et all. [491, in a retrospective analysis of 66 patients with malignant colon obstruction, noted a mortality rate of $38 \%$ within 30 days of operation. A prospective multicentre study of 444 obstructing left colon cancers 147$]$ showed an in-hospital mortality of $24.3 \%$.

Bakker et al. $[50\rfloor$ reported a mortality rate of $37.3 \%$ (22 out of 59 parients) after the Hartmann procedure. The colorectal continuity in the surviving 37 patients was subsequently restored in only 12 patients leaving 25 patients with a permanent colostomy. Stomal necrosis or retraction occurred in 12 patients and leakage of the rectal stump in 3.

Wara et al. [22] in reporting the outcome of three-stage managenent of complicated diverticular disease of the sigmoid colon, showed that every step in the staged procedure had its own morbidity rate. Even if the complications were not serious, they debilitated the patient steadily and prolonged the course of the disease. Together with advanced age this may have been the main reason why an unexpectedly high proportion of patients (46 out of 83) did not reach the final stage of the planned treatment.

If the mortality pencentage (mean $30 \%$ ) after staged operation (including resection of the tumour and closing the colostomy) is compared with the mortality percentage (mean $10 \%$ ) after intraperative colon irrigation and the one-stage opertion, the latter is always lower. This lower montality percentage can be partially explained by the method of patient selection and therefore some of the results expressed migh not be strictly comparable.

It is not the intention to question the feasibility or safety of staged management. On the contrary, the Hartmann procedure is still the method of choice fol" left sided colonic disease if there are contrandications to performing intraperative colon irrigation followed by the onc-stage operation. It is the excessively dogmatic adherence to the principles of a threestage approach which is criticized, especially when a safe one-stage operation is possible.

In this study 4 out of 41 patients died $(9.8 \%$ ). This result with intraoperative colon irrigation compares untavourably with the death rates $3 \%[51], 4 \% \quad 152]$ and $3 \% \quad 1531)$ presented by some surgeons. but is comparable to the results of certain other workers $[48,54]$ being $17.1 \%$ and $8.7 \%$ respectively. 


\section{Wound infection}

The wound infection rate in this study was higher than that of other groups, but comparable with that of Pollock [48], who used the same definitions.

With the hypothesis that antibiotics administered intravenously at the induction of anaesthesia could not optimally combat the inoculation of organisms from the colon inio the wound during surgery, a method of acute colonic decontamination was studied and recently introduced in this Institute. This technique is discussed in chapter 10.

New instruments have been developed in order to make the procedure even safer for most surgeons (Chapter 6).

\section{Prognosis}

Patients with obstructions have a poorer prognosis in the long term. As shown by the Lirge Bowel Cancer Project [47] (reporting the data of 713 patients with obstructive colon carcinoma) only 25 percent of patients with obstruction survived atter 5 years compared to $45 \%$ in the non-obstructed group.

Fielding and Wells and other workers $[4,55,56]$ suggested that patients treated by primary resection might live longer. After primary and staged resections, they noted a survival of $50 \%$ and $25 \%$ respectively. Due to the small numbers of patients they studied (50 in all), their suggestion is not conclusive. Moreover, it is not supported by the findings of the Large. Bowel Cancer Project, in which no significant difference in 5 year survival was found. In our study more than half the patients operated on for obstructed carcinoma had advanced disease classified as Dukes C or D and this might reflect the poor outcome in these patients.

\section{Conclusions}

- The intraoperative colon irrigation procedure enables us to create an elective environment at "non elective" times in colorectal surgery, permitting a safe one-stage operation in most patients with obstructions of the left colon.

With the aid of the rectal tube, intraoperative colon irrigation can be performed easily in ill or unprepared patients with non obstructing lesions such as tumours, perforations or fistulae.

- If certain criteria are fulfilled, this procedure enables primary resection and anastomosis to be performed with low operative mortality and complication rates.

It offers the patient:

- no stomal problems

- one-stage procedure with single hospitalisation

- shorter hospital stay with financial savings

- better quality of life (taking into consideration the short 5-year expectation in patients with obstructing carcinoma). 


\section{References}

1. Irvin TT, Golligher "WC.

Actiology of distupution of intestinal anastomoses.

Br J Surg 1973;66:461-4.

2. Hewitt J, Rigby J, Reeve J, Cox AG.

Whole-gut itrigation in preparation for large bowel-surgery.

Luncet $1973 ; 2: 337-40$.

3. Hughes ES.

Mortality of acute large-bowel obstruction.

Br J Surg 1966:53:593 4.

\section{Fielding LP, Wells BW.}

Survival after primary and after staged resection for large bowel obstuction caused by cancel:

Br. Surg 1974:61:16-8.

\section{Lloyd-Davies OV.}

Lithotomy - Trendelenburg position for resection of rectum and lower pelvic colon.

Lancet $1939 ; 2: 74-6$.

6. Jones PF, Matheson NA.

Operative decompression in intestinal obstruction.

Lancet 1968;1:1197-8.

\section{Martin FM, Robinson AM Jr, Thompson WR.}

Therapeutic colonoscopy in the treatment of colonic pseudo-obstruction.

A.m Surg 1988:54:519-22.

8. Bode WE, Beart RW Jr, Spencer RI, Culp CE, Wolff BG, Taylor BM.

Colonoscopic decompression for acute pseudo-obstruction of the colon (Ogilvie's syndrome). Report of 22 cases and review of the literature.

Am J Surg 1984; 147:243-5.

\section{Welch CE.}

Intrapentive techniques in large bowel obstrtion: methods of management without bowel resection.

In: Fielding LP, Welch J, eds. Intestinal abstruction. Edinburgh:

Churchill Livingstone, 1987: 127-38.

\section{Muir EG.}

Safery in colonic resection.

Proc R Soc Med 1968;61:401-8. 
11. Goligher JC, Smiddy FG.

The treatment of acute obstruction or perforation with carcinoma of the colon and rectum. Br J Surg 1957:45:270-4.

\section{Savage PT.}

The management of acute intestinal obstruction. A critical review of 179 personal cases.

BrJ Surg 1960;47:643-54.

\section{Irvin TT, Greaney MG.}

The treatment of colonic cancer presenting with intestinal obstruction.

Br J Surg 1977;64:741-4.

\section{Gregg RO.}

The place of emergency resection in the management of obstructing and perforating lesions of the colon.

Surgery 1955;37:754-61.

\section{Dutton JW, Hreno A, Hampson LG.}

Mortality and prognosis of obstructing carcinoma of the large bowel.

Am J Surg 1976;131:36-41.

\section{Morgan WP, Jenkins N, Lewis P, Aubrey DA.}

Management of obstructing carcinoma of the left colon by extended right hemicolectomy. Am J Surg 1985;3:327-9.

\section{Smithers BM, Theile DE, Cohen JR, Evans EB, Davis NC.}

Emergency right hemicolectomy in colon carcinoma: a prospective study.

Aust N Z J Surg 1986:56:749-52.

\section{Steffen C, Bokey EL, Chapuis PH.}

Carcinoma of the splenic flexure.

Dis Colon Rectum 1987;30:872-4.

19. Botsford TW, Zollinger RM, Hicks R.

Mortality of the surgical treatment of diverticulitis.

Am J Surg 1971;121:702-5.

\section{Welch JP, Donaldson GA.}

Management of severe obstruction of the large bowel due to malignant disease.

Am J Surg 1974;127:492-9.

21. Carson SN, Poticha SM, Shields TW.

Carcinoma obstructing the left side of the colon.

Arch Surg 1977:112:523-6.

\section{Wara P, Soerensen K, Berg V, Amdrup E.}

The outcome of staged management of complicated diverticular disease of the sigmoid colon. Acta Chir Scand 1981;147:209-14. 
23. Krukowski $Z$ H, Matheson NA.

Energency surgery for diverticular disease complicated by generalized and faecal peritonitis: a review.

Br I Surg 1984:71:921-7.

24. Clark I, Hall AW, Moossa AR.

Treatment of obstructing cancer of the colon and rectum.

Surg Gynecol Obstet 1975;141:541-4.

\section{Fielding LP, Stewart-Brown S, Blesovsky L.}

Large-bowel obstruction caused by cancer: a prospective study.

Br Med J 1979;2:515-7.

26. Crile GB Ir.

Dingers of conservative surgery in abdominal emergencies.

Surgery $1954 ; 35: 122-3$.

\section{Wangensteen $\mathrm{OH}$, Toon RW.}

Primary resection of the colon and rectum with particular reference to cancer and ulcerative colitis.

Am J Surg 1948;75:384-404.

\section{Mealy K, Salman A, Arthur G.}

Definitive one-stage emergency large bowel surgery.

Br J Surg 1988;75:1216-9.

\section{White CM, Macfie J.}

Immediate colectomy and primary anastomosis for acute obstruction due to carcinoma of the left colon and rectum.

Dis Colon Rectum 1985;28:155-7.

\section{Drapanas T, Pennington DG, Kappelman M, Lindsey ES.}

Emergency subtotal colectomy: preferred approach to management of massively bleeding diverticular disense.

Ann Surg 1973:177:519-26.

\section{Fazio V, Turnbull RB Jr, Goldsmith MG.}

Ileorectal anastomosis: a safe surgical technique.

Dis Colon Rectum 1975:18:107-14.

\section{Nemer FD.}

The dilemma of preservation of the rectum: subtotal colectomy and ileorectal anastomosis in inflammatory disease of the bowel.

Dis Colon Reclum 1977:20:652-4.

\section{Klatt GR, Martin WH, Gillespie JT.}

Subrotal colectomy with primary anastomosis without diversion in the treatment of obstructing carcinoma of the left colon.

Am J Surg 1981:141:577-8. 
34. Deutsch AA, Zelikovski A, Sternberg A, Reiss R.

One-stage subtotal colectomy with anastomosis for obstructing carcinoma of the left colon. Dis Colon Rectum 1983;26:227-30.

35. Wedell HJ, Banzhaf G, Meier zu Eissen P, Castrup W, van Calker H.

Die notfallmassige Colektomie mit primärer Anastomose beim obturierenden linksseitigen

Coloncarcinom.

Chirurg 1983:54:582-8.

36. Adloff M, Arnand JP, Ollier JC.

Emergency one-stage subtotal colectomy with anastomosis for obstructing carcinoma of the left colon.

Dig Surg 1984:1:37-40.

37. Hughes ES, McDermott FT, Polglase AL, Nottle P.

Total and subtotal colectomy for colonic obstruction.

Dis Colon Rectum 1985;28:162-3.

38. Terry BG, Beart RW Jr.

Emergency abdominal colectomy with primary anastomosis.

Dis Colon Rectum 1981;24:1-4.

39. Kamm MA, Hawley PR, Lennard-Jones JE.

Outcome of colectomy for severe idiopathic constipation.

Gut 1988;29:969-73.

40. Graaf PW de.

The influence of tumorgrowth on woundhealing. An experimental study in the rat [Thesis].

Leiden: State University of Leiden, 1981.99 pp.

41. Mirelman D, Corman ML, Veidenheimer MC, Coller JA.

Colostomies-indications and contraindications: Lahey Clinic experience, 1963-1974.

Dis Colon Rectum 1978;21:172-6.

42. Pittman DM, Smith LE.

Complications of colostomy closure.

Dis Colon Rectum 1985:28:836-43.

43. Hardy TG Jr; Stewart WR, Aguilar PS.

Prevention of colostomy in partial colonic obsuruction by intraoperative rectal tube irrigation.

Dis Colon Rectum 1985;28:122-7.

\section{Ravo B, Ger R.}

A preliminary report on the intracolonic bypass as an alternative to a temporary colostomy. Surg Gynecol Obstet 1984;159:541-5.

\section{Simpson A, Srivastava VK.}

Temporary transcaecal ileal diversion in prevention of anastomotic leak in planned colonic surgery (an alternative to proximal colostomy).

Br J Surg 1975:62:243 5. 


\section{Waidron RP, Donovan $1 \mathrm{~A}$.}

Mortality in patients with obstructing colorectal cancer.

Ann R Coll Surge Engl 1986;68:219-21.

\section{Phillips RK, Hittinger" R, Fry JS, Fielding LP.}

Malignant large bowel obstruction.

Br J Surg 1985;72:296-302.

\section{Pollock AV, Playforth $M J$, Evans $M$.}

Peroperative lavage of the obstructed left colon to allow safe primary anastomosis.

Dis Colon Rectum 1987:30:171-3.

\section{Irvin TT, Greaney MG.}

Duration of symptoms and prognosis of carcinoma of the colon and rectum.

Surg Gynecol Obstet 1977; 144:883-6.

\section{Bakker FC, Hoitsma HF, Otter G den.}

The Hartmann procedure.

Br J Surg 1982;89:580 2.

\section{Radcliffe AG, Dudley HA.}

Intraperative antegrade irrigation of the large intestine.

Surg Gynecol Obstet 1983;156:721-3.

\section{Thomson WH, Carter SS.}

On-lable lavage to achieve safe restorative rectal and emergency left colonic resection without covering colostomy.

$\mathrm{Br} J$ Surg 1986;73:61-3.

\section{Weaver PC, Khawaja $\mathrm{HT}$.}

Intra-operative colonic irrigation (letter).

Br J Surg 1986;73:83-4.

\section{Koruth NM, Hunter DC, Krukowski ZH, Matheson NA.}

Immediate resection in emergency large bowel surgery: 7 year audit.

Br I Surg 1985;72:703-7.

\section{Fisher ER, Turnbull RB Jr.}

The cytologic demonstration and significance of tumour cells in the mesenteric venous blood in patients with carcinoma of the colon and rectum.

Surg Oynecol Obstet 1955:100:102-6.

\section{Engell HC.}

Cancer cells in the circulating blood: A clinical study on the occurrence of cancer cells in the peripheral blood and in venous blood draining the tumour area at operation.

Acta Chir Scand 1955; Suppl 201. 


\section{Chapter 6}

\section{Development of new instruments and subsequent modifications to the intraoperative colon irrigation technique}

A professional video film (WHS/U-matic) was made in order to demonstrate the techniqu. of intraoperative colon irrigation as described in this chapter.

The use of the irrigation needle and drainage tube for obstructing lestons of the lof colon is illustrated, as is the rectal tube for irrigation of the colon in non-obstming disease. The method of intraoperative colon decontamination is also shown in this fim.

\section{Introduction}

During the intraoperative colon irrigation procedure as described by Dudley in 1980 [1], leakage either at the site of the Foley catheter on at the site of the tube could not always be prevented. To overcome these problems, new instruments have been developed in order to make the procedure safer and easier to perform.

To minimise the bacterial inoculum during operation, a new method of intraoperative colon decontamination was studied experimentally and it is nowadays used.

\section{New instruments}

\section{Irrigation needle}

During intraoperative colon irrigation, the occurrence of lakage of intestinal contents at the site of the Foley catheter could not always be prevented. If the purse-string around the Foley catheter was too tight, then stenosis in the catheter occcured, decreasing the influx of intrgation fluid. On the other thand, if the purse-string was not tight enough leakage could occur during irrigation [fig. 1].

An irrigation needle was developed, replacing the Foley catheter. The needle, which has an inner diameter of $3 \mathrm{~mm}$ [figs. 2 and 3 ] is introduced without a tomy with the aid of the trocar, preferably through the base of the appendix. In the absence of the appendix the needle can be brought in through the ileum or caput of the caecum after making a pursestring surure.

The needle is fixed on to the base of the appendix by simple uigh ligation. To prevent slipping off, the needle is also fixed with this ligature ffig. 4]. Because the needie is totally rigid hardly any leakage can occur after tight fixation. 


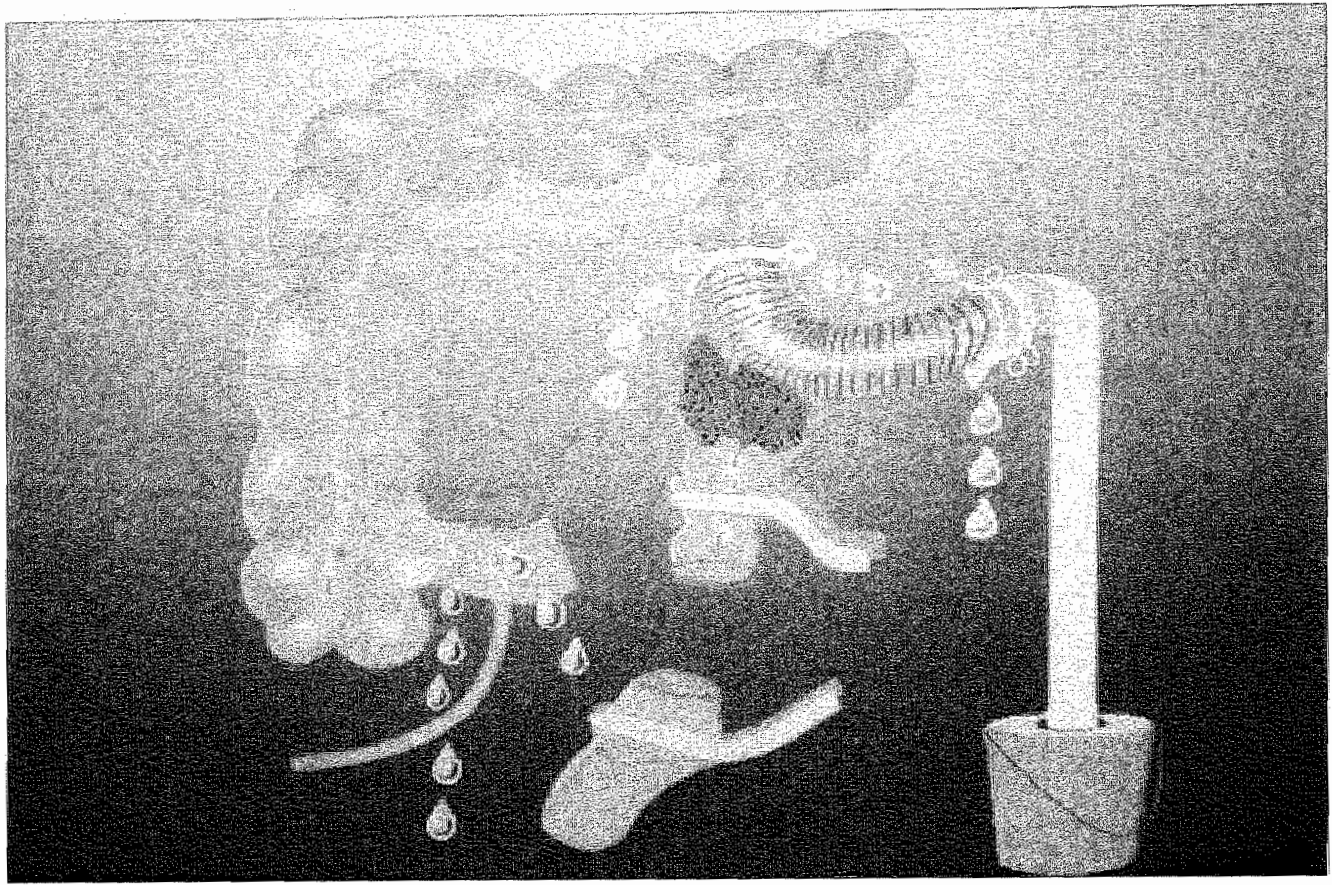

Fig. 1: Probable leakage sites during the performance of the original intraperative colon irrigation procedure.

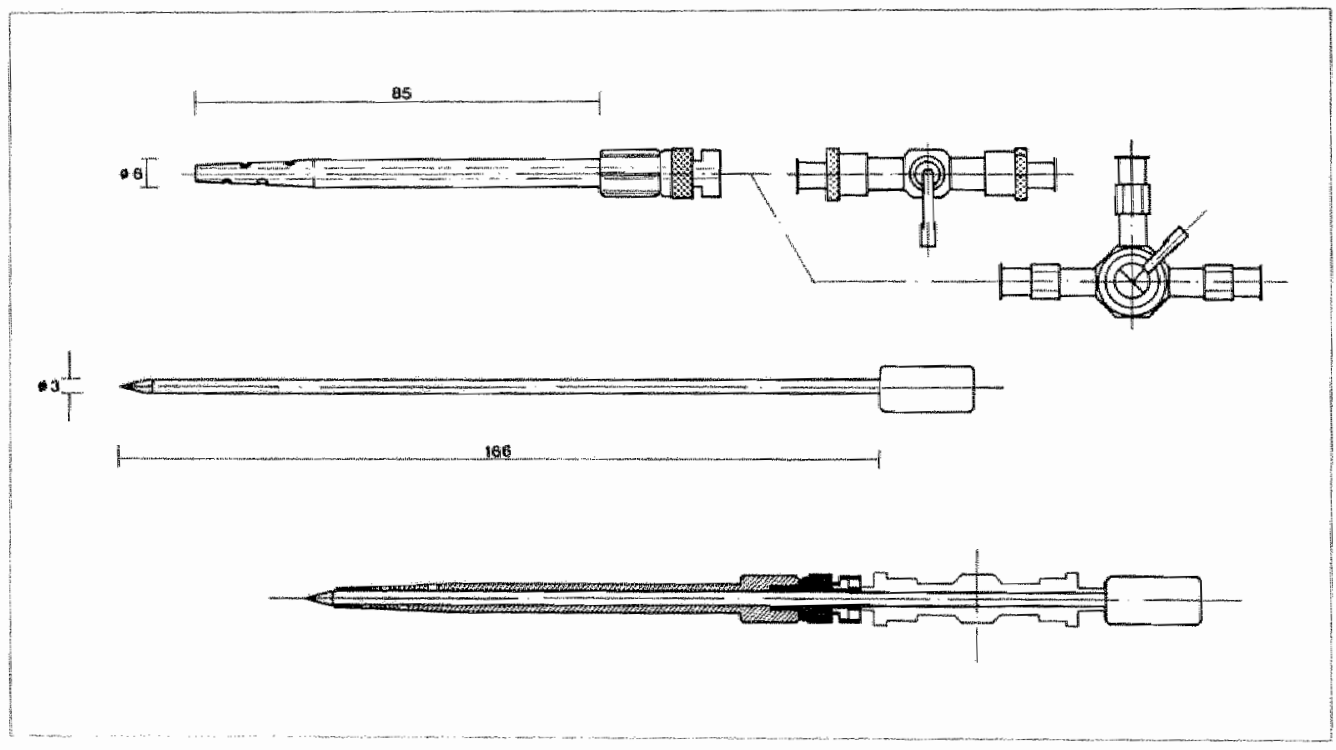

Fig. 2: Schematic illustration of the irrigation needle with one or two Luer-lock connections. 


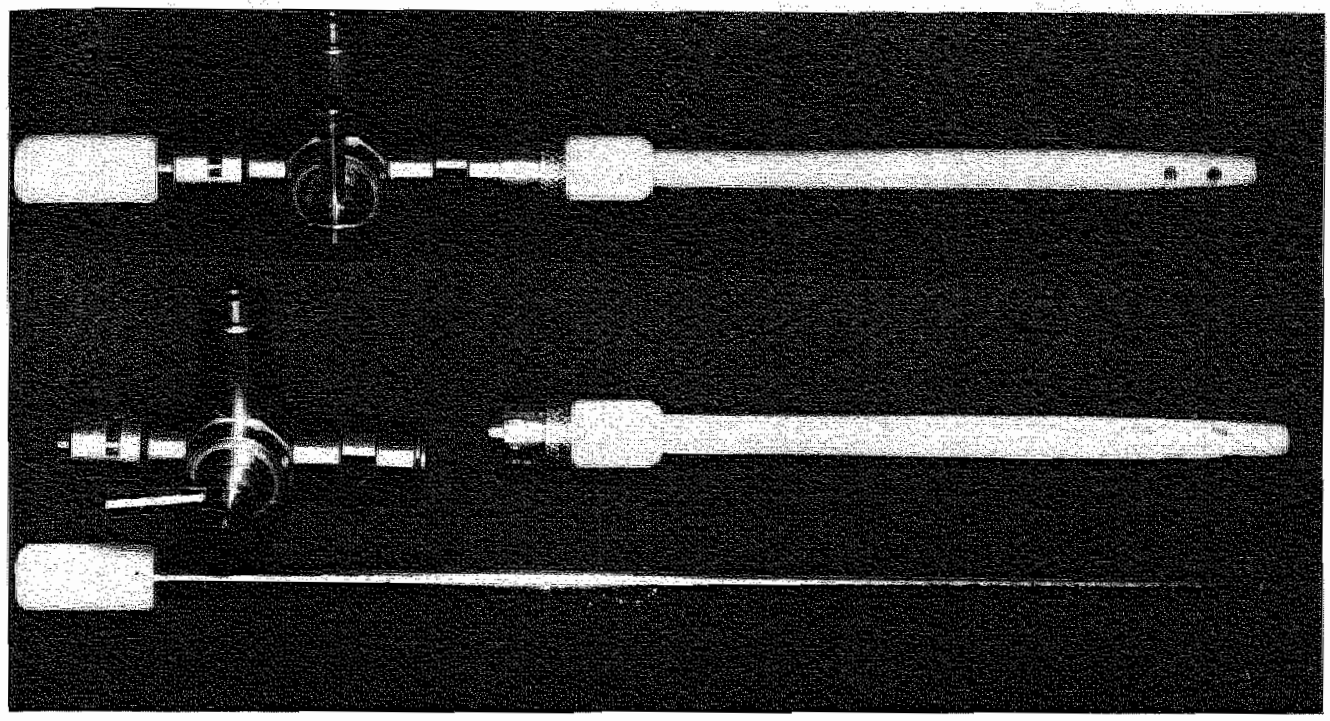

Fig. 3. Irrigation needle with two Lacr-lack connections with trocar.

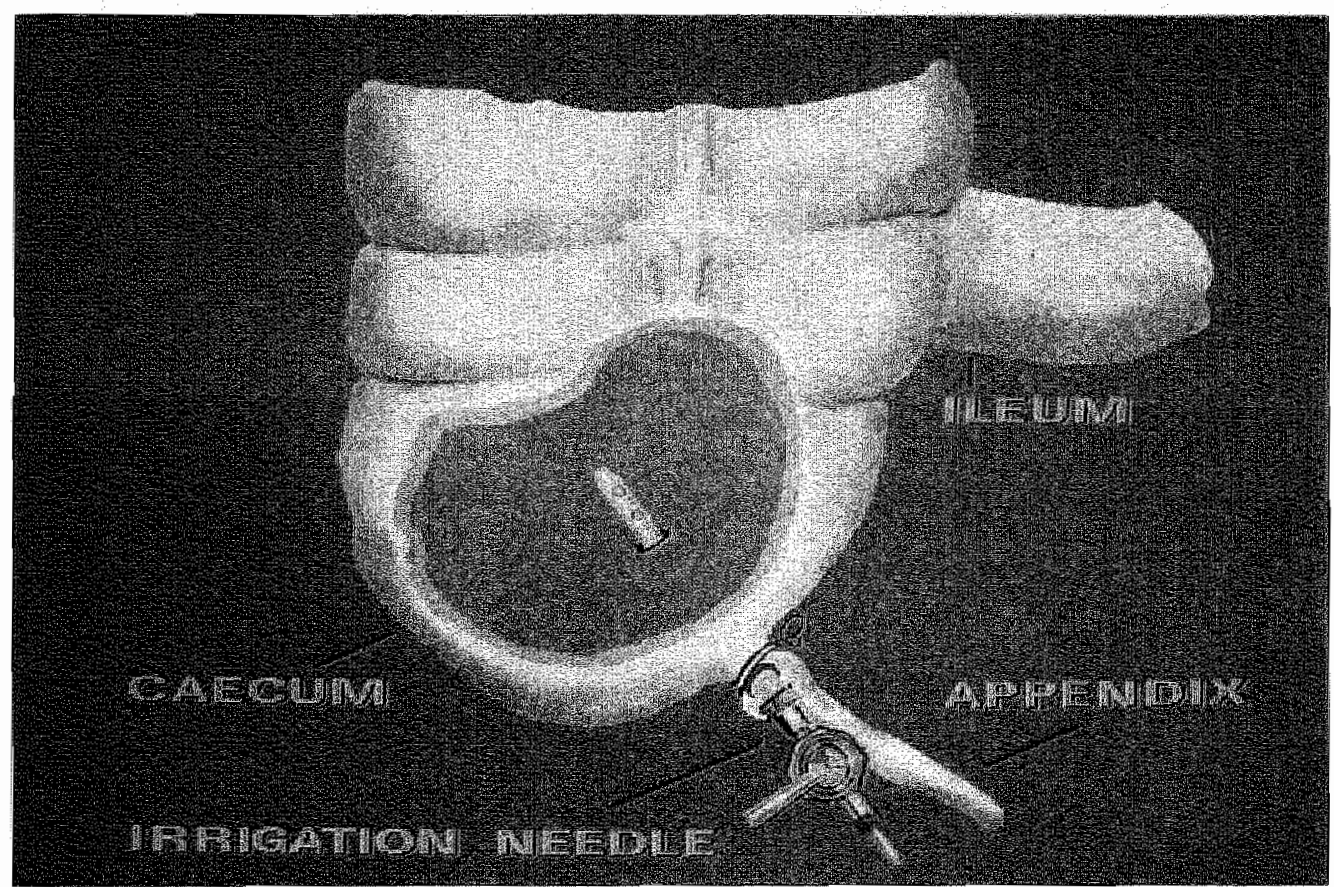

Fig. 4: Irrigation needle introduced through the appendix and fixed by simple vigh ligation. 


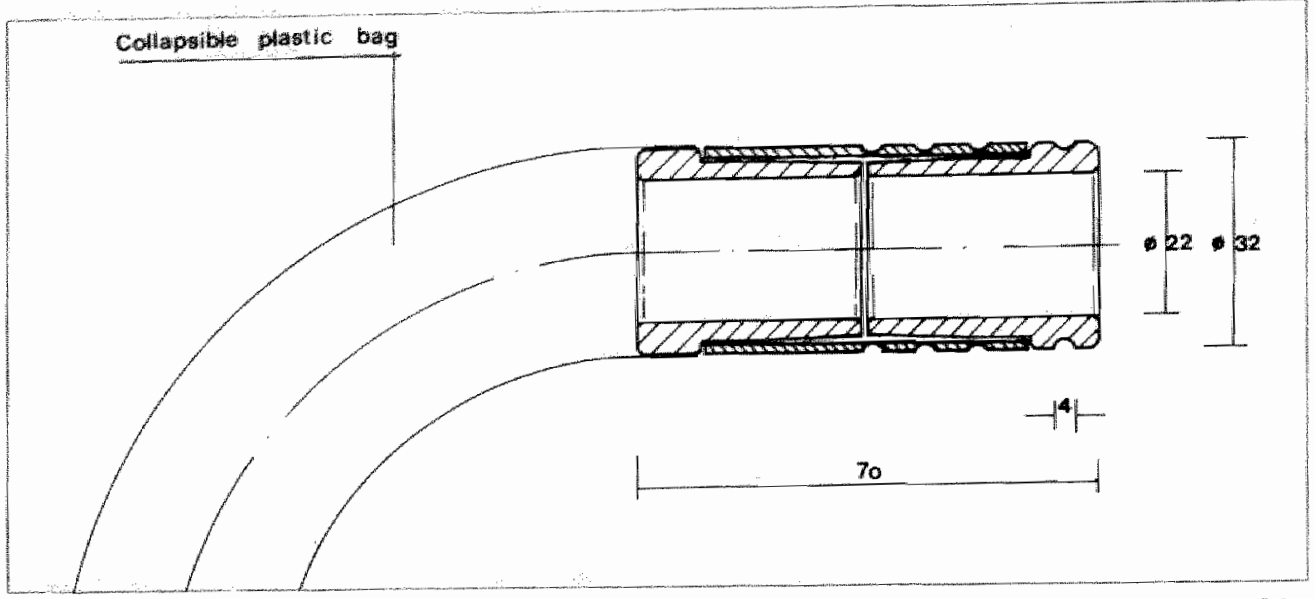

Fig. 5. Schenatic illustration of the irrigation rigid drainage tube in which the collapsible plastic bag is fixed so that leakage is almosimpossible.

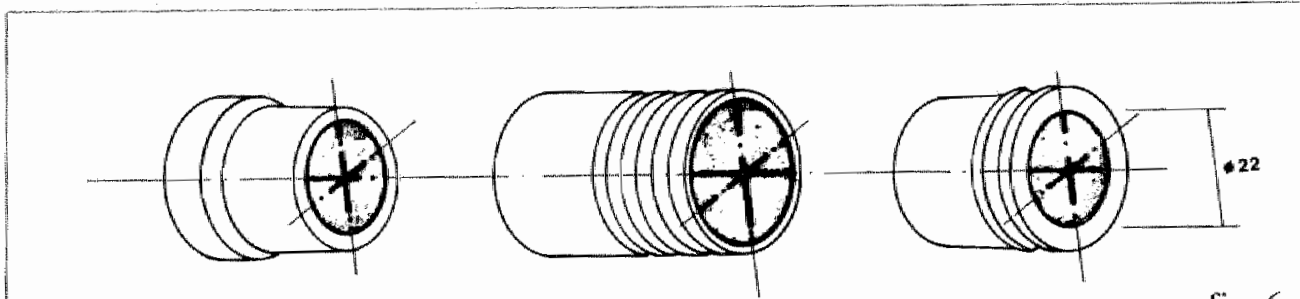

fig. 6

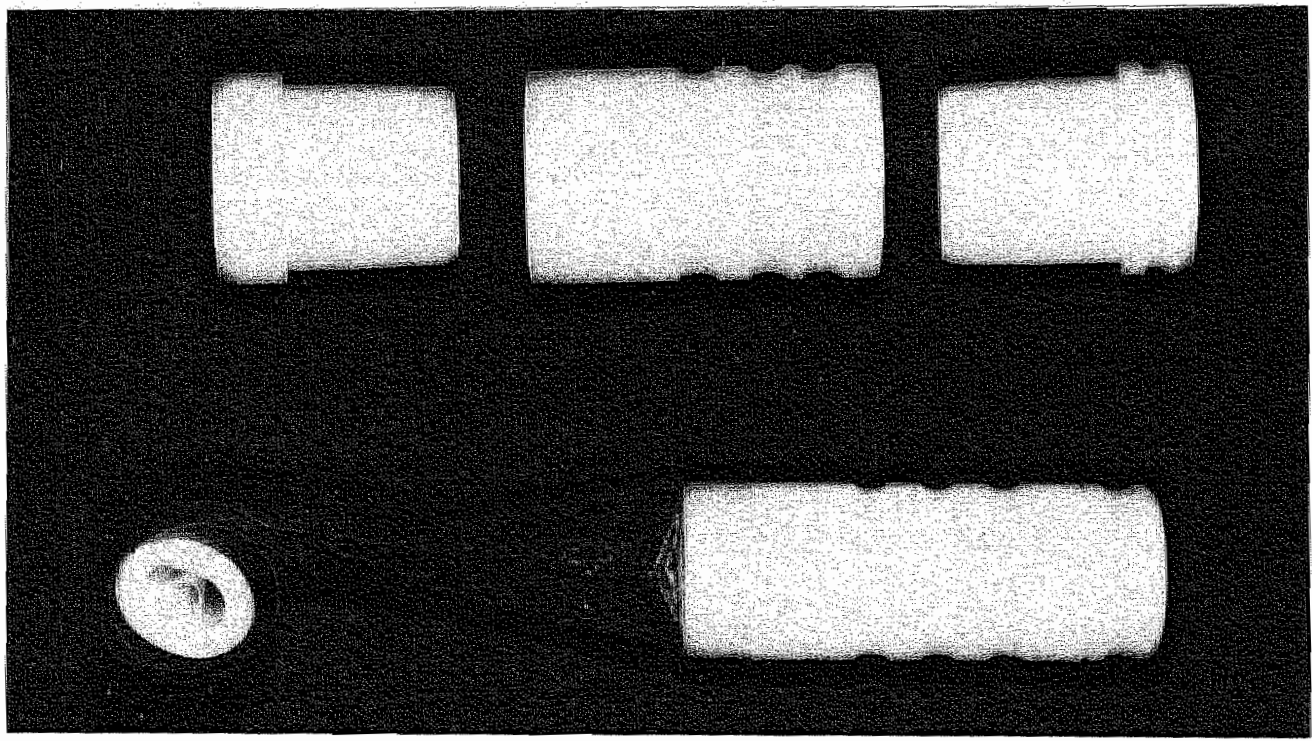

Fis. 6. The rigid drainage twbe consists of 3 pars in which the collapsable plastic bag can be fived withow adheswe.

Fig. 7: The imigation drange tube. 


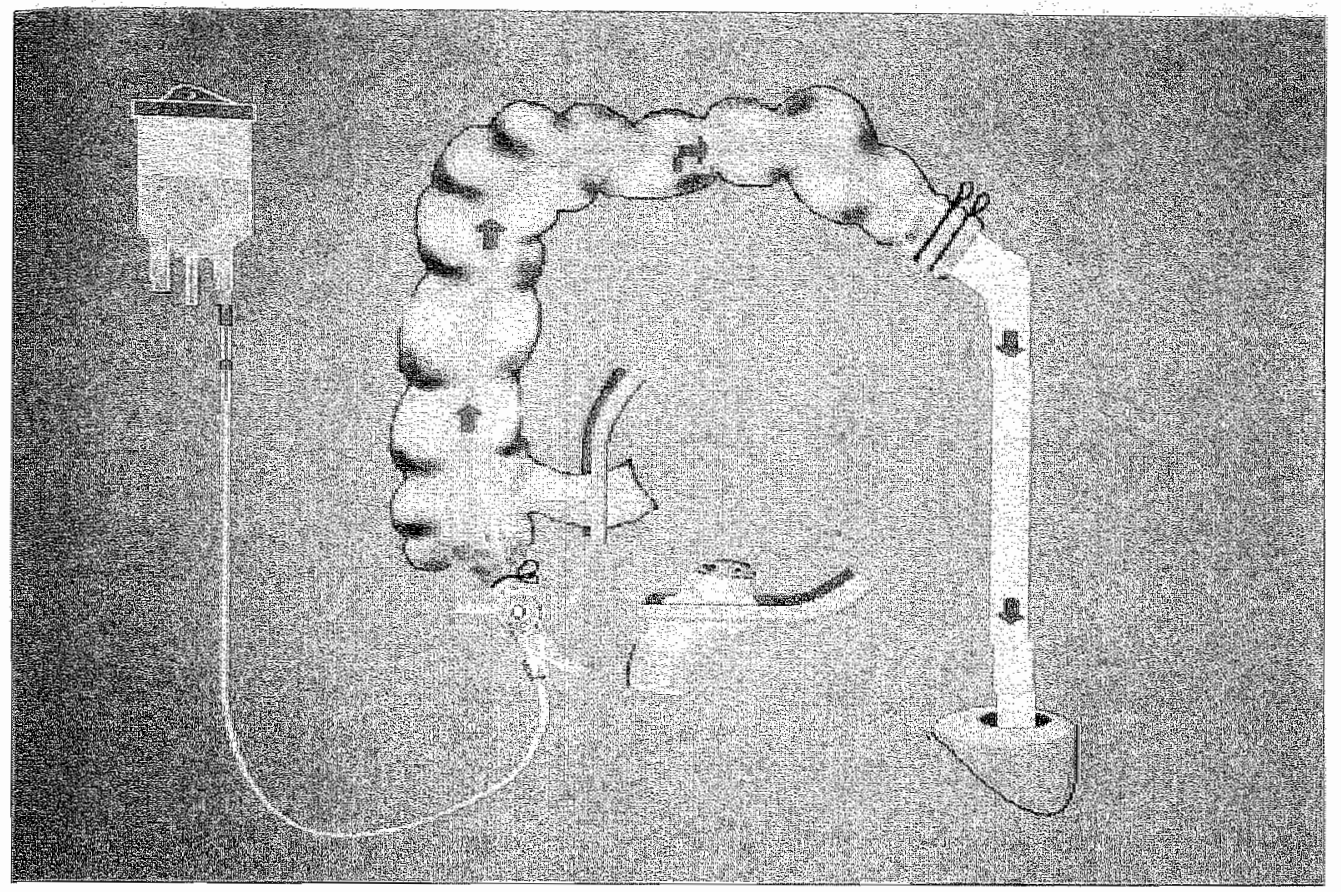

Fig. 8. Fixation of the drainage tube at the proximal resected end and ligation with two cotton tapes. Colonic irrigation is carried out through the irrigation needle.

After introduction of the needle, the trocar is removed and the tap closed to prevent faecal spillage. Either one or two infusion systems can be connected to the needle for irrigation. depending on the presence of one- or three-litre plastic bags of Hartmann solution. If threelitre bags are available, one connection alone will be sufficient to perform a rapid irrigation.

\section{Irrigation drainage tube}

The second place where leakage could occur was the connection of the anaesthetic tubing, either at the site of its fixation to the colon or to the plastic bag [fig.1]. A special irrigation drainage tube has been developed, replacing the difficult to handle anaesthetic tubing. A very light totally non-collapsible material (Delrin ${ }^{R}$ ) has been used to consiruct this tube. The collapsible plastic bag in the irrigation drainage tube is fixed without adhesive, in such a way that leakage at the site of the plastic bag is practically impossible [figs. 5, 6, 7 and 8]. Due to the fact that the tube is rigid and is furnished with grooves, tight ligation is feasible without any chance of the tube slipping off the colon during irrigation. The plastic bag is cut to the desired length and led to a bucket beside the table. 


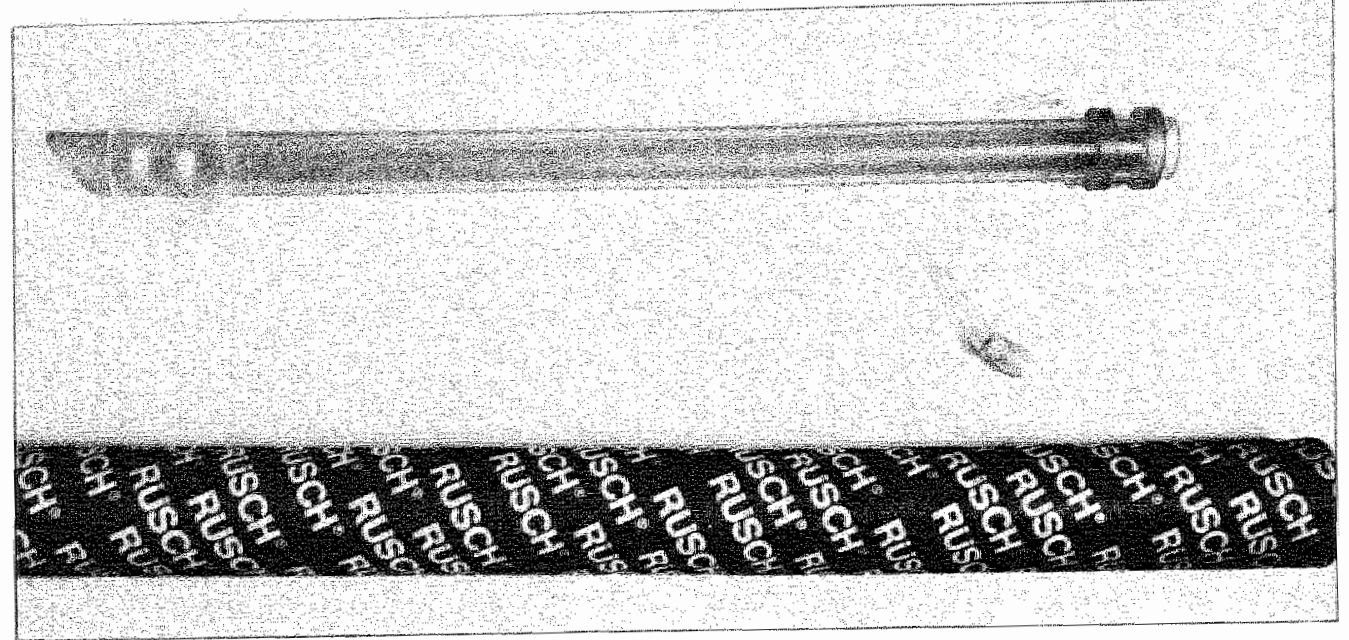

Fig. 9: The newly developed rectal wabe.

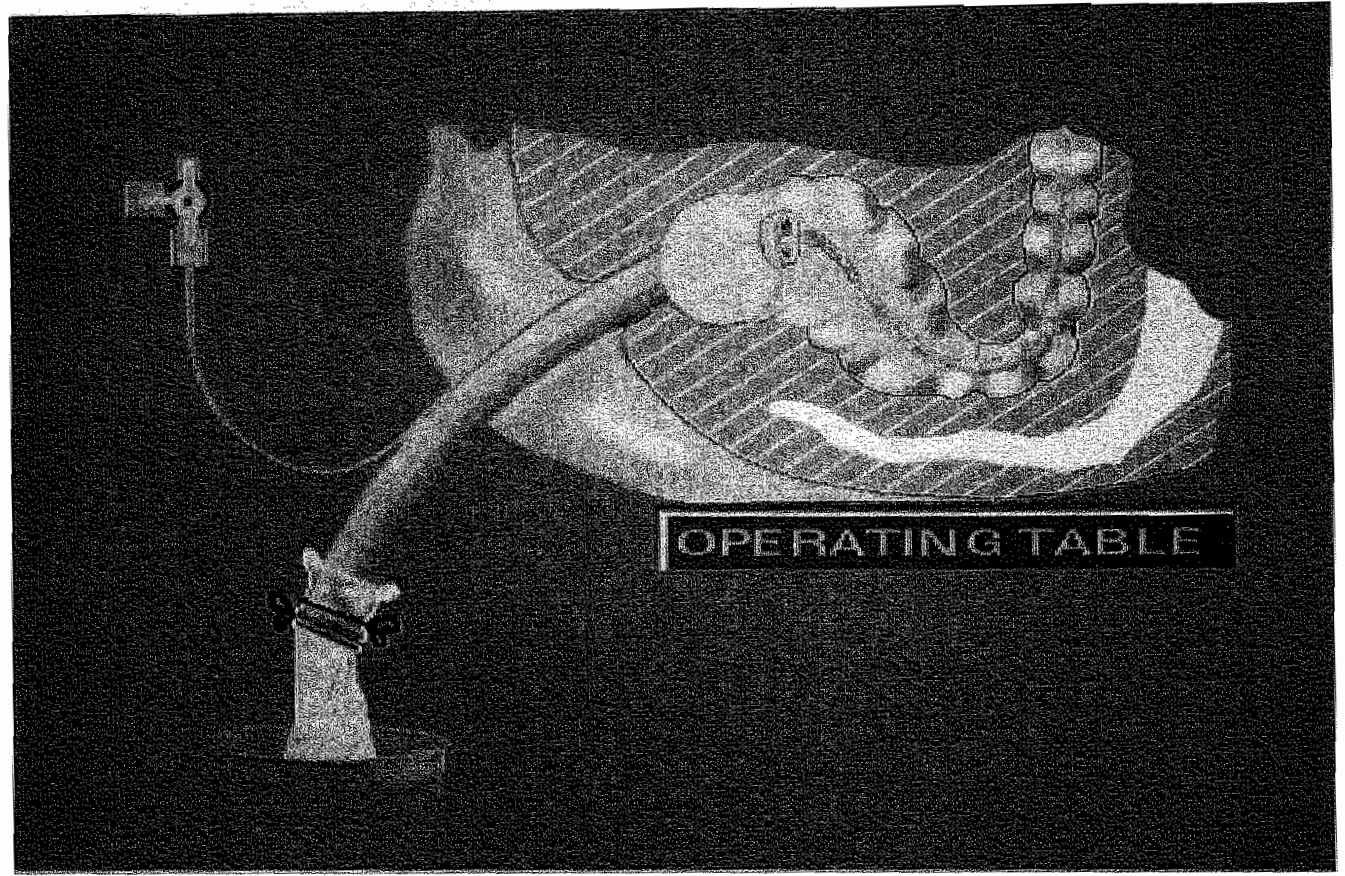

Fig. 10: The balloon of the tube occludes the amus tolally, preventing any spillage during intraprative colon irrigation for mon-obsurang lesions. 


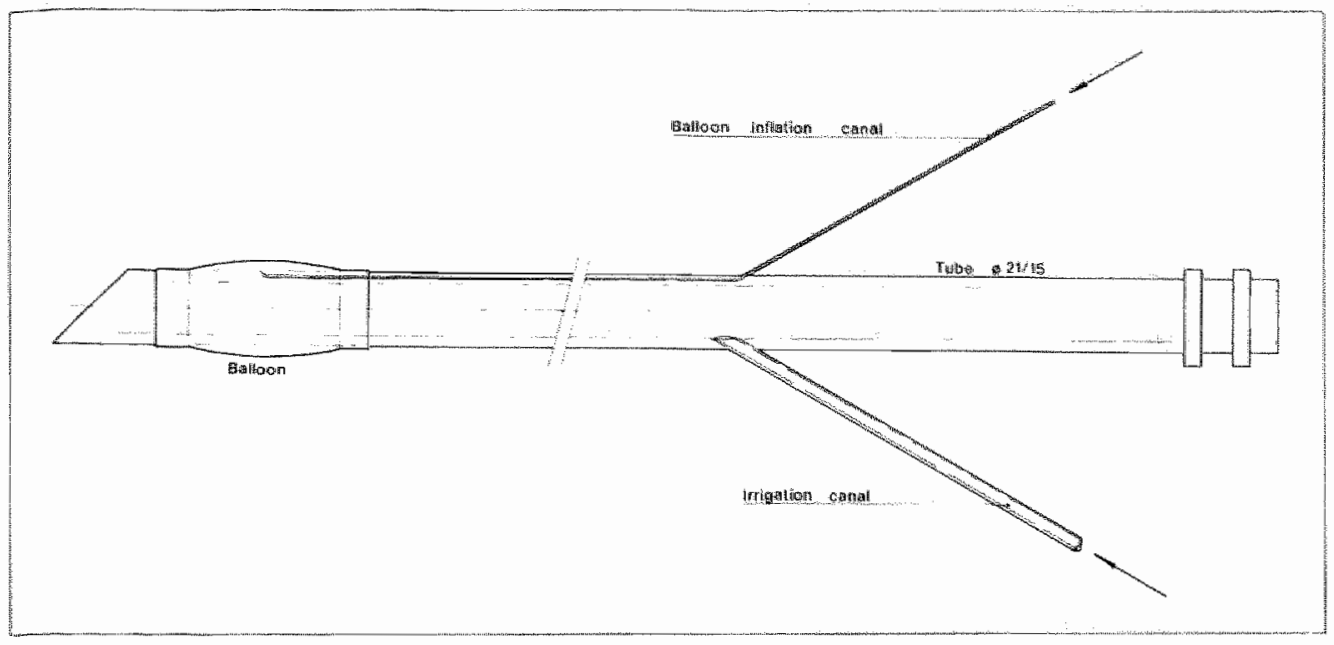

Fig. 11: Schema: Via the imbuilt irrigation canal in the tube instillation of cancericidal fluid, testing of the anastomosis or rectal washout is feasible.

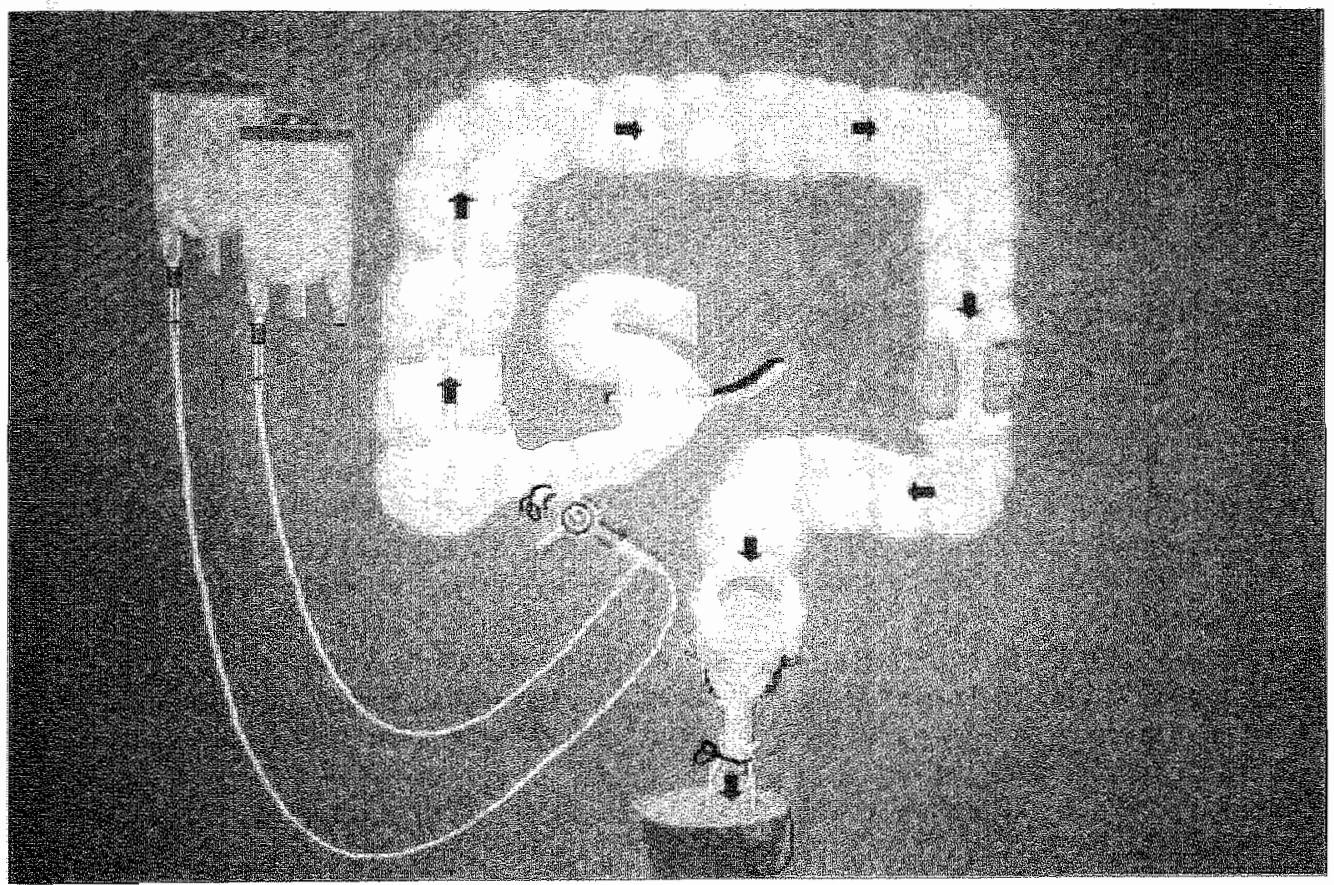

Fig. 12: Intraoperative colon irrigation procedure in non-obstucting lesions, with the aid of the rectal tube. 


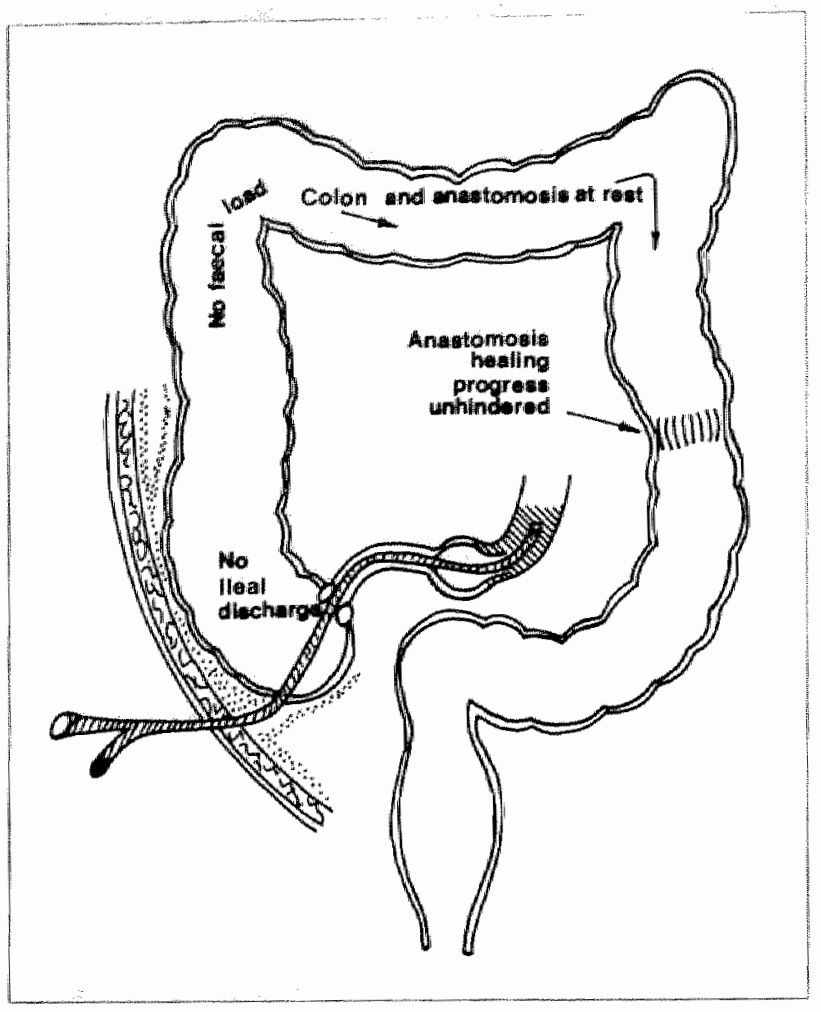

Fig. 13: Transcaecal ileat diversion (from Simpson and Srivastava [2].

\section{The rectal tube}

In non-obstructing lesions of the colon in emergency surgery (tumours, perforation, massive colonic bleeding) or with ill-prepared non-obstructing lesions of the colon in elective surgery, the whole colon can be irrigated with the aid of the newly developed rectal tube [fig. 9].

The non-sterile tube is introduced before the beginning of the operation and before placing the sterile towels. The balloon of the tube is insufflated with $50 \mathrm{ml}$ air or water. It totally occludes the anus, preventing any perianal spillage of faecal contents during irrigation [fig. 10]. The inner diameter of the tube $(21 \mathrm{~mm}$ ) facilitates the passage of gross faecal material without any hindrance. The distance between the balloon and the proximal opening of the tube is very short, preventing retention of faecal material. A plastic bag is fixed distatly at the site of sillicone rings in the tube, thus stopping the bag slipping off.

Instiblation of cancericidal fluid (to kill exfoliated cancer cells in the lumen of the colon and to prevent anastomotic recurrence) and testing of the anastomosis with instillation of methylene blue or $1 \%$ povidone iodine are made feasible by the inbuilt irrigation canal in the tube [fig. 11 l].

If necessary, the whole rectum can be cleaned using the irrigation canal. For this purpose an infusion system containing $1 \%$ povidone iodine is connected to the irrigation canal and a clamp placed distally on the rectal tube. If the rectum is filled with povidone iodine (in case of cleansing during operation faecal masses are broken with the finger by massaging the rectum), the clamp is loosened and faecal material led via the plastic bag to a bucket. This procedure can be repeated until the rectum is totally clean [fig. 12]. 
The rectal tube can be used with the patient either in a supine or in a Lloyd-Davies position. If the patient is in a supine position, after introduction of the rectal tube this is led between the two blades of the urological table and will come out undemeath, where it can be easily handled by the circulating nurse. The surgeon will have no hindrance from its presence during the operation.

\section{Late modifications}

\section{Acute colon decontamination}

A method of intraoperative colon decontamination was studied experimentally and introduced into the hospital.

Irrigation of the colon with $1 \%$ povidone iodine (Betadine $R$ ), was shown to decrease the aerobic and anaerobic bacterial flora including both $E$. coli and B. fragilis within 20 minutes (Chapter 9 ).

This method was easily applicable to the intraoperative colon irrigation procedure. Alter a clear effluent had been achieved, the colon was irrigated with one litre of $1 \%$ povidone iodine saline. This was made by mixing $100 \mathrm{ml}$ of $10 \%$ povidone iodine with one litre of physiological saline from which $100 \mathrm{ml}$ had been removed.

Careful surveillance of the patients receiving the acute colonic decontamination was undertaken, with special concern for the effects on the thyroid and on the bacterial counts at the anastomotic site, both before and after the povidone iodine irrigation. The preliminary results in the first group of patients were very promising .

\section{Transcaecal ileal diversion}

As shown in the clinical study using the intraoperative colon irrigation, only in two cases was a diverting colostomy used. In these cases the surgeon wanted to protecl the anastomoses because of technical problems encountered during the operation.

An ingenious modification to "protect" the anastomosis has been reported by Simpson and Srivastava [2], and this can easily be incorporated in the intraoperative colon irrigation procedure in the following way:

After intraoperative colon irrigation, the tumour is resected and a primary anastomosis performed. If the anastomosis has to be protected, then the irrigation needle is removed. Appendicectomy is performed and a purse-string suture placed around the base of the appendix site. If appendicectomy had been performed previously, then a small incision is made in the caecal wall after placing a purse-string suture around the site of the incision.

A 22 or 24 French gauge Foley type inflatable catheter is negotiated via this lumen (appendix base or caecostomy incision) for a distance of at least $15 \mathrm{~cm}$ beyond the ileocaecal junction. This tube has been previously brought in through an incision in the anterior abdominal wall in the right iliac fossa, as with the tube caecostomy.

The patency of the lumen and the competence of the balloon of the catheter being checked beforehand, the balloon is inflated inside the terminal ileum just sufficiently to occlude the lumen of the ileum without causing ischaemia or undue pressure on the ileal wall.

The purse-string suture around the catheter in the caecal wall is then tightened. A second 
purse-string suture around the catheter is made and the caecotomy site sutured to the lateral wall of the peritoneum so as to make a leakproof seal between the caecum and anterior wall [fig. 13] as described with the tube caecostomy procedure. The tube is kept patent in the same way as the tube caecostomy. The patient is allowed only a liquid diet until removal of the catheter, which is done after confirmation of the integrity of the anastomosis (around the loth day) by gastrographin enema.

\section{References}

\section{Dudley HA, Radcliffe AG, McGeehan D.}

Intraoperative irrigation of the colon to pemit primary anastomosis.

Bir J Surg 1980;67:80-1.

\section{Simpson A, Srivastava VK.}

Temporary transcaccal ileal diversion in prevention of anastomotic leak in planned colonic surgery (an allernative to proximal colostomy).

Br J Surg 1975;74:243-5. 


\section{Part III}

\section{Experimental study}




\section{Chapter 7}

\section{Experiments on the efficacy of antibiotics used in induced intra-abdominal sepsis and their predictive value in colorectal surgery}

\section{Introduction}

Intra-abdominal infections after colorectal surgery involve a complex microflora of both aerobic and anaerobic bacteria [1] from endogenous colonic microorganisms contaminating the adjacent tissue [2]. Prophylactic administration of antibiotics effective against aerobic and anaerobic bacteria is therefore the nule.

In clinical studies reporting the value of different antibiotic regimens as prophylaxis in colonectal surgery, the use of control groups receiving no antibiotics is accepted as being unethical [3].

Consequently the intergroup differences conceming postoperative septic complications are small and large numbers of patients are required for statistically significant conclusions to be drawn [4].

After such a trial had been finished (see chapter 4), questions arose about the need for an experimental model to test the predictibility of these antibiotics.

Experimental infection in animal models offers an alternative for the testing of antimicrobial agents and has the advantage of allowing evaluation under controlled conditions. Furthemore, the study of untreated controls for the understanding of the pathological events that are associated with intra-abdominal contanination and subsequent unfection is made feasible.

Several animal models for postoperative sepsis, peritonitis and abcess formation have been used for studying the efficacy of prophylactic antibiotics [1,5-7].

After a survey of the literature and a pilot study, a model of intra-abdominal sepsis closely approximating to the disease in humans (as described by Lahnborg et al. [8]) has been used to evaluate, in a similar way, the efficacy of the antibiotics which were studied in the elinical trial. Three new antibiotics whose use has been suggested in colorectal surgery were also tested.

The aim of this study was to evaluate the predictive value of such an experimental model in selection or rejection of antibiotics, prior to their application in longlasting trials in colorectal surgery. 


\section{Materials and methods}

\section{Animals}

Male SPF-Brown Norway rats weighing 200-300 grams were obtained from the Centralised Experimental Animal Facilities of the State University of Limburg. All animals were specified pathogen free and housed in groups of 4 per cage and fed with beef food (table 1). Water was given ad libitum.

Table 1: Composition of beef food given to the animals in these experiments in order to change their colonic flora.

neat meal ( $78 \%$ protein; $13 \%$ fat )

blood meal ( $88 \%$ protein )

soluble meat extract ( $88 \%$ protein )

animal fat

vitamin; minerals, etc.
$56.0 \%$

$4.0 \%$

$3.0 \%$

$24.1 \%$

$12.9 \%$

According to this model all rats were given beef food starting 2 weeks before surgery and this was continued until the autopsy. By feeding the animals with meat instead of the rat chow diet, the intestinal flora was similar to that found in humans.

\section{Operative procedure}

Each rat was fasted for 24 hours before the surgical procedures and then anesthetized with ether. Clean but not sterile instruments were used.

The rats were shaved and a midline incision was made. A $2 \mathrm{~cm}$ segment of ileum $5 \mathrm{~cm}$ from the ileocaecal junction was isolated on its vascular pedicle, which was interrupted with a single VicrylR ligature [fig. la]. To prevent unnecessary blood loss, the arcade of the ileum was ligated at the proximal and distal resection sites without inferfering with the circulation of the anastomosis.

The intestine was then divided at each end of the two segments and intestinal continuity was re-established by knotting one layer everted end-to-end anastomosis of the two ends of the ileum with 6-0 VicrylR.

The defect in the mesentery was closed with two or three interrupted 6-0 Vicryl $\left.\right|^{R}$ sutures [fig. [b]. The anastomosis was checked for leakage and patency before the intestine and devascularised segment of the ileum were returned to the abdominal cavity.

The abdominal wall was closed in two layers. The entire operation lasted 10-15 minutes. 

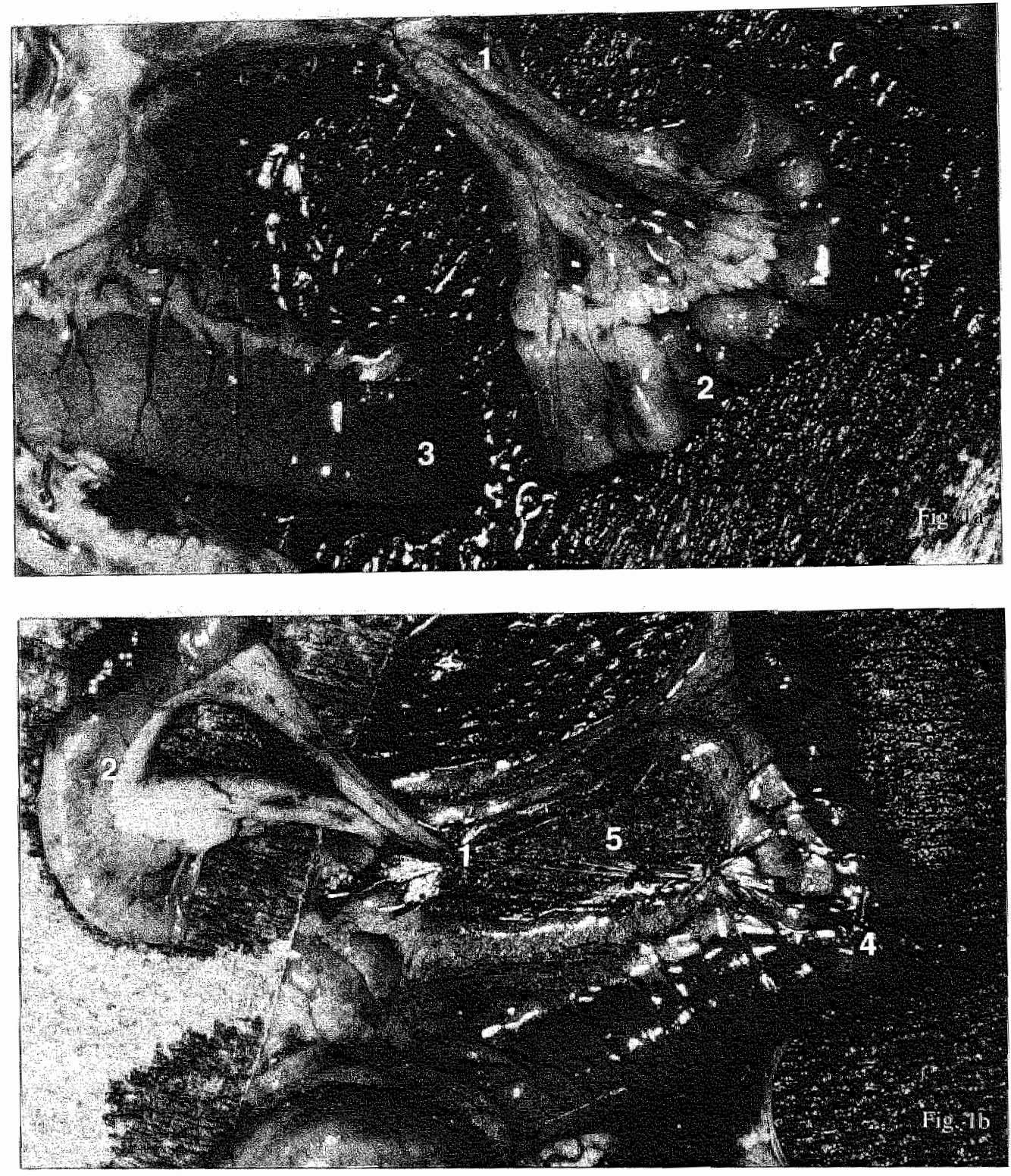

Figs. la and Tb: Operative technique for creation of intra-abdominal sepsis in this study.

$1=$ ligane arownd the vessels to the isolated ileal segment.

$2=$ devasularised ileal segment which gradually became necrotic and subseguenty served as the source of infection.

$3=$ resected ileal ends to be anastomosed.

$4=$ the conrmwity is restored by anastomosing the resected ileal ends with $6-0 \mathrm{Vicry}$.

$5=$ mesentery clased to preven internat herniation of the bowel. 


\section{Antibiotics}

Six groups, each consisting of 12 animals, were formed non-selectively and each antibiotic was tested in a separate group.

Neomycin ( 1 gram/litre) and metronidazole (0.5 gram/litre) were given orally in 3 doses at 8 hourly intervals via a nasogastric tube 3 days before operation and continued for one day post operatively. Each dose contained. $10 \mathrm{mg}$ neomycin and $5 \mathrm{mg}$ metronidazole.

The other antibiotics were given intravenously before the abdominal incision was made. Eight and sixteen hours postoperatively the same dose was administered subcutaneously. The control group received $3 \mathrm{ml}$ of $0.9 \%$ sterile saline administered as mentioned above. The parenteral antibiotics given (per dose) were:

oxytetracycline

tobramycin

amoxycillin-clavulanate

ticarcillin-clavulanate

imipenem

\author{
$1.5 \mathrm{mg}$. \\ $5 \mathrm{mg}$. \\ $100 / 20 \mathrm{mg}$. \\ $150 / 60 \mathrm{mg}$. \\ $10 \mathrm{mg}$.
}

\section{Collection and processing of specimens from intra-abdominal exudate}

Specimens taken with dry cotton-tipped sterile swabs and placed in Stuart medium were transported to the laboratory as soon as possible. All specimens were streaked on two blood agar plates and ten selective media. All manipulations of the anaerobic bacteria were carried out in an anaerobic glove box. The aerobic agar plates were incubated for 24 hours and aerobic plates for 48 hours at $37^{\circ} \mathrm{C}$. The plates were then examined and different colony types isolated in pure culture and identified according to generally accepted microbiological methods.

\section{Evaluation of the results}

The following parameters were used for the evaluation of the efficacy of the antibiotics: mortality rate; time of death; number of abcesses; the presence of adhesions, peritonitis. Autopsy and bacteriological cultures from the abdomen were performed in all animals. The surviving animals (those not dying due to sepsis) were sacrificed 14 days after operation. 


\section{Results}

\section{Control group [fig. 2]}

Within one day $8 / 12(67 \%)$ rats died and all were dead within three days. All these animals showed typical signs of peritonitis and abcesses when they were autopsied. A polymicrobial flora mainly consisting of $E$. coli; Proteus mirabilis; Streptococcus faecalis; Bacteroides fragilis and Clostridium perfingens was recovered from the peritoneal exudate. All rats showed advanced interintestinal adhesions.

\section{Neomycin-metronidazole}

No rats in this group died of sepsis. One rat died 7 days after operation and autopsy showed an ileus due to anastomotic stenosis. No aerobic or anaerobic bacteria could be cultured from the abdomen at autopsy 14 days after survival. Hardly any adhesions were present.

\section{Tobramycin-metronidazole}

No animals died in the first 6 days but one died on the 7 th day and two on the 8 th due to sepsis. E. coli, P. mirabilis and Strept. faecalis were recovered from the peritoneal exudate One rat died on the 13th day and ileus due to invagination of the anastomosis into the caecum was found at autopsy. No abcesses were found in these animals. Moderate adhesion formation was noted in the surviving animals.

\section{Tetracycline}

Within one day ten out of the 12 rats $(83.3 \%)$ died. A mixed microflora with a predominance of $E$. coll, P. mirabils and B. fragilis was found. The two surviving rats showed no abcesses at antopsy but gross intra-abdominal adhesion formation was found.

\section{Amoxycillin-clavulanate(Augmentin R)}

No rats died. At autopsy insignificant adhesion formation was found and no abcesses were noted. Cultures of the abdominal cavity revealed no bacteria.

\section{Imipenem}

One of the animals died on the 4th day. Examination revealed an anastomotic dehiscence with abcess formation in the immediate vicinity of the anastomosis. Polymicrobial intestinal flora was cultured from this abcess. 


\section{Ticarcillin-clavulanate (TimentinR)}

One animal died three days after operation. The surviving animals showed no significant adhesion formation and no abcesses were found at autopsy.

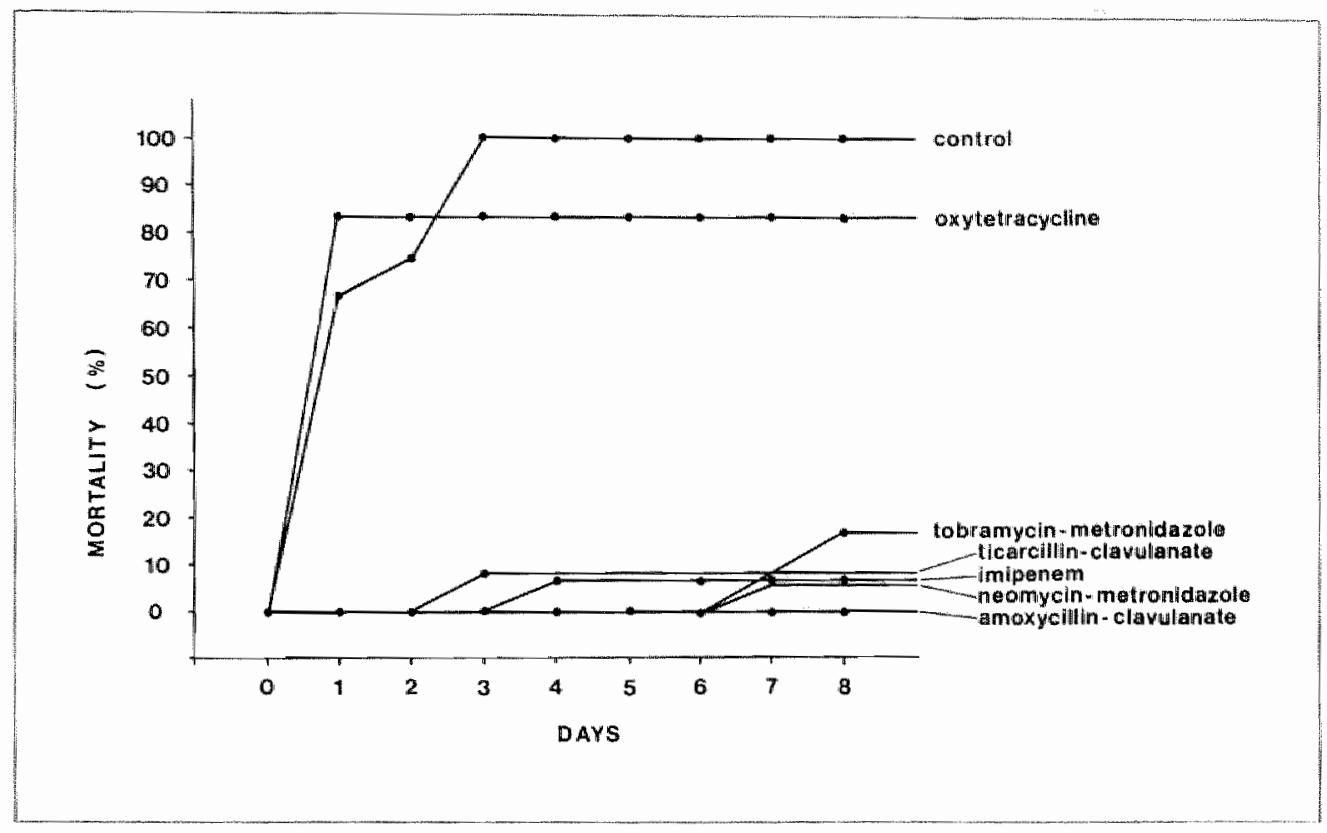

Fig. 2: Mortality rates in the rats in which no antibiotic prophylaxis has been given (control) and in those receiving the antibiotics indicated. 


\section{Discussion}

In onder to simulate the development of clinical conditions of intra-abdominal sepsis, a reproducible model [8] has been used. This model permits the study of both microbiological aspects and the healing of anastomoses. One important surgical aspect is the involvement of the anastomosis for the development of intra-abdominal infection.

Feeding the animals with meat instead of rat chow diet causes the intestinal flora to resemble that in humans [9].

In pilot studies bacterial counts before and after beef food were performed. If the colonic bacteria in the sigmoid of rats with normal food is compared with that of humans, it is noticed that both are comparable except that the total numbers of aerobic (not the $B$. fragilis) and Clostridium species are significantly less present in these rats $(p<0.05$ independent t-test). These two species did increased after beef food. As a consequence, both floras (which were already comparable to a great degree before the beef food diet) became then fully comparable after this diet (table 2).

Nevertheless, if this infection model of progressive necrosis of the devascularised ileum was performed in rats without beef food, no mortality occurned. Our hypothesis is that through this unbalanced diet the general resistance of the rat decreases and enhancement of virulence of the colonic bacteria occurs. The mortality in the model used could not be explained by an increase in colonic flora counts alone. It is however useful as an experimental model for simulating intra-abdominal sepsis and approximating to the bacterial flora in the human colon.

Table 2: Colonic flora before and after beef food in 6 rats per group compared with the colonic flora in 6 humans (log 10 microorganisms/ml faces) and their standard deviations.

Colonic flora

Rats

Humans

without beef food

with beef food

\begin{tabular}{|c|c|c|c|}
\hline total aerobic & $7.98+0.20$ & $8.32+0.46$ & $7.49+1.07$ \\
\hline E. coli & $7.16+0.49^{n}$ & $8.01+0.37^{n}$ & $7.01+1.14$ \\
\hline Enterococcussp & $6.98+0.37$ & $7.36+0.21$ & $5.02+2.30$ \\
\hline Iotal anacrobic & $9.89+0.19 \mathrm{kAn}$ & $10.33+0.26 \mathrm{MA}$ & $10.67+0.39$ \\
\hline $\begin{array}{l}\text { B. fragilis } \\
\text { Clostridiam sp. }\end{array}$ & $8.59+0.56 \&$ & $9.41+0.40 \&$ & $9.06+0.45$ \\
\hline Clostridium sp. & $4.96+0.92 * *$ & $6.52+0.46 \#$ & $5.33+0.70 *$ \\
\hline
\end{tabular}

Symbols indicate a statistical significance of at least $p<00.5$ 
The administration of antibiotics in this study simulates the use of antibiotic prophylaxis in human colorectal surgery. In pilot studies, longer use of antibiotic did not result in a significant decrease in the mortality rate. Only reduced adhesion formation was noticed after 10 days administration of antibiotics. That is why the 24 hours antibiotic regimens seened justified for studying their efficacy against aerobic and anaerobic bacteria in the experimental trial.

Oxytetracycline was used in the past for its alleged broad-spectrum effect against aerobic and anaerobic bacteria. In this experiment it failed to prevent mortality due to sepsis by these organisms. Although none of the animals, cagemates or progenitors had ever been treated with tetracychines, most of the bacteria cultured appeared to be tetracycline resistant. The ineffectiveness of tetracycline for controlling aerobic and anaerobic septic complications has also been demonstrated in a clinical trial (Chapter 4).

Neomycin/metronidazole administration in this experiment yielded excellent results and none of the animals died of sepsis. This result is fully comparable to the clinical frial results using these agents.

Augmentin $^{R}$, Timentin $\mathrm{R}$ and imipenem were shown to be equal and highly effective antibiotics against aerobic and anaerobic bacteria as claimed. Their use as proplyylaxis of therapy in colorectal surgery trials seems justified according to these experimental results. Adhesion formation in this study proved to be directly proportional to the efficacy of antibiotics in controlling sepsis. The better the antibiotic worked, the lesser the degree of adhesion formation. This may indicate that bacterial infection plays an important role in the development of adhesions and that effective antibiotics may inhibit the development of adhesions.

\section{Conclusions}

- The model of Lahnborg et al. simulating intra-abdominal sepsis is suggested in studies for predicting the effectiveness of any antibiotics to be used in colorectal surgery.

Exclusion or selection of antibiotics seems possible using this model.

- The mortality in this experimental model could not be explained by the increased count of colonic bacteria in animals given beef food.

The unbalanced diet resulting in a decreased general resistance is probably the most important factor causing the deaths in this septic model.

- Oral administration of neomycin and metronidazole appeared to be very effective in preventing mortality and adhesion formation. The same results were accomplished using parenteral Augmentin ${ }^{R}$, Timentin ${ }^{R}$ or imipenem.

- Antibiotics effective against the major colonic bacteria seemed to decrease the extent of intra-abdominal adhesion formation. 


\section{References}

\section{Nichols RL.}

Intra-abdominal sepsis: characterization and treatment.

J Infect Dis 1977; 135:554-7.

2. Playforth MII, Smith GMR, Evans M, Pollock AV.

Antimicrobial bowel preparation. Oral, parenteral, or both?

Dis Colon Rectum 1988:31:90-3.

3. Baum ML, Anish DS, Chalmers TC, Sacks H S, Smith H Jr, Fagerstrom RM.

A survey of clinical trials of antibiotic prophylaxis in colon surgery:

evidence against further use of no-treatment controls.

N Engl J Med 1981:305:795-9.

\section{Evans M, Pollock AV.}

The inadequacy of published random control trials of antibacterial prophylaxis in colorectal surgery.

Dis Colon Rectum 1987;30:743-6.

\section{Weinstein WM, Onderdonk AB, Bartlett JG, Louie TJ, Gorbach SL.} Antimicrobial therapy of experimental intra-abdominal sepsis.

J Infect Dis 1975;132:282-6.

6. Onderdonk AB, Weinstein WM, Sullivan NM, Bartlett JG, Gorbach SL.

Experimental intra-abdominal abcess in rats: quantitative bacteriology

of infected animals.

Infect Inmun 1974;10:1256-9.

\section{Bartlett JG, Louie TJ, Gorbach SL, Onderdonk AB.}

Therapeutic efficacy of 29 antimicrobial regimens in experimental intra-abdominal sepsis.

Rev Infect Dis 1981:3:535-42.

\section{Lahnborg $\mathrm{G}$, Hedstroem KG, Nord CF.}

Efficacy of different antibiotics in the treatment of experimentally induced intra-abdominat sepsis.

J Antmicrob Chemother 1982;10:497-504.

\section{Nichols RL, Smith JW, Fossedal EN, Condon RE.}

Efticacy of parenteral antibiotics in the treatment of experimentally induced intra-abdominal sepsis.

Rev Infect Dis 1979;1:302-12. 


\section{Chapter 8}

\section{The influence of antibiotics on colonic anastomosis in rats: evaluation by bursting pressure measurement}

\section{Introduction}

From the earliest days of surgery, colonic anastomotic leakage has been the source of considerable morbidity and mortality and various factors are now known to influence the healling of colonic anastomoses [1-3]. Although technical failure may occur, there are a number of factors to be considered inchuding malnutrition [4], protein depletion [5], trauma $[6]$, blood loss [7] and metabolic impaiment [8].

Similarly, there are known to be a number of local factors which may lead to distuption of an anastomosis: sepsis [9], faecal loading [10], foreign bodies [11] and ischaemia [12].

In experimental studies [13] it has been demonstrated that disruption of an anastomosis occurs by spillage of bacteria during the performance of the anastomosis and not afterwards. Experiments performed in an attempt to find factors minimizing the postoperative septic complications has provided evidence that antibiotics could favourably modify the healing of an anastomosis $[14,15]$.

The aim of this study was to investigate the influence of antibiotics on the healing of colonic anastomoses in the absence and presence of faeces or infection.

The questions posed were:

1. Does optimal bowel preparation (including antibiotics) result in better healling of colon anastomoses?

2. Could antibiotics prevent the impaired healing of an anastomosis in the presence of infection? This was assumed to be the most important question which had to be answered.

3. What is the influence of antibiotics on perianastomotic adhesion formation?

The phenomenon of adhesion formation after bowel anastomosis in an intra-abdominal septic model was reported in a previous study (Chapter 7).

In the following study we wished to record the presence of adhesions conforming 10 a specific protocol and to study the influence of antibiotics on them. The bursting pressure of the left colon containing the anastomosis was used as a parameter for healing. 


\section{Materials and methods}

\section{Animals}

Specific pathogen-free Brown Norway rats that weighed approximately 200 to 300 grams were obtained from the Centralised Animal Facilities of the State University of Limburg.

\section{Housing}

On delivery the animals were numbered and assigned at random to one of the experimental groups. Rats were housed in stainless wire cages, 4 per cage and acclimatised to the laboratory conditions (temp. $22^{\circ} \mathrm{C}$ and a 14 hours day/ 10 hours night cycle) for 2 weeks before the beginning of the experiments.

\section{Diet}

All rats received beef food beginning 2 weeks before surgery, and were maintained on the same diet throughout the experiments. Rats are known to be rellatively resistant to infections and to have an ability to heal their intestine that is well beyond that of humans. Even peritonitis does not carry the same hazards in rats as it does in many humans.

\section{Antibiotics}

Amoxycillin-clavulanate (Augmentin ${ }^{R}$ ) containing $100 / 20 \mathrm{mg}$ per dose was administered intravenously before the laparotomy was made. Eight and sixteen hours postoperatively this dose was repeated subcutaneously. Augmentin ${ }^{R}$ has proved to be an effective agent against aerobic and anaerobic colonic bacteria in an experimental intra-abdominal septic model (Chapter 7).

\section{Infected anastomoses}

In order to study the influence of antibiotics on an anastomosis infected with a specific bacterium, non-monotilamentous (woven) Vicryl $l^{R}$-0 was incubated for 24 hours in a bottle containing a fresh culture of $E$. coli. This infected Vicryl ${ }^{\mathrm{R}}$ was used to perform the anastomoses in groups 4 and 5 .

\section{Bowel preparation}

At the beginning of this study whole gut irrigation (and, later, intraoperative colon irrigation) was used as a bowel preparation to achieve a clean colon before the creation of the anastomosis in the groups in which this was required. 


\section{Whole gut irrigation (WGI)}

The rats were fasted for 24 hours, weighed and anesthetised with ether. When the animal was well anaesthetised, a cannula was inserted via the oesophagus until it reached just into the stomach [16]. The animal was then fixed on to a plate with a built-in heating system maintained at $34^{\circ} \mathrm{C}$. The skin of the cervical area was shaved and disinfected with $1 \%$ povidone iodine before making a longitudinal incision of about $2 \mathrm{~cm}$ along the trachea. The oesophagus was presented by blunt dissection, after which a tourniquet was placed around it to fix the cannula inside. This proved to be necessary to prevent aspiration of the gastric contents during the infusion of the irrigation fluid. After the wound had been covered with gauze soaked in a sterile $0.9 \%$ solution of saline, the WGI began. Starting gently with 0.5 $\mathrm{ml}$ per minute irrigation was increased gradually to a steady state level of $4 \mathrm{ml}$ per minute. The irrigation fluid was preheated to $34^{\circ} \mathrm{C}$ to prevent substantial loss of heat by the animal during the procedure. The irrigation fluid contained $6.00 \mathrm{~g} \mathrm{NaCl}, 0.75 \mathrm{~g} \mathrm{KCl}$ and $2.94 \mathrm{~g}$ $\mathrm{NaHCO}_{3}$ per litre sterile water; the $\mathrm{pH}$ was 8.3 . At the end of the procedure the tourmiquet was removed, the wound was sutured with biodegrable material and the rat was placed in warm surroundings for reconvalescence. All rats were irrigated until the effluent was totally clear.

\section{Intraoperative colon irrigation (ICI)}

Because of the problems (see discussion) encountered with whole gut irrigation, a new method of rapid colonic cleansing (Chapter 3 ) was used in groups 4 and 5. Comparison of WGI and ICI concerning their influence on the healing of colonic anastomoses was made in pilot studies in which no difference at all in bursting pressure was noted between the two methods.

\section{Study groups}

Five groups containing 24 rats each were formed at random. Group 1 (control group) received no bowel preparation and no antibiotics. In group 2 WGI was used as bowel preparation; no antibiotics were administered. All rats in group 3 underwent WGI and received antibiotics as well. In group 4 intraoperative colon irrigation was performed as bowel preparation but previously infected Vicry $\mathbb{R}^{\mathrm{R}}$ was used to perform the anastomosis and no antibiotics were given. In group 5 infected Vicryl ${ }^{\mathbb{R}}$ was used, but antibiotics were given too.

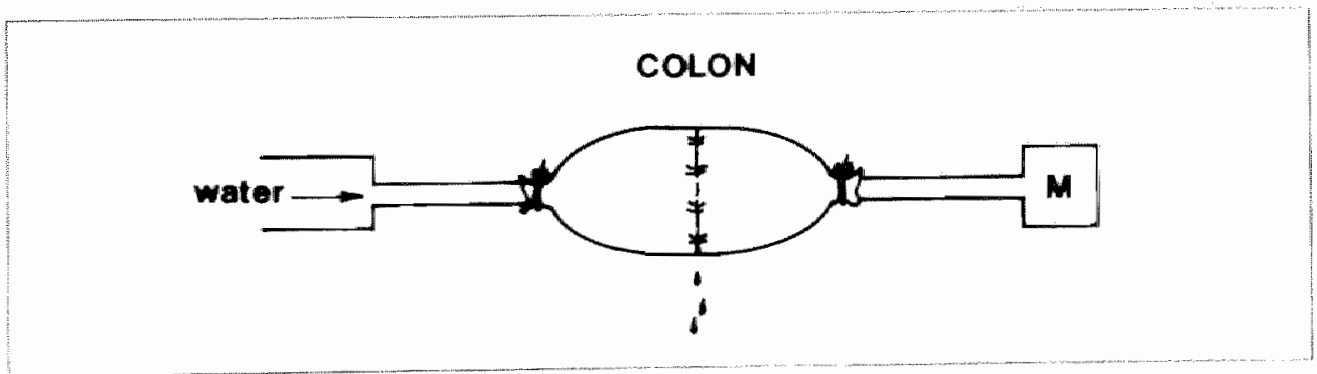

Fig. 1: Principle of the technique of measurement of the bursting pressure in the colon containing the anastomosis. 

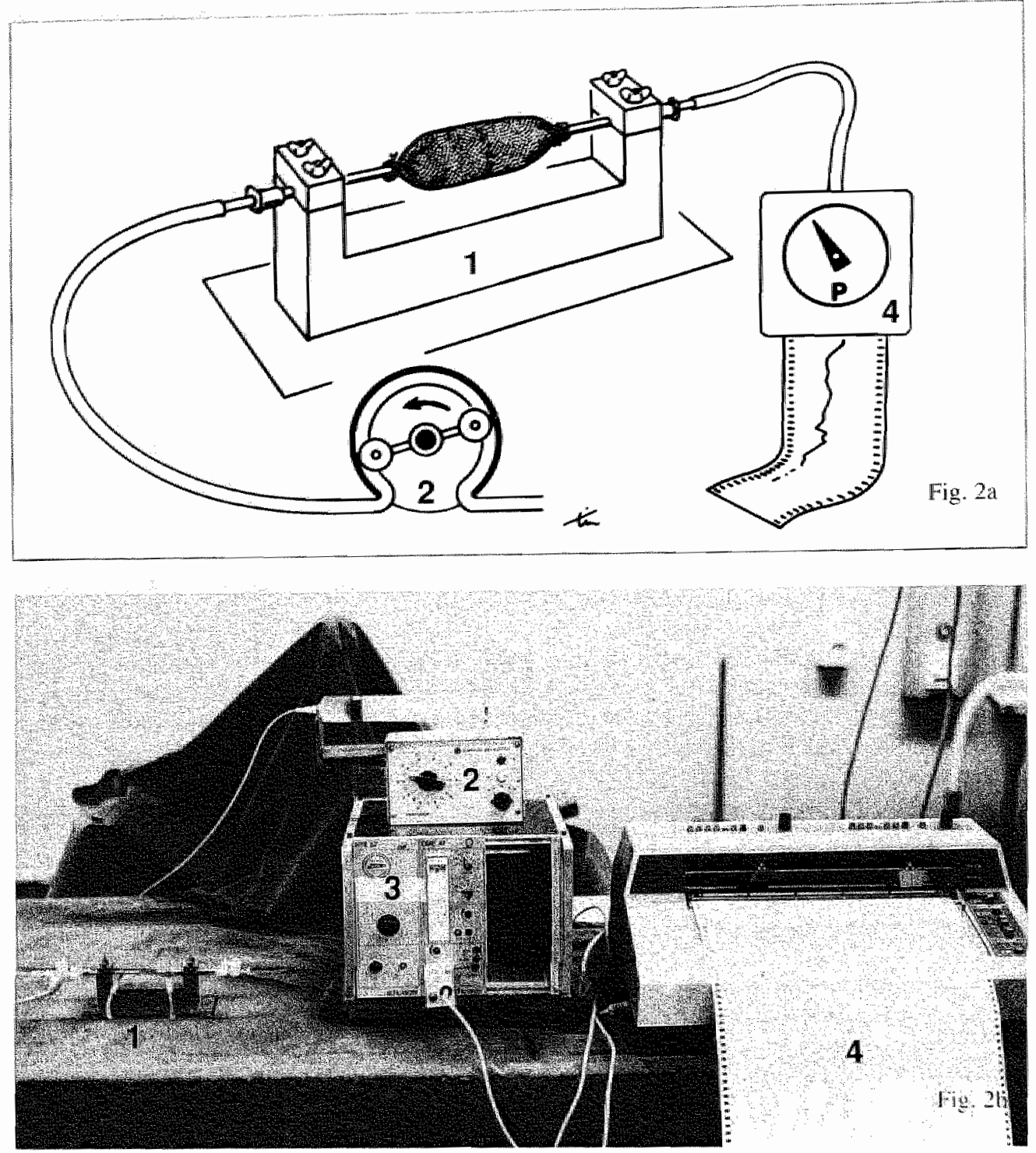

Fig. 2 and b: Apparams and practical set up for measuenents of bursting pressure. $I=$ apparatus constructed by the Physological Laboratory of the State University of Leiden.

$2=$ infusion pump, which infused water at a desired rate.

$3=$ pressure transduces:

$4=$ writer. 


\section{Bursting pressure (BP)}

The principles of the technique of measurement of bursting pressure are illustrated in fig.l. The technique is used mainly for the measurement of the mechanical strength of anastomoses in the gastrointestinal tract: the anastomosis is tested in a standard length of intestine by inflation with water or air until leakage through the bowel wall starts to occur: the intraluminal pressure is recorded at the moment of rupture.

For measuring the bursting pressure of the colonic anastomosis in this study an apparatus constructed by the Physiological Laboratory of the State University of Leiden [8] was used. with permission of Prof. dr A. Zwaveling.

The $5 \mathrm{~cm}$ part of the colon with the anastomosis in the middle was removed, any pellets of faeces were carefully milked out of each segment and the colon was fixed on two hollow needles. One needle was connected to an infusion pump, which infused water at a desired rate. The other needle was connected to a pressure transducer which was, in turn, connected to a writer that reported the pressure graphically. Before the infusion pump was switched on, the whole system was filled with water and calibrated [fig. 2a, b]. With the pump switched on, water was infused at a standard rate. The pressure in the system (and colon) was raised steadily until leakage occurred through the anastomosis or the bowel wall. This was recorded graphically [fig. 3 ].

Bursting pressure was defined as the pressure at which water leaks first appeared or complete rupture of the anastomosis occurred. Measurements were made on the 3rd and 7th days postoperatively and the bursting wall tension was calculated from the product of bursting pressure and the radius of the intestine at the point of rupture, according to the Law of La Place, as reported by Nelsen and Anders [17].

Student's test was used in the statistical analysis of the results of the bursting pressure measurements, as described by Fisher [18].

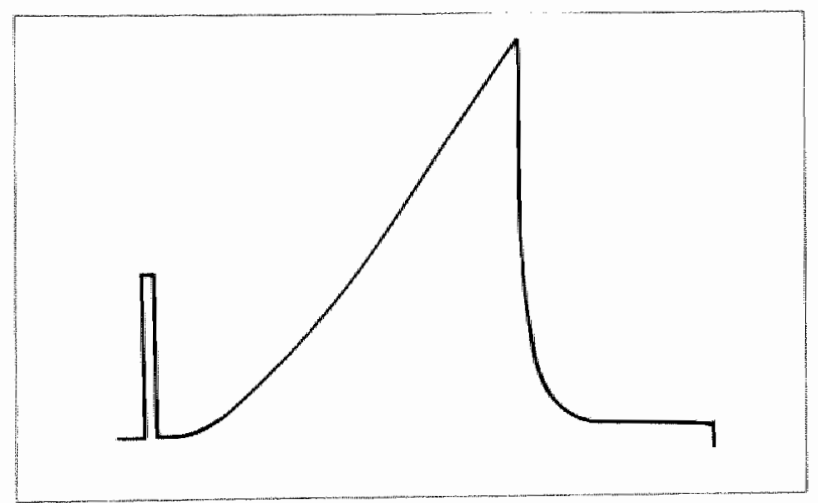

Fig. 3: Erample of graphical illastration of the bursting pressure neasurement (gauge $=100 \mathrm{~mm} \mathrm{Hg})$. After a slow increase a sharp drop in pressare is noticed as the colon starts leaking.

\section{The operation}

All operations were performed immediately after the bowel preparation under ether anaesthesia. Clean but not sterile instruments were used. After shaving, a $4 \mathrm{~cm}$ long midl ine abdominal incision was made. The colon was divided with scissors $3 \mathrm{~cm}$ above the 


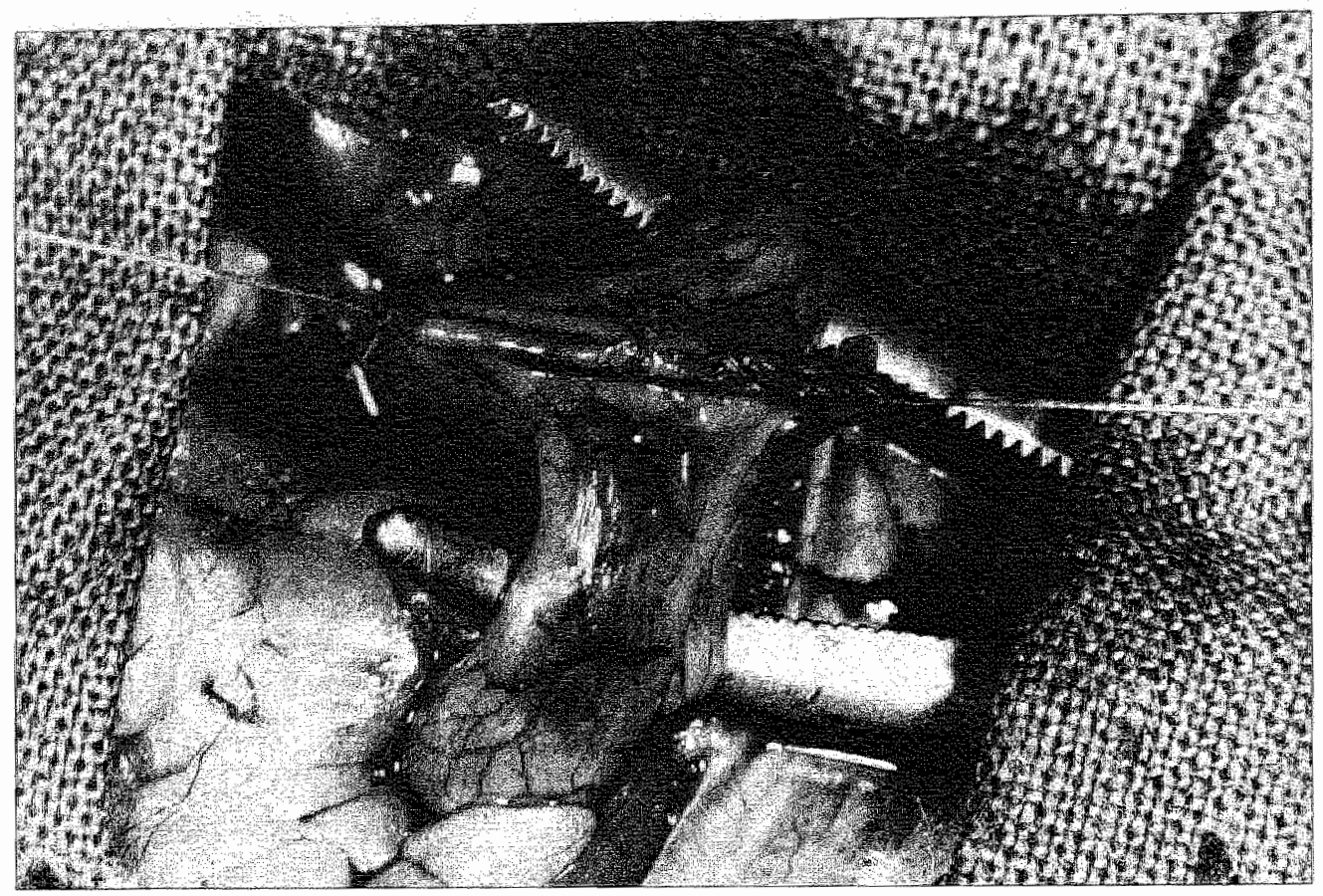

Fig. 4: Performance of the anastomosis in the colon using 5-0 Vicry interrupted everting sutures.

peritoneal reflection. Care was taken not to disturb the cinculation of the anastomosis. The colon was anastomosed with one layer of approximately 8 interrupted everting sutures through all layers using VicrylR 5-0 |fig. 4. The abdomen was closed in one layer with a 30 0 running Mersilene ${ }^{R}$ suturo.

\section{Autopsy procedure}

Half of the rats in each group were killed with an overdose of ether on the 3rd day and the rest of the animals were sacrificed on the 7 th day. The abdomen was opened and adhesions present were noted as reported by Mol \19!:

$\mathrm{O}=$ no adhesions, or a thin fibrin coat at the mesenteric side of the anastonosis

$+\quad=$ adhesion or stringing to the mesentery involving no more than $1 / 4$ of the anastomotic surface

$+4 \quad=$ adhesions involving not more than half the surrounding of the anastomosis $\mid$ fig. $5 \mid$

$+++=$ more than a half of the surface of the anastomosis is surounded by aldhesions

$++++=$ massive, often circular adhesions around the anastomosis and in the vicinity involving other organs (walling-off by adjacent healthy tissue) [fig. 6]. 

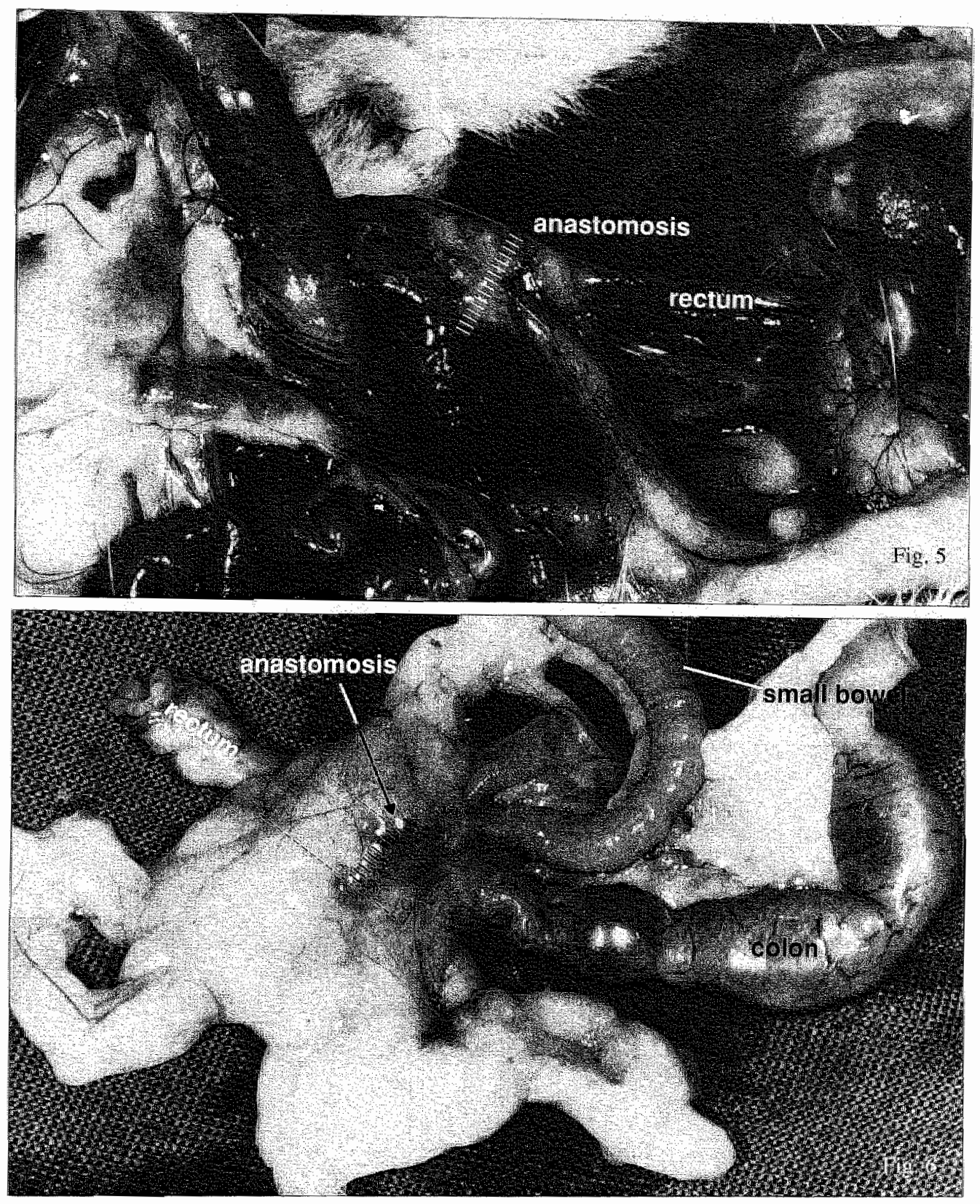

Fig. 5: Example of grade ++ perianastomotic adheston formation.

Fig. 6: Example of grade ++++ perianastomatic adhesion formation. 
The whole colon was removed; adhesions were cut from their surroundings, attempts being made not to exert any traction on the anastomosis.

Fve cm of the left colon with the anastomosis in the middle were excised for measurements. The bursting pressure was measured in an adjacent piece of the remaining colon of equal length, in order to quantify the bursting pressure in the normal colon of that group [figs. 7 a and b].
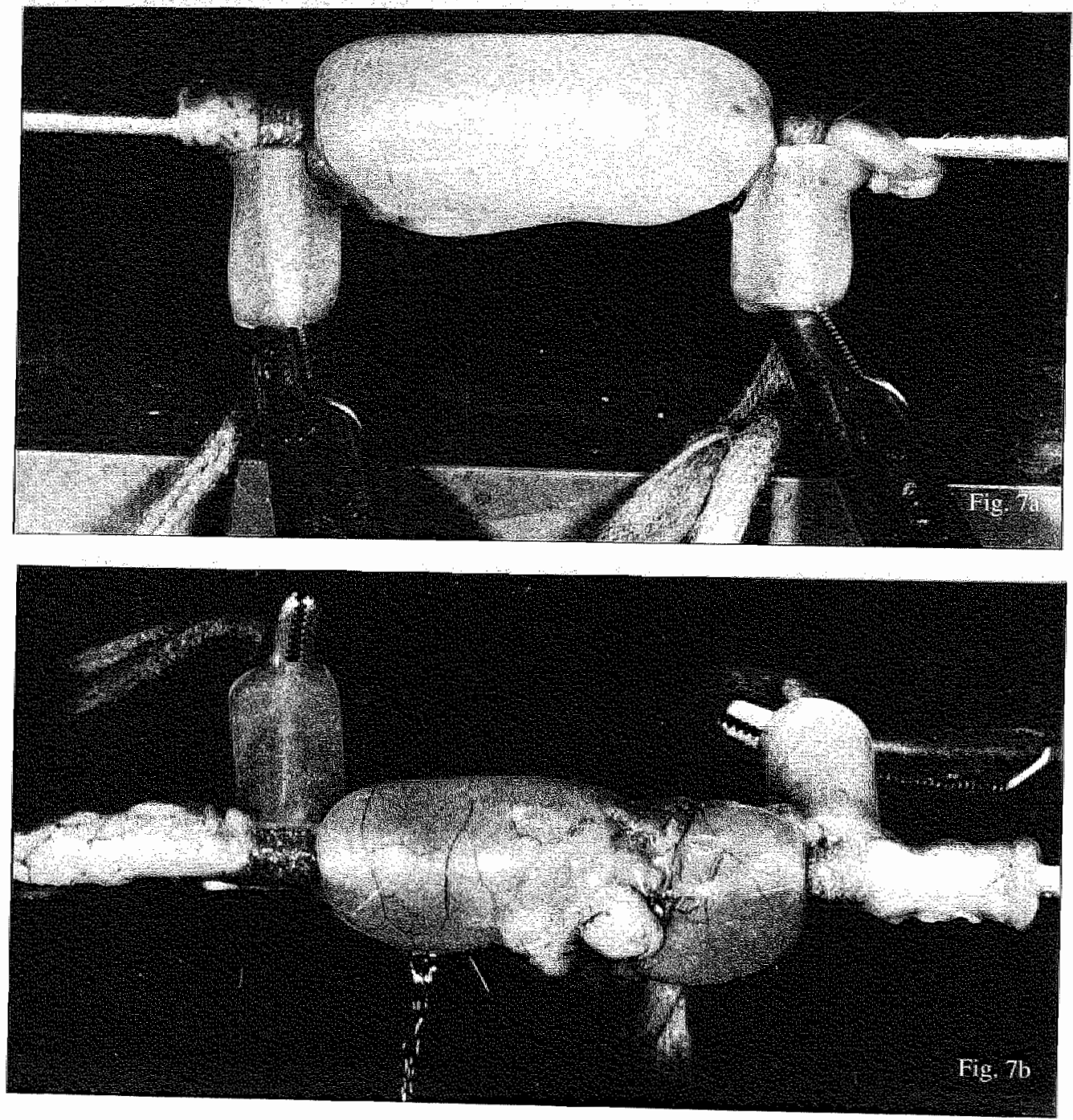

Fig. 7 a and b: Bursing pressure measurement in the nownal colon (a) and in the colon combining the anastomosis (b). which in this case shows teakage near to, but not in, the
anastomosis. 


\section{Results}

The results of bursting pressure measurements of the colonic anasfomoses are shown in table 1.

Nine rats in group 4 (infected anastomosis without antibiotics) died within 3 days due to sepsis from the infected VicrylR. The bursting pressure was measured on the 3rd day in 7 animals in this group and on the 7th day in 8 of them.

Bursting pressure measurements on the 3rd day in all groups appeared to be very disappointing. In 8 of the 53 surviving rats the anastomosis broke down during attempts to remove the whole colon carefully. In 12 animals (divided over the several groups) no pressure at all could be recorded. In the remaining 23 animals only very low bursting pressures, varying from 5 to $30 \mathrm{~mm} \mathrm{Hg}$, were noted.

On this day the anastomoses appeared to have virtually no strength and therefore these results have not been analysed statistically.

An increase of the bursting pressure on the 7 th day was seen in the groups given antibionics but this was not statistically significantly different from the other groups (independent $\mathrm{t}$-test). No differences at all were registered in bursting pressure of the normal colon in the various groups, as expected (table 1).

Table 1: Bursting pressure in normal colon of the rats and in the colon conaining the anastomosis on the 7 th day.

Groups

Bursting pressure ( $\mathrm{mm} \mathbf{H g}$ )

no. normal colon anastomosis

$\begin{array}{llll}1 \text { (WGI-/ANT-) } & 12 & 321.7 \pm 49.4 & 197.5 \pm 10.4 \\ 2(\text { WGI+/ANT-) } & 12 & 295.8 \pm 50.8 & 189.2 \pm 13.9 \\ 3(\mathrm{ICI}+/ \mathrm{ANT}+) & 12 & 347.5 \pm 22.3 & 205 \pm 19.5 \\ 4(\mathrm{ICI}+/ \mathrm{ANT}-/ \mathrm{INF}+) & 8(4 t) & 291.7 \pm 47.5 & 189.2 \pm 12.4 \\ 5(\mathrm{ICI}+/ \mathrm{ANT}+/ / \mathrm{NF}+) & 12 & 294.2 \pm 36 & 197.8 \pm 7.9\end{array}$

$\mathrm{WGI}+1-$ with $(+)$ or without $(-)$ whole gut irrigation

$\mathrm{ICI}+/-=$ with $(+)$ or without - ) intraoperative colon irrigation

$\mathrm{ANT}+1-=$ with $(+)$ or without $(-)$ antibiotics

INF $+/=$ with $(+)$ or without $(-)$ infected anastomosis 
The most striking difference on the 7 th day was the gross appearance of the anastomoses. Animals receiving no antibiotics in which an infected anastomosis had been used (group 4) showed the presence of numerous adhesions. The whole anastomosis was mostly sealed off by omentum, small bowel, bladder and seminal vesicles [fig. 6], whilst in rats receiving antibiotics (groups 3 and 4 ) the anastomoses were surrounded by only a few friable adhesions, or none at all $(\mathrm{p}<0.05)$.

Table 2: The degree of perianastomotic adhesion formation (grades 0 to ++++ ) in the differem groups 7 days after resection and anastomosis of the left colon.

\begin{tabular}{|c|c|c|c|c|c|c|c|}
\hline \multirow{2}{*}{\multicolumn{2}{|c|}{ Groups }} & \multirow[t]{2}{*}{ no. } & \multicolumn{4}{|c|}{ grade } & \multirow[b]{2}{*}{++++} \\
\hline & & & 0 & + & ++ & +++ & \\
\hline 1 & (WGI-/ANT-) & 12 & & 3 & 7 & 2 & \\
\hline 2 & (WGI+/ANT-) & 12 & 1 & 6 & 4 & 1 & \\
\hline 3 & $(\mathrm{ICl}+/ \mathrm{ANT}+)$ & 12 & 9 & 3 & & & \\
\hline 4 & $\left(\mathrm{ICl}+/ \mathrm{ANT}-/ / \mathrm{NF}_{+}\right)$ & $8(4 t)$ & & & & 1 & 7 \\
\hline 5 & $\left(\mathrm{ICI}+/ \mathrm{ANT}+/ \mathrm{INF}^{+}+\right)$ & 12 & 7 & 4 & 1 & & \\
\hline
\end{tabular}

$0 \quad=$ no adhesions at atl

$++++=$ massive perianastomotic adhesions

Statistical analysis of the groups ( Kruskal-Wallis tests):

1 vs 2 = not significant

I $\vee \mathrm{s} 3=\mathrm{p}<0.05$

4 vs $5=p<0.05$

2 vs $4=p<0.05$ 


\section{Discussion}

In the beginning of this study, WGI was used as the method to obtain a colon totally free of faeces, as described by Ruys et al. [16]. The procedure lasted for about $2-3$ hours using 200-300 ml fluid. As a method of colonic cleansing (in order to perform an anastomosis in a faeces-free colon) this method appeared to be time-consuming and during our learning phase several rats died after whole gut irrigation.

Confronted with this problem, the intraoperative colon irrigation (ICD) was introduced in animals. This appeared to be a very easy method to use, giving a totally empty colon within 10 minutes. No rats at all died while this method was being used and it is proposed as the method of choice. It can also be used in experiments with other animals in which a tolally clear colon is required, for example, for anastomotic studies.

Several parameters for studying anastomotic healing have been suggested including:
a. clinical leakage $[20,21]$
b. radiological leakage [22]
c. bursting pressure [23-26]
d. tensile strength $[27,28]$
e. collagen content [29-35]
f. microvascular study [36]
g. (scanning electron) microscopy $[37,38]$
h. oxygen tension [39].

Encouraged by the findings of others $[8,40,41,42]$ it was decided to use the bursting pressure as a parameter of anastomotic healing, but it did not appear to be useful due to the problems with perianastomotic adhesion formation.

Bursting pressure measurements on the third day proved to be useless as a parameter of anastomotic healing. As observed by others $[22,43]$ the strength of an anastomosis during the first three days depends wholly upon the strength of the suture material and the tissue holding it.

In pilot studies more than half of the rwelve colonic specimens ruptured through the normal colon rather than through the anastomosis during bursting pressure tests on the 10th postoperative day. Only in a few rats was this the case on the 7th day. Leakage on this day occurred mostly at the anastomosis and not in the normal colon. Therefore this day was chosen for measuring bursting pressure.

It has been suggested by this study that in case of small leakages (or if anastomotic healing is impaired for some reason), any decrease in bursting pressure could then be completely masked by adhesion formation. The more the anastomotic healing is impaired, the more adhesion formation or sealing off by healthy tissue will occur.

This hypothesis has been supported by histological studies [44] and it agrees with the findings of other workers $[45,46]$.

In an early phase of healing as shown by Jiborn [47] lower bursting pressures will be noticed in the cases of increased adhesions and uneventful healing, but if the bursting pressure is measured on a later date ( 7 th day) no differences between impaired and 
unimpared anastomotic healing will be noticed, due to the firmness of organized adhesions. This is in conformity with our findings.

If the colon is pulted out of the abdomen for bursting pressure measurements, even the most careful removal of these adhesions from the anastomosis will damage it. The bursting pressure will not then reveal the real strength caused by the healing of the anastomosis but will be a product of healing and iatrogenic artefacts.

On the other hand, if the adhesions are left attached to the anastomosis as in this study (by cutting the anastomosis carefully from the surrounding tissues without using any raction) then the bursting pressure will not really ilustrate the anastomotic healing but will be influenced by the degree of "sealing off".

Bursting pressure differences reported by studies $[8,25]$ comparing anastomotic healing in different groups of animals (eg. numour-bearing and non tumour-bearing animals from irradiated and non-irradiated rats) are probably not as much influenced by adhesion formation as is the case with fully comparable groups (concerning nutritional, immunological and metabolic states) in which an infection model is used as in this study.

After this study was finished, a silastic cylinder sheet $2 \mathrm{~cm}$ in length and $1 \mathrm{~cm}$ in diameter was constructed, cul open along one side in the length and fixed loosely around the anastomosis in order to study healing without interference with adhesions.

Surprisingly $[48$, the sheet was recognized as a foreign body, dramatically incorporated into the surrounding tissue, and, in a few cases, had perforated into the colonic lumen by the 7 th day.

The hazardous effect of wrapping anastomoses with sheets (in dogs) have been reported by Ravitch 149,50$]$. In his study, all anastomoses which had been wrapped with polyethylene sheets broke down. The most reasonable explanation appeared to be that in anastomoses not prepared by antibiotics there was considerable bacterial contamination of the anastomotic area. If the anastomoses were then isolated from the protective defences of the peritoneum by interposed foreign material, infection around the suture line would result, progressing to necrosis, leakage and fatal peritonitis.

Other writers have reported [13] that perforated sheets may prevent this complication. Reports of omentectomy or regimens of promethazine and dexamethasone [51] for inhibition of adhesion formation should be tested for their merits. on condition that they do not disturb anastomotic healing.

Although it is suggested by this study that antibiotics in combination with an optinal bowel preparation did not result in any improvement in anastomotic healing. this conclusion is not correct due to the degree of adhesion fomation and its interference with the bursting pressure in impaired anastomotic healing. Safe methods for isolating the anastomosis from adhesions should be investigated before the performance of bursting pressure studies to evaluate anastomotic healing in infection models. Articles on this subject using bursting pressure as "the" parameter of anastomotic healing - and totally ignoring the problems of adhesion formation - should be read with scepticism. 


\section{Conclusions}

- The bursting pressure is unreliable as a parameter for the stidy of anastomotic healing in fully comparable groups of rats using an infection model, unless the (infected) anastomosis can be studied in complete and safe isolation from adhesion formation.

- Intraoperative colon irrigation as a procedure for obtaining a totally clean colon for studies in experimental animals appears to be rapid, highly effective, safe, easy to use and thus preferable to whole gut irrigation.

- The only effect of antibiotics in this study was the significant inhibition of adhesion formation, especially in animals where an infected anastomosis was used. 


\section{References}

1. Hunt TK, Hawley PR.

Surgical judgment and colonic anastomoses.

Dis Colon Rectum 1969;12:167-71.

2. Irvin TT, Goligher JC.

Aetiology of disruption of intestinal anastomoses.

Br J Surg 1973;60:461 -4.

\section{Hawley $\mathrm{PR}$.}

Catuses and prevention of colonic anastomotic breakdown.

Dis Colon Rectum 1973;16:272 7 .

\section{Irvin TT, Hunt TK.}

Effect of malnutrition on colonic healing.

Ann Surg 1974;180:765-72.

\section{Daly „JM, Vars HM, Dudrick SJ.}

Effects of protein depletion on strength of collonic anastomoses.

Surg Gynecol Obstet 1972;134:15-21.

\section{Zederfeldt B.}

Studies on wound healing and trauma.

Acta Chir Scand 1957; Suppl 224.

7. Whitaker BL, Dixon RA, Greatorex G.

Anastomotic failure in relation to blood transfusion and blood loss.

Proc R Soc Med 1970;63:751.

\section{Graal PW de.}

The influence of tumorgrow th on woundhealing. An experimental study in the rat [Thesis]. Leiden: State University of Leiden, 1981. 99 pp.

\section{Clarke IS, Condon RE, Bartllett JG, Gorbach SL, Nichols RL, Ochi S.}

Preoperative oral antibiotics teduce septic complications of colon operations: results of prospective, randomized, double-blind clinical study.

Ann Surg 1977; 186:251-9.

\section{Smith SR, Conolly JC, Gilmore O.J.}

The effect of faecal loading on colonic anastomotic healing.

Br J Surg 1983:70:49-50.

\section{Mellish RWP.}

Inverting and everting sutures for bowel anastomosis.

J Pediatr Surg 1966:1:260-4 
12. Schrock TR, Deveney CW, Dunphy JE.

Factors contributing to leakage of colonic anastomoses.

Ann Surg 1973;177:513-8.

13. Rusca JA, Bornside GH, Cohn I Jr.

Everting versus inverting gastrointestinal anastomoses: Bacterial leakage and anastomotic disruption.

Ann Surg 1969;169:727-35.

14. Cohen SR, Cornell CN, Collins MH, Sell JE, Blanc WA, Altman RP.

Healing of ischemic colonic anastomoses in the rat: role of antbiotic preparation.

Surgery $1985 ; 97: 443-6$.

15. LeVeen HH, Wapnick S, Falk G, et al.

Effects of prophylactic antibiotics on colonic healing.

Am J Surg 1976;131:47-53.

16. Ruys GJ, Waay D van der.

Experimental whole gut irrigation in the rat.

Scand J Infect Dis 1986; 18: 469-75.

17. Nelsen TS, Anders C.J.

Dynamic aspects of small intestinal rupture with special consideration of anastomotic strength.

Arch Surg 1966;93:309-14.

18. Fisher RA.

Statistical methods for research workers.

London: Oliver \& Boyd, 1958.

19. Mol PCM.

Over de darmnaad; een historische inleiding en een experimenteel onderzoek naar de bruikbaarheid wan de everterende naad [Thesis].

Nijmegen: Catholic University of Nijmegen, 1970. $118 \mathrm{pp}$.

20. Fielding LP, Stewart-Brown S, Blesovsky L, Kearney G.

Anastomotic integrity after operations for large-bowel cancer; a multicentre study.

Br Med J 1980;281:411-4.

21. Matheson NA, Valerio D.

Large-bowel surgery, 1979: self assessment.

Br Med J 1980;281:719-21.

\section{Goligher JC, Graham NG, De Dombal FT.}

Anastomotic dehiscence after anterior resection of rectum and sigmoid.

Br J Surg 1970;57:109-18.

23. Cronin K, Jackson DS, Dunphy JE.

Changing bursting strength and collagen content of the healing colon.

Surg Gynecol Obstet 1968;126:747-53. 


\section{Young HL, Wheeler MH.}

Effect of intravenous aprotinin (Trasylol) on the healing of experimental colonic anastomoses in the rabbit.

Eun Surg Res 1983;15:18-23.

\section{Winsey K, Simon R, , Levenson SM, Seifter E, Demetriou AA.}

Effect of supplemental vitamin $A$ on colon anastomotic healing in rats given preoperative irradiation.

Am J Surg 1987; 153:153-6.

26. Hawley PR, Faulk WP, Hunt TK, Dunphy JE.

Collagenase activity in the gastrointestinal tract.

Br J Surg 1970;57:896-900.

\section{Ehrlich HP, Hunt TK.}

Effects of cortisone and vitamin $A$ on wound healing.

Ann Surg 1968;167:324-8.

\section{Jonsson K, Jiborn H, Zederfeldt B.}

Breaking strength of small intestinal anastomoses.

Am J Surg 1983;145:800-3.

\section{Cronin K, Jackson DS, Dunphy JE.}

Specific activity of hydroxyproline-iritium in the healing colon.

Surg Gynecol Obstet 1968;126:1061-5.

30. Irvin TT.

Collagen metabolism in infected colonic anastomoses.

Surg Gynecol Obstet 1976;143:220-4.

\section{Jiborn H, Ahonen J, Zederfeldt B.}

Healing of experimental colonic anastomoses. III. Collagen metabolism in the colon after left colon resection.

Am J Surg 1980;139:398-405.

\section{Stromberg BV, Klein L.}

Collagen formation during the healing of colonic anastomoses.

Dis Colon Rectum 1982:25:301-4.

\section{Blomquist P, Jiborn H, Zederfeldt B.}

Effect of diverting colostomy on collagen metabolism in the colonic wall. Studies in the rat. Am J Surg 1985; 149:330-3.

\section{Young HL, Wheeler MH.}

Collagenase inhibition in the healing colon.

J R Soc Med 1983;76:32-6. 


\section{Tornqvist A, Blomquist $\mathbf{P}$, Ahonen J, Jiborn $\mathbf{H}$, Zederfeldt B.}

The effect of stenosis on collagen metabolism in the colonic wall. Studies in the rat. Acta Chir Scand 1988; 154:389-93.

\section{Houdart R, Lavergne A, Valleur $\mathbf{P}$, Villet $\mathbf{R}$, Hautefeuille $\mathbf{P}$.}

Vascular evolution of single-layer end-on colonic anastomosis. A microangiographic study of 180 anastomoses in the rat from two to 180 days.

Dis Colon Rectum 1985;28:475-80.

\section{Greven AT.}

Mechanische darmanastomosen. Een experimenteel chirurgisch onderzoek [Thesis].

Amsterdam: University of Amsterdam, 1988.94 pp.

38. Tonietti G, Cimmino PT, Ranucci A, Baggella G, Accinni L.*

Electron microscopy study of the effects of amikacin and cefadroxil on colonic anastomoses in rabbits.

Int $\mathbb{J}$ Tissue React $1982 ; 4: 253-60$.

\section{Shandall A, Lowndes R, Young HL.}

Colonic anastomotic healing and oxygen tension.

Br J Surg 1985;72:606-9.

\section{Haukipuro KA, Hulkko OA, Alavaikko MJ, Laitinen ST.}

Sutureless Colon Anastomosis with fibrin glue in the rat.

Dis Collon Rectum 1988;31:601-4.

\section{Irvin TT, Edwards JP.}

Comparison of single-layer inverting, two-layer inverting, and everting anastomoses in the rabbit colon.

Br J Surg 1973:60:453-5.

\section{Scheinin TM, Viljanto J.}

Bursting pressure of healing gastrointestinal wounds in the rat.

Ann Med Exp Fenn 1966;44:49-51.

\section{Dunphy JE, Udupa KN.}

Chemical and histochemical sequences in the normal healing of wounds.

N Engl J Med 1955;253:847-9.

\section{Ormiston MC.}

A study of rat intestinal wound healing in the presence of radiation injury.

Br J Surg 1985:72:56-8.

\section{McLach AD, Olsson LS, Pitt DF.}

Anterior anastomosis of the rectosigmoid colon: an experimental study.

Surgery 1976;80:306-11.

\section{Ellis H.}

The aetiology of post-operative abdominal adhesions: an experimental study.

Br J Surg 1962;50:10-6. 


\section{Jiborn $\mathrm{H}$, Ahonen J, Zederfeldt $\mathrm{B}$.}

Healing of experimental colonic anastomoses. II. Breaking strength of the colon after left colon resection and anastomosis.

Am J Surg 1978:136:595-9.

48. Mellish RWP, Ty TC, Keller DJ.

A study of intestinal healing.

J Pediatr Surg 1968:3:286-91.

\section{Ravitch MM.}

Some considerations on the healing of intestinal anastomoses.

Surg Clin North Am 1969;49:627-35.

\section{Ravitch MM, Brolin R, Kolter J, Yap S.}

Studies in the healing of intestinal anastomoses.

World J Surg 1981;5:627-37.

\section{Kho E, Replogle R, Ravitch MM.}

Studies of intestinal healing. IV. Prevention of adhesions following inverting and everting bowel anastomoses with promethazine and dexamethasone.

Arch Surg 1969;98:764-5. 


\section{Chapter 9}

\section{Acute intraoperative decontamination of the colon: an experimental study}

\section{Introduction}

Colorectal operations are associated with a high incidence of septic conplications [1]. Most infections are endogenous and caused by spillage of intestinal contents at the time of operation [2].

Attempts to reduce this high incidence of infection should therefore be directed to the reduction of faecal mass by evacuation of the colon, decontamination of the bowel [3], by adequate levels of an appropriate antibiotic at the time of bacterial invasion during operation [4] and aneticulous operative technique [5]. This goal has been achieved in elective colorectal surgery either by preoperative whole gut irrigation with neomycin and metronidazole in the irrigation fluid $[6,7]$ or by whole gut irrigation with preoperative intravenous administration of antibiotics.

In emergency colorectal surgery e.g. for diverticulitis, obstructing carcinoma ischaemic bowel disease or trauma, intraoperative irrigation of the colon [8] has been practised. With this procedure the faecal mass in the colon is optimally removed, but it has only a minor effect on the faecal bacteria during operation.

Antimicrobials administered during these emergency operations (mostly obstructing carcinomata) can attain adequate tissue concentration bat due to the lack of lime no reduction of the flora in the lumen of the colon can be expected.

As a consequence, more infection has been noted after these operations compared with elective colorectal surgery, even when patients with an already contaminated abdomen (trauma, perforation) are excluded.

The aim of this study was to find a method for rapid decontamination of the colon which was easily applicable to the intraoperative colon imigation procedure.

Polyvinyl pyrrolidone iodine (povidone iodine, PVP-I) has been shown to be safe and effective broad spectrum bactericidal agent and is known to exert its action rapidly [9-15]. Is use was therefore studied. Secondly, the influence of oxygen on the colon flota was studied. After the intraoperative colon irrigation procedure, some fluid still remains in the colon. In order to prevent spillage during operation most of this fluid is removed by blowing the colon through with $\mathrm{CO}_{2}$ gas which is normally available in the operating room. Instead of blowing through with $\mathrm{CO}_{2}$, oxygen was chosen in these experimenus because of its toxicity to obligately anaerobic bacteria, which are the major constituent of the colonic flora. 
At first, in-vitro studies were performed to test whether a rapid and significant reduction of colonic microorganisms could be achieved with a $1 \%$ povidone iodine solution (a 1:10 dilution of the commercial $10 \%$ concentration). Then the antibacterial effect of povidone iodine and oxygen on the flora in the colonic walls of rats was examined in an in-vivo study.

\section{Materials and methods}

\section{In-vitro studies}

The povidone iodine $10 \%$ stock solution used was: Betadine lot X 870506 (Dagra-Pharma BV, Diemen).

Faeces were obtained from four healthy volunteers and from four rats. The rats were sacrificed for this purpose and faeces was removed from the descending colon and sigmoid.

Data derived from experimental pilot studies showed that after intraoperative colon irrigation a reduction of more than 2 logarithms of the microorganisms in the colon occurred, due to both the removal of the faecal mass and to dilution. In order to obtain a good comparison with the in-vivo study in which the colon irrigation was performed, it was decided to dilute the faeces in the in-vitro study by a factor of 100 .

The influence of metronidazole and neomycin on the faecal flora was examined as a comparison in order to evaluate the speed of reduction of the bacterial flora by these antimicrobials in the irrigation fluid used in the colon lavage procedure.

Three faecal suspensions of $0.5 \mathrm{~g}$ from each volunteer or rat were diluted in pre-reduced anaerobic sterilised diluent $(\mathrm{pH}=7.2)$ so that $45 \mathrm{ml}$ mixture was obtained.

Thereafter, $5 \mathrm{ml}$ saline was added to the $45 \mathrm{ml}$ mixture in the control group, giving a final dilution of $1: 100$.

In the PVP-I group, $5 \mathrm{ml}$ of $10 \%$ PVP-I was added instead, providing a concentration of $1 \%$ PVP-I in the test solution.

In the antimicrobial group, $5 \mathrm{ml}$ of solution containing neomycin (1000 $\mathrm{mg} / \mathrm{l})$ and metronidazole $(500 \mathrm{mg} / \mathrm{l})$ were added instead. The procedure is shown schematically in fig. 1. All suspensions were kept at $37^{\circ} \mathrm{C}$ under anaerobic conditions during the experiments. After thorough mixing, $0.5 \mathrm{ml}$ aliquots of each suspension were processed for subsequent determination of surviving organisms at 10,20,30,60 minutes and 24 hours after injecting the test solution. Within each set $0.5 \mathrm{ml}$ aliquots of the saline control were taken at the same interval to eliminate any effect that the order of processing might have on the bacterial counts. 


\section{Faeces from a volunteer or rat}

Dilntion

$1: 100$ with

Test medium

Test solution

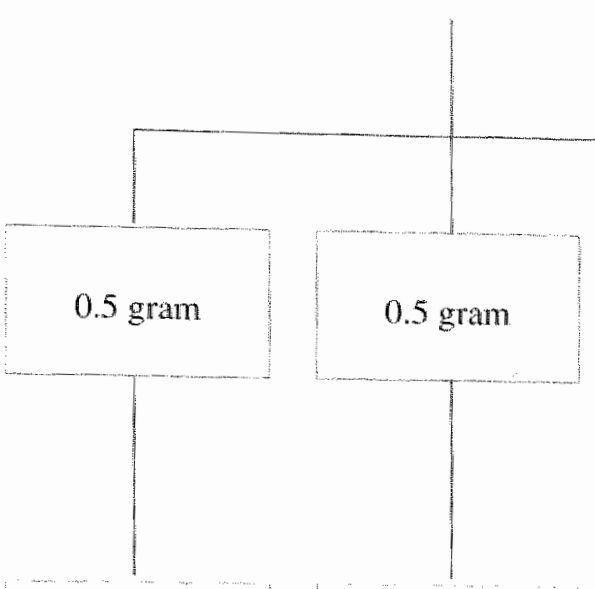

$45 \mathrm{ml}$ saline

$45 \mathrm{ml}$ saline

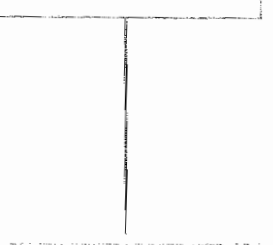

$5 \mathrm{ml}$ saline

$5 \mathrm{ml} \mathrm{PVP}-1,10 \%$

$5 \mathrm{ml}$ neonycin

$50 \mathrm{ml}$ faeces + PVP.J, 1\% and metronidazole

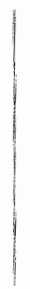

0.5 gram

$45 \mathrm{ml}$ saline

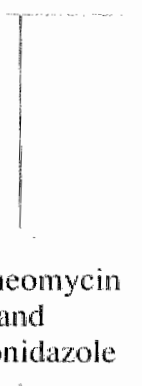

$50 \mathrm{mllacces}+$ neomycin metronidazole

Fig. 1: Schematic illustration of the in-vito experiment. 


\section{In-vivo study}

Specific pathogen free-BN rats, ranging in weight from $300-400$ grams, were obtained from the Centralised Animal Facilities of the State University of Limburg. Preoperatively, all rats had free access to water and irradiated food rat chow (Hope farms, Woerden, The Netherlands). The animals were separated at random into three groups, each of 9 rats. None of the rats had received antibiotics before or during the experiments. All rats underwent an intraoperative colon irrigation with saline.

\section{Technique of the intraoperative colon irrigation}

The rats were anesthetised with ether. After shaving and desinfection of the skin, a distal median laparotomy wals made and only the caecum luxated above skin level. A pursestring suture was made in the caecum and a button-probe with a Luerlock connection introduced. Saline warmed up to $37^{\circ} \mathrm{C}$ was aspirated into a $60 \mathrm{ml}$ syringe. A small vascular clamp was placed on the ileum to prevent reflux of fluid and the colon was irrigated with the saline solution until the effluent was totally clear. In the PVP-I group, this was followed by irrigation of the colon with $60 \mathrm{ml}$ of $1 \%$ PVP-I.

The procedure lasted only 10 minutes and $120-180 \mathrm{~m} \rrbracket$ saline was necessary to achieve a clear effluent. In the oxygen group, after the irrigation, the colon was blown through with $100 \%$ oxygen at $44 \mathrm{~mm} \mathrm{H}_{2} \mathrm{O}$ pressure for 5 minutes. After the irrigation, the button-probe was removed and the caecotomy closed with the purse-string suture (Vicryl ${ }^{R} 2-0$ ). The abdomen was closed in one layer, including skin and peritoneum, with a continuous running suture. Twenty minutes after the irrigation, all rats were sacrificed with an overdose of ether and the abdomen was reopened by cutting the running suture.

A $3 \mathrm{~cm}$ segment of the descending colon was excised, immediately placed in an anaerobic transport bottle and processed within 5 minutes in an anaerobic glovebox for aerobic and anaerobic quantitative cultures.

\section{Bacteriological methods}

The excised descending collon was homogenised and thoroughly mixed with 9 parts prereduced anaerobic saline (PRAS) diluent (salline with $0.05 \%$ cysteine $\mathrm{HCl}$ ) using a turrax mixer. All homogenates in the in-vivo and the in-vitro studies were serially diluted tenfold $\left(10^{10}\right)$ and an aliquot of $0.036 \mathrm{ml}$ of each dilution was spread over the surface of plates using a spiral plater (Spiral System Model B, Lameris, Utrecht, The Netherlands).

The facultative aerobic microflora was quantitated, presumptively identified and grouped by plating the dilution $10^{16}$ on to selective and differential plates. Five per cent sheep blood agar (Oxoid $\mathrm{CN} 55$ ) was used for the total count of facultative aerobes; Levine agar (Oxoid CM 69) for counting coliforms. All plates were incubated for 48 hours at $37^{\circ} \mathrm{C}$ under atmospheric conditions before counting.

For the total obligatory anaerobe counts dilutions $10^{10}$ were inoculated on Wensinck. medium $|16|$. A selective medium containing bile salts and aesculin was used for the quantitation of the Bacteraides fragilis group [17]. All plates for anaerobes were incubated 
in an anaerobic glovebox at $37^{\circ} \mathrm{C}$ in an atmosphere containing $10 \% \mathrm{H}_{2}, 10 \% \mathrm{CO}_{2}$ and $80 \% \mathrm{~N}_{2}$. The plates were counted after 48 hours and after one week. Colony comnts were expressed as the 10 logarithm per gram of colon faeces. Microbiological data were analysed by Student's t-test.

\section{Results}

In-vitro studies

Bacterial counts before and after exposure of the human faeces to PVP-I and neomycin/metronidazole are shown in fig. 2 .

Treatment with $1 \%$ PVP-I resulted within 10 minutes in elimination of all aerobic and anaerobic microorganisms $(p<0.002)$ except for clostridia and the bacilli. The action of PVP-I on spores seemed to be much weaker as has been reported by others [18]. Killing of the clostridia occurred afier longer exposure.

Treatment with neomycin and metronidazole showed only a slow reduction in the anaerobic organisms and no effect at all on the aerobic flora within 60 minutes. The influence of $1 \%$ PVP-I and the antimicrobials on the colonic flora of the rat were the same as on human faeces. Due to the irradiation of the food given preoperatively, to the rats, Bacillas spp. were eliminated and the action of PVP-I on them could not be tested.

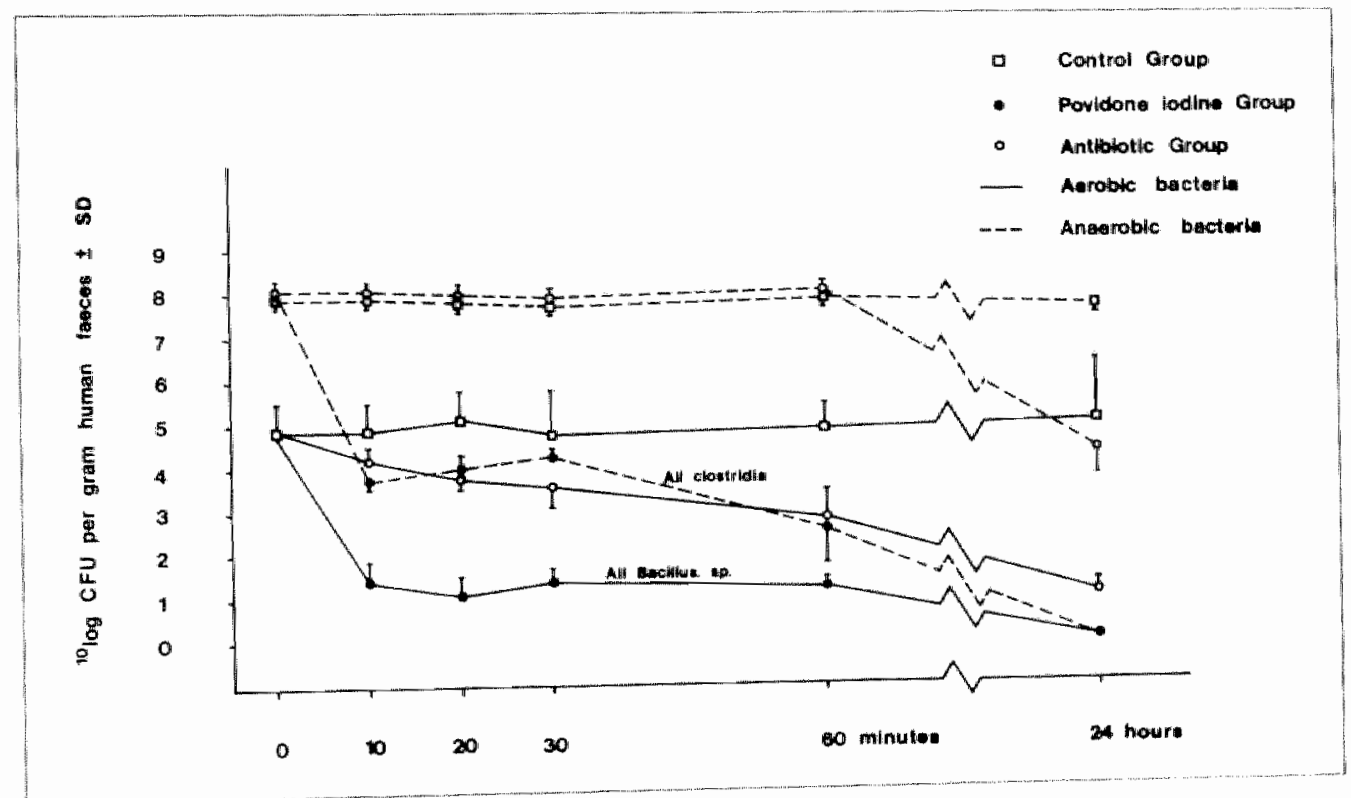

Fig. 2. Mean and standard deviations of the total aerobic and anaerobic coums afier invitro exposure of human faeces to povidone iodine or antibiotics. 


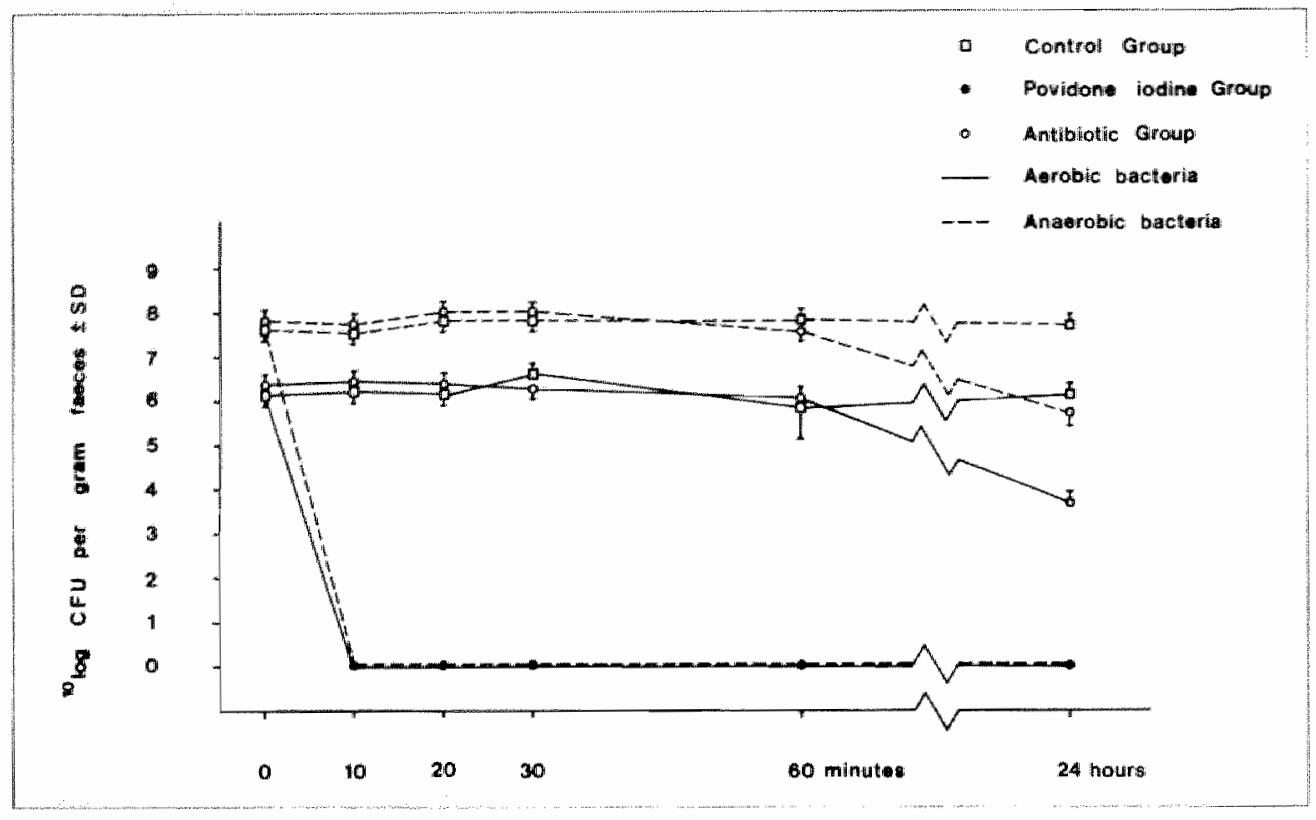

Fig. 3: Mean and standard deviation of the toral aerobic and anaerobic counts after inwive exposure of rat faces to povidone iodine or antibiotics.

\section{In-vivo studies}

The microbiological data are summarised in fig. 2. Separate cultures and counts of $B$. fragilis and $E$. coli were done, in order to study the in-vivo effects of PVP-I and oxygen on these most important pathogens in colorectal surgery. Saline had no effect. Exposure of the colonic flora after the colon irrigation to the PVP-I for 20 minutes in the manner described resulted in a dramatic reduction in the number of $B$. fragills $(\mathrm{p}<0.0001)$. From six of the nine specimens no $B$. fiagilis could be cultured ( $<\log 2)$, (table2).

The influence of PVP-』 on the total aerobic flora (table 1) was more pronounced than on the total anaerobic flora, although both were significantly $(p<0.001)$ reduced compared to the control group. This was also the ease with $E$. coti.

In the group treated with oxygen no reduction in the colon flora was noticed (table 1). 
Table 1: Mean and standard deviations of the toral aerobic anaerobic, E, coll and B. fragilis coumts (log CFU/g colon wall) 20 mimutes after exposure to saline. PVP-I and axyen.

Microorganisms

Saline

PVP-I

Oxygen

total aerobic

$6.00+0.58$

$2.91+0.59 \mathrm{~h}$

$5.93+0.86^{\circ}$

total anaerobic

$7.01+0.50^{d}$

$4.09+0.720$

$6.74+0.72^{1}$

E.coli

$5.57+0.63$

$2.63+0.72^{h}$

$4.89+1.02^{i}$

B. fragilis

$5.82+0.78 \mathrm{i}$

$2.09+0.20^{k}$

$5.61+1.081$

a vs $b: p=0.0001$

a vs $c: p=0.81$

d vse: $p=0.0001$

d vs f: $p=0.37$

g vs h: $p=0.0001$

g vs i: $p=0.11$

j vs $k: p=0.0001$

jvs l: $p=0.65$

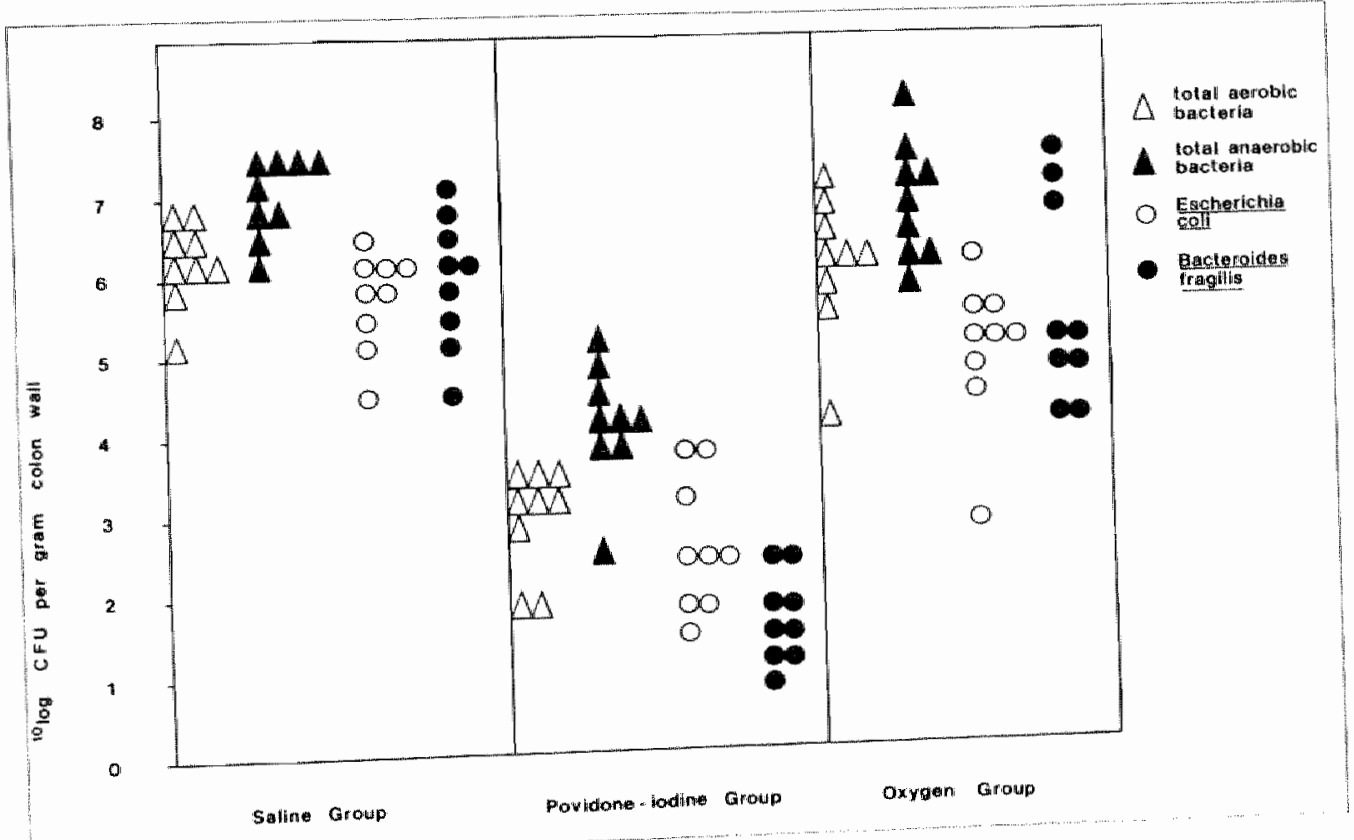

Table 2: Mean total aerobic, anaerobic. E. coli and B. fragilis counts 20 monutes after invive exposure to saline, povidone iodine and oxygen. 


\section{Discussion}

Even high levels of appropriate antibiotics do not effectively prevent wound infection in colorectal surgery when there is massive bacterial contamination from the unprepared intestine [4]. In the present study we have suggested that also in emergency surgery, after an intraoperative irrigation of the colon with 1\% PVP-I, a rapid and significant reduction of the total aerobic and anaerobic bacteria could be brought about, with a profound effect on Bacteroides fragilis which are among the most important anaerobic species.

Oxygen, on the contrary, exerted no effect at all on the bacteria and the expected influence on the anaerobic flora was not realised. Because the obligately anaerobic bacteria are susceptible to oxygen, the idea arose during the in-vivo experiments of using oxygen instead of $\mathrm{CO}_{2}$ as a additional means of reducing the anaerobic flora.

No preliminary in-vitro study with oxygen had been carried out and no probable dangers which oxygen could cause in the operating room had been investigated. If oxygen appeared to work, the safety of its use in this way would have to be studied but due to the results of the in-vivo experiments no such study was necessary.

Complete sterilisation of the colon is not feasible by any of the commonly used methods for bowel preparation in colorectal surgery and was also not achieved with the PVP-I irrigation procedure. It should be noticed that only the colon is irrigated and return of the normal flora (apart from growth of the bacteria present in the colon wal]) will occur due to passage of the small bowel contents as soon as peristalsis starts again.

All aliquots taken from the stock solutions were serially diluted tenfold $(1010)$ before spreading them over the surface of the plates for the aerobic and anaerobic cultures. These dilluted aliquots of PVP-I $(0.0001 \%)$ were previously tested and found not to be inhibitory to any of the challenge organisms. Due to the degree of dilution the iodine was inactivated and therefore neutralisation (for example, with sodium thiosulphate) was not necesary [19].

PVP-I lavage for antegrade whole gut irrigation as preoperative bowel preparation has been used in elective surgery [20]. However, significant bacterial reduction in combination with adequare tissue levels of antibiotic can be reached safely with metronidazole and neomycin in the irrigation flluid during the whole gut irrigation [7] which makes this method superior. There is now little controversy about the use of solutions of PVP-I as abdominal irrigations during surgery. In the literature more benefit $[10,11,21-25]$ than disadvantage $[26-29]$ has been reported with this procedure.

In the present study we used the 1\% PVP-I concentration (1:10 dilution of the $10 \%$ stock solution) because this solution has been used in clinical practice for abdominal irrigation. Secondly, increased antibacterial activity of dilute preparations of povidone iodine solutions has been demonstrated by Berkelman et al [30|. A maximal bactericidal action was noticed between $1 \%$ and $0.01 \%$ PVP-I $(1: 10$ and 1:1000 dilutions of the stock solution). The hypothesis in their article was that with dilution the non-complex-bound iodine increased, and this was responsible for the killing activity.

Gottardi $|31,32|$ and others [33] showed that, starting from a commercially available $10 \%$ solution, the content of non-complex-bound iodine initially increased as the dilution increased. reaching a maximum value at about $0.1 \%$ strength solution (1:100 dilution) and falling again on further dilution. 
With the results of these two studies a good correlation between the microbicidal activity and the content of non-complex-bound iodine $\left(\mathrm{I}_{2}\right)$ could be reproduced.

The concept that the microbicidal activity of PVP.I solutions must be atrributed to the effect af the non-complex-bound iodine is thereby reinforced and nowadays generally accepted $[34,35]$.

The safety and efficacy of bowel irrigation with PVP-I has been demonstrated by animal experiments and also in man, where it has been used as an enema. Also segments of human colon have been treated this way $[13,14,19,36,37]$. However PVP-1 at $5 \%$ or $10 \%$ concentration has been used in nearly all these studies.

Thirdly, dilute solutions of PVP-I (1\%, for example) showed also decreased mucous membrane irritation and decreased toxicity. In their experiment with $10 \% \mathrm{PVP}-\mathrm{I}$ enemas in dogs Orsay et al. [38] noted an excessive mucous discharge and erythema which disappeared when $5 \%$ PVP-I was used.

Irritation tests performed on the conea of rabbits once more demonstrated better tolerance of the more dilute PVP.I solution [35].

Moreover, it has been suggested that the irritation/toxicity of the PVP-I depends on the total iodine concentration (which decreases in diluted PVP-I) and not from the non complexbound iodine (which increases with dilution 351 ).

Generally no bacterial resistance against povidone iodine occurs after repeated use 139,40$]$. Bacterial resistence to PVP-I after 25 years of use as a broad spectrum antiseptic has only been reported in 2 publications $[41,42]$. Pseudononas cepacia, in some case protected by organic or inorganic materials, seemed to be pseudoresistant. PVP.I exerts its bacterial action by oxidation and rapid binding of the non-complex-bound $\mathrm{I}_{2}$ to bacterial proteins $[4,10,43,44]$ and due to this mechanism overgrowth of organisms resistant to antimicrobials is highly improbable.

The influence of $1 \%$ PVP-I on thyroid function is well established $124,45-52\rceil$. Alter abdominal irrigation with PVP-I, an increase in serum iodine has been noted and transient alterations of the T4 and TSH (without any toxic effects) have been found. However, these values return to nomal within a lew weeks in adults.

Neonates, however are more susceptible to PVP-1. After prolonged use in infants with omphalocele, 3 cases of povidone iodire-induced hypothyroidism have been reported to date [53-55]. Although there are no reports in the literature of permament hypothyroidism in infants following the use of iodine-containing antiseptics, their use in noonates is not advocated [56].

PVP-I has been well tolerated in iodine hypersensitive 144. patients, although its use in these patients should not be encouraged.

Experimental investigations have demonstrated that PVP-I did not interfere with anastomotic healing [38] and, on the contrary, antiseptic irrigation of the rat before and after surgery has been shown to produce a significantly lower percentage of cases with colonic dehiscence $[57]$.

An additional benefit of the use of PVP-I in colorectal surgery might be its cylotoxic effect on tumour cells.

Umpleby et al. [58] compared cytotoxic agents used intraluminally to prevent suture line recurrence following resection of the large bowel for cancer. They showed that PVP-I was 
11. Sindelar WF, Mason GR.

Intraperitoneal irrigation with povidone-iodine solution for the prevention of intratabdominal abscesses in the bacterially contaminated abdomen.

Surg Gynecol Obstet 1979:148:409-11.

12. Jones FE, DeCosse JJ, Condon RE.

Evaluation of "instant" preparation of the colon with povidone-iodine.

Ann Surg 1976; 184:74-9.

13. Parker MC, Ashby EC, Nicholls MW, Dowding CH, Brookes JC.

Povidone-iodine bowel irrigation before resection of colorectal carcinoma.

Ann R Coll Surg Engl 1985;67:227-8.

\section{Doerner A, Doehn M.}

Peritoneal and thoracic lavage with PVP-I.

Zurich: IOth international congress of chemotherapy, 1977.

\section{Jones FE, DeCosse JJ, Condon RE.}

Experimental evaluation of "instant" preparation of the colon with powidone-iodine.

Surg Clin North Am 1975;55:1343-8.

\section{Wensinck F, Ruseler-van Embden JGH.}

The intestinal flora of colonization-resistant mice.

J Hyg (Camb) 1971;69:413-21.

\section{Livingston SJ, Kominos SD, Yee RB.}

New medium for selection and presumprive identification of the Bacteroides fragilis group. J Clin Microbiol 1978;7:448-53.

\section{Saggers BA, Stewart GT.}

Polyvinyl-pyrrolidone-iodine: an assessment of antibacterial activity.

J Hyg (Camb) 1964;62:509-18.

\section{Green BL, Litsky W.}

The use of sodium sulphite as a neutralizer for evaluating povidone-iodine preparations.

Heallh Lab Sci 1974;11:188-94.

\section{Gerami S, Kalani BP, Vaezzadeh K.}

Antegrade povidone-iodine (PVD) lavage of gastrointestinal tract for effective preoperative preparation for colorectal surgery.

Am J Proctol Gastroenterol Colon Rectal Surg 1983;34:13-5.

\section{Gilmore OJA, Reid C, Houang ET, Shaw EJ.}

Prophylactic intraperitoneal povidone-iodine in alimentary tract surgery.

Am J Surg 1978: 135:156-9.

22. Flint LM Jr, Beasly DJ, Richardson JD, Polk HC Jr.

Topical povidone-iodine reduces montality from bacterial peritonitis.

J Surg Res 1979:26:280-4. 


\section{Johnson JN, Croton RS, McGlinchey JJ, McLoughlin GA.}

The effect of povidone-iodine irrigation on perineal wound healing following proctectomy for carcinoma.

J Hosp Infect 1985;6 (suppl A):81-6.

\section{Sindelar WF, Brower ST, Merkel AB, Takesue EI.}

Randomised trial of intraperitoneal irrigation with low molecular weight povidone-iodine solution to reduce intra-abdominal infections complications.

J Hosp Infect 1985;6(suppl A):103-14.

\section{Weissenhofer W.}

Effect of betadine solution on bacterial peritonitis. In: The Proceedings of the II World Congress on Antisepsis.

New York: HP Publishing Co. Ine., 1980:72-4.

\section{Kuijpers HC.}

Is prophylactic abdominal irrigation with polyvinylpyrrolidone iodine (PVPI) sate?

Dis Colon Rectum 1985:28:481-3.

\section{Ahrenholz DH, Simmons RL.}

Povidone-iodine in peritonitis. 1. Adverse effects of local instillation in experimental E. coli peritonitis.

J Surg Res 1979;26:458-63.

\section{Lagarde MC, Bolton JS, Cohn I Jr.}

Intraperitoneal povidone-iodine in experimental peritonitis.

Aun Surg 1978; 187:613-9.

29. McAvinchey DJ, McCollum PT, McElearney NG, Mundinger G Jr, Lynch G. Antiseptics in the treatment of bacterial peritonitis in rats.

Br J Surg 1983;70:158-60.

\section{Berkelman RL, Holland BW, Anderson RL.}

Increased bactericidal activity of dilute preparations of povidone-iodine solutions. J Clin Microbiol 1982:15:635-9.

\section{Gottardi W.}

Potentiometrische Bestimmung der Gleichgewichtskonzentrationen an freiem und komplex gebundenen Jod in waessrigen Loesungen von Polyvinylpyrrolidon-Jod (PVP-1).

Z Anal Chem 1983;314:582-5.

\section{Gottardi W.}

Der Gehalt an freiem Jod in wässrigen Lösungen von PVP-1-Jod (Polyvinylpyrrolidon-Jod). Hyg Med 1983;8:203-9.

33. Horn D, Ditter W.

Physikalisch-chemische Grundlagen der mikrobiziden Wirkung wässriger PVP-1-JodLösungen. In: Hierholzer G, Goertz G. PVP-Jod in der operativen Medizin.

Berlin: Springer Verlag, 1984:7-19. 
34. Pinter E, Rackur H, Schubert R.

Die Bedeutung der Galenik fuer die mikrobizide Wirksamkeit von Polyvidon JodLösungen.

Pharm Ind 1983:46:3-8.

\section{Rackur H.}

New aspects of mechanism of action of povidone-iodine.

J Hosp Infect 1985;6(suppl A): 13-23.

\section{Banich FE.}

Intra-operative colonic irrigation with povidone-iodine: an effective method of prevention of wound sepsis.

J Hosp Infect 1985;6(suppl A):216-7.

\section{Gottardi W.}

The influence of the chemical behaviour of iodine on the germicidal action of disinfectant solutions containing todine.

J Hosp Infect 1985;6 (Suppl A): I- II.

\section{Hay JM, Boussougant Y, Roverselli D, Regnard JF, Meyrignac P, Lacaine F.}

The use of povidone-iodine enema as pre-operative preparation for colorectal surgery: bacteriological study.

J Hosp Infect 1985;6(suppl A):115-6.

\section{Orsay CP, Prasad ML, Abcarian H, Kocka FE, Roccaforte P.}

Preoperative antimicrobial preparation of the colon with powidone-iodine enema.

Dis Colon Rectum 1986;29:451-3.

39. Houang ET, Gilmore OJA, Reid C, Shaw EJ.

Absence of bacterial resistance to povidone-iodine.

J Clin Pathol 1976;29:752-5.

40. Gocke DJ, Ponticas $S_{q}$ Pollack W.

In vitro studies of the killing of clinical isolates by povidone-jodine solutions.

J Hosp Infect 1985;6(suppl A):59-66.

41. Berkelman RL, Lewin S, Allen JR, et al.

Pseudobacteremia attributed to contamination of povidone-iodine with Pseudomonas cepicial.

Ann lntern Med 1981:95:32-6.

42. Craven DE, Moody B, Connolly MG, Kollisch NR, Stottmeier KD, McCabe WR. Pseudobacteremia caused by povidone-iodine solution contaminated with Pseudomonas cepacial.

New Engl J Med 1981:305:621-3.

43. Keitel HG.

New clinical implications and therapeutic advances in medical and surgical antisepsis with Betadine microbicides.

Florida: Symposium. 9-10 april 1971. 
44. Shelansky HA, Shelansky MV.

PVP-Iodine: history, toxicity and therapeutic uses.

IIntern Coll Surg 1956:25:727-34.

45. Strife CF, Uhl M, Morris D, Fallon $G$.

Peritoneal absorption of povidone iodine.

Lancet 1977;1:1265.

46. Mummenthaler $H$, Aeberhard $P$. Der Einfluss des intraperitonealen Lavage mit Polyvinglpymolidon-Jod aut den Jodgehalt
des Serums und die Schilddrüsenfunktion.

Hel Chir Acta 1982;49:99-104.

47. Goertz G, Haering $R$, Henckel M, Meinhold H.

Die Schilddrüsenfunktion nach Peritoneallavage mit PVP-Jodlosung bei diffuser Peritonitis.

Zenuralbl Chir 1984;109:319-30.

48. Pyati SP, Ramamurthy RS, Krauss MT, Pildes RS.

Absorption of iodine in the neonate following topical use of povidone iodine.

I Pediatr 1977:91:825-8.

49. Chabrolle JP, Bavoux $F$, Leger AF, et al.

Goitre a l'iode secondaire a l'utilisation d'alcool iode chez le nowveau-ne.

Therapie 1978;33:109-19.

\section{Jackson H.I, Sutherland RM.}

Effect of povidone-iodine on neonatal thyroid function.

Lancet $1981 ; 2: 992$.

51. Lyen KR, Finegold D, Orsini R, Herd JE, Parks JS.

Transient thyroid suppression associated with topically applied povidone-iodine.

Am J Dis Child 1982;136:369-70.

52. Gloebel B, Gloebel H, Andres $\mathrm{C}$.

The risk of hyperthyroidism following an increase in the supply of iodine.

J Hosp Infect $1985 ; 6($ suppl A):20:-4.

53. Cosman BC, Schullinger JN, Bell JJ, Regan JA.

Hypothyroidism caused by topical povidone-iodine in a newborn with omphalocele.

J Pediatr Surg 1988;23:356-8.

54. Wuilloud A, Kehrer BH, Zuppinger KA, et al.

Erworbene Hypothyreose bei einem Neugeborenen durch Anwendung einer fod-haltigen Salbe.

Z Kinderchir 1977;20:181-5.

\section{Tummers RFHM, Krul Ed, Bakker HD.}

Passagère hypothyreoidie ten gevolge van huid desinfectie met jodium bij een pasgeborene met en omfalokèle.

Ned Tijdschr Geneeskd 1985: 129:958-9. 
56. Ryan CA, Hallgren RA, Finer NN.

The use of povidone iodine in neonatal bowel surgery.

J Pediatr Surg 1987:22:317-9.

57. Gilmore OJA.

An appraisal of the use of antiseptics in surgical practice.

Ann R Coll Surg Engl 1977:59:93-103.

58. Umpleby HC, Williamson RC.

The efficacy of agents employed to prevent anastomotic recurrence in colorectal carcinoma. Ann R Coll Surg Engl 1984;66(3):192-4. 


\section{Chapter 10}

\section{Protocol for the treatment of colonic disease in elective and emergency surgery}

(see also chapter 3)

\section{Elective colorectal surgery (see algorithm)}

All patients admitted for colorectal surgery are organised to undergo a whole gut irrigation with neomycin and metronidazole in the irrigation fluid, provided that the contraindications are taken into account.

Whole gut irrigation is not feasible in those patients admitted with obstruction and intraoperative colon irrigation through the irrigation drainage tube is performed instead.

Preoperative bowel preparation is not possible in a small proportion of patients because of refusal or other contraindications, or is found at operation not to have been satisfactory. Intraoperative colon irrigation with the rectal tube is easily performed, especially if no obstructions are present.

An (extended) right hemicolectomy is the method of choice in obstructing lesions of the right colon without any bowel prepanation.

\section{Non-elective colorectal surgery}

For obstructing lesions of the right colon the procedure to be followed is the same as that in elective colorectal surgery.

Most of the obstructing lesions of the left colon can be handled by the intraperative colon irrigation using the irrigation drainage tube if certain criteria are fullilled.

With non-obstructing lesions intraoperative colon irrigation can be carried oul using the reckal tube, after which resection and anastomosis are performed as in elective colorectal surgery.

For volvulus of the left colon, in which conservative treatment has failed and operation is mandatory, intraperative colon irrigation is feasible either with the irrigation dranage tube or the rectal tube (depending upon the quality of the colon).

A (sub)total colectomy is only justified in cases of toxic megacolon or if pertoration in the caecum has occurred due to distension in the presence of a left sided obstructing tumour. 


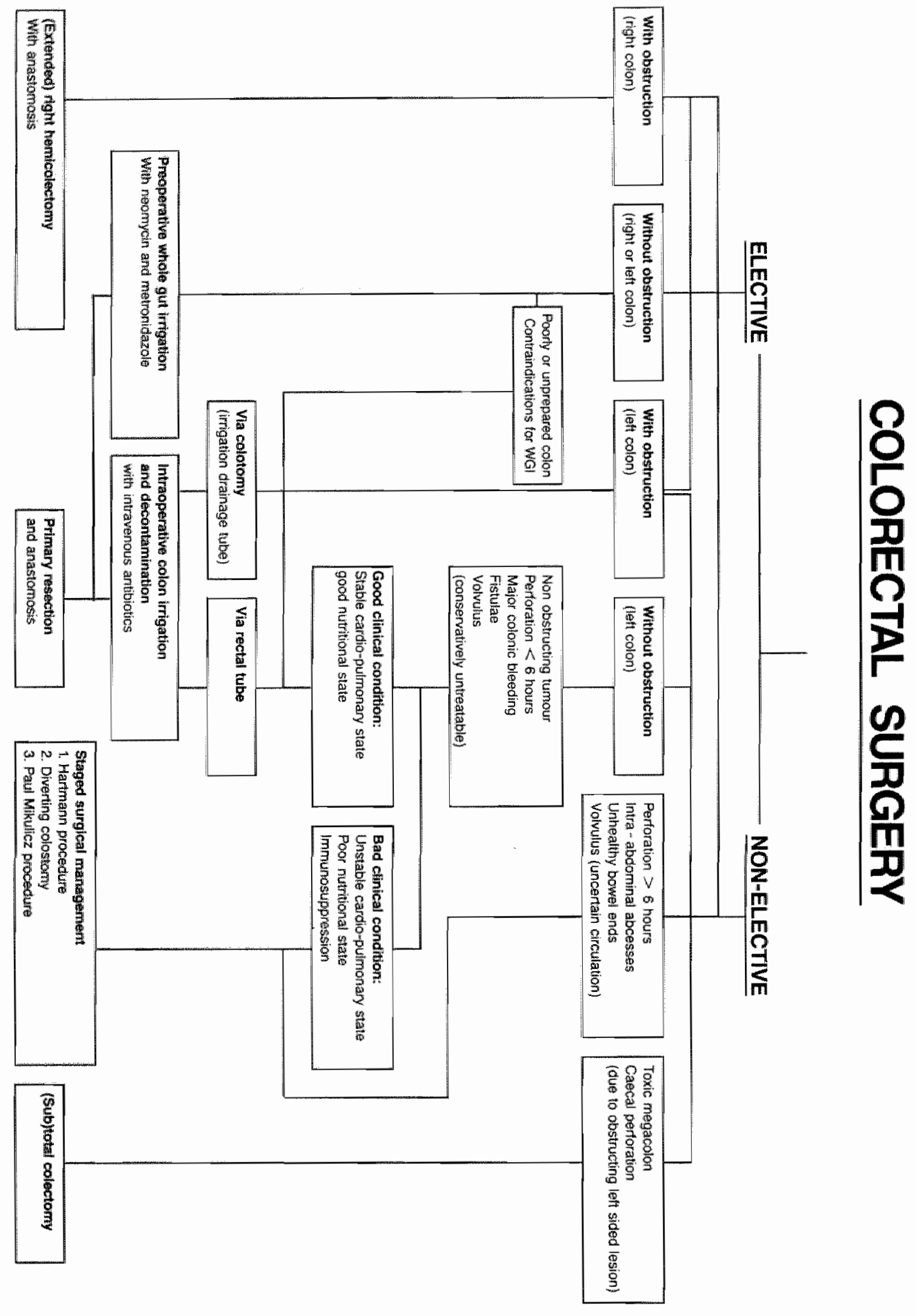




\section{Summary and conclusions}

\section{Chapter 1}

The aims of the studies presented in this thesis are reported briefly in this chapter.

\section{Chapter 2}

The sense or nonsense of bowel preparation is discussed especially in view of the opinions of some workers that bowel preparation is probably unnecessary. Several methods of preoperative bowel preparation are discussed with their pros and cons.

\section{Conclusions}

- Until data from adequate controlled clinical trials prove the contrary, large bowel preparation should be considered essential before colorectal surgery.

- Whole gut irrigation with balanced electrolyte solution or with polyethylene glycol until the rectal effluent is clear, is rapid, economical and well tolerated by patients. This method of bowel preparation is the best for its capacity to clean the colon.

- No reduction of bacterial colonic flora or decrease in postoperative septic complications is to be expected from bowel preparation alone.

\section{Chapter 3}

A historical review is given of attempts to clean the colon during operation in order to perform a primary resection and anastomosis. It resulted at last in the method as described by Dudley, nowadays used as the method of intraoperative colon irrigation. As indications for this procedure are mentioned: obstructing carcinomata, diverticulitis, perforations, major colonic haemorrhage, fistulae, closure of a colostomy and sometimes volvulus.

Contraindications to this procedure concern the suitability of the patient and local factors such as abcess or bowel ischaemia after resection.

The results reported in the literature up to December 1988 are shown in tables 1 and 2 .

\section{Chapter 4}

The results of three prophylactic antimicrobial regimens combined with whole gut irrigation (WGI) were evaluated in 212 patients undergoing elective colorectal surgery.

Three groups were formed at random. The first group (72 patients) were given intramuscular oxytetracycline just before surgery; the second group (70 patients) received oral metronidazole and intravenous tobramycin. The third group (70 patients) received only metronidazole and neomycin in the irrigation fluid. All patients were prepared by WGI on the day before surgery, and the procedure was well tolerated in $95 \%$ of them. In $5 \%$ the irrigation had to be stopped and the patients were excluded from this study. 
Abdominal wound infection occurred in $19.4 \%(14 / 72)$ in group 1 , in $18.6 \%$ (13/70) in group 2 and in $2.9 \%(2 / 70)$ in the group 3 patients. The occurrence of septicamia (group 1 : $11 \%(8 / 72)$; group 2: $9 \%(6 / 70)$; group $3: 0 \%)$ and the overall frequency of anastomotic leakage (group 1: 22\% (14/72); group 2: $17 \%$ (10/70); group 3: $3 \%$ (3/70) were both significanlly reduced in group 3 compared with groups 1 and 2 .

Anastomotic leakage in all patients $(\mathrm{N}=74)$ undergoing anterior resection was investigated radiographically on the 10 th day. A highly significant reduction in the total anastomotic leakage rate was achieved in group 3 . This rate was $7.7 \%(2 / 26)$, compared with $36 \%(9 / 25)$ in group 1 and $26 \%(6 / 23)$ in group 2 .

After this trial had been finished, all patients admitted for ellective colorectal surgery underwent WGI with metronidazole and neomycin in the irrigation fluid. The results in 215 patients studied prospectively with this regimen once again confirmed the data from group 3. It is concluded that very short term antimicrobial prophylaxis with neomycin and metronidazole in the irrigation fluid alone appears to be very effective in reducing wound infections and septicaemia, and -most important of all- yields a dramatic reduction in anastomotic leakage.

\section{Chapter 5}

In this chapter the experience and the results with the intraoperative colon irrigation are reported. Forty-one patients with a mean age of 66 years underwent intrapoperative colon irrigations for various reasons, followed by resection and primary anastomosis of the left colon. A protective diverting colostomy was used in only wo patients with technically imperfect low anterior anastomoses. Uneventful anastomotic healing occurred in all patients, except in two with peritonitis carcinomatosa who developed clinical leakages. In total, four patients died, three from cardiopulmonary complications and one due to the complications of widespread carcinoma together with anastomotic leakage.

\section{Conclusions}

- The intraperative colon irrigation procedure enables us to create an elective environment at "non elective" times in colorectal surgery, permitting a safe one-stage operation in most patients with obstructions of the left colon.

- If certain criteria are fulfilled, this procedure enables primary resection and anastomosis to be performed with a low mortality and complication rate. It offers the patients:

- no stomal problems

- one-stage procedure with single hospitalisation

- shorter hospital stay with financial savings to the community

- better quality of lite.

\section{Chapter 6}

Some new instruments were developed in order to increase the safety and ease of the procedure. With these instruments the intraoperative colon irrigation procedure could be performed withour any spillage at all, as discussed in this chapter and shown in a video film. 


\section{Chapter 7}

The aim of this study was to evaluate the antibiotics used in the clinical trial (chapter 4) in a similar way in an experimental septic model. The question posed was: Can a useful selection or rejection of antibiotic prophylaxis in colorectal surgery be done with this model prior to its application in longlasting clinical trials? The intra-abdominal septic model described by Lahnborg et al. was used for this purpose. Some new antibiotics whose effectiveness in colorectal surgery have been claimed were also tested. Rats, given beef food to change their intestinal flora (which then became comparable with that of humans), were used. Six groups, each containing 12 animals, were formed non selectively and each antibiotic was tested in a separate group. The following parameters for the evaluation of the efficacy of antibjotics were used: time of death, number of abcesses, presence of adhesions, peritonitis. All surviving animals were sacrificed on the 14th day and intra-abdominal assessment of the parameter was done.

The ineffectiveness of oxytetracycline for controlling aerobic and anaerobic septic complications was demonstrated in this model (which was also the case in the clinical study). Neomycin/metronidazole, Augmentin ${ }^{R}$, Timentin ${ }^{R}$ and imipenem were shown to be highly effective for use as prophylaxis.

\section{Conclusions}

- The model of Lahnborg et all. simulating intra-abdominal sepsis has been suggested for predicting the effectiveness of any antibiotic to be used in colorectal surgery. Exclusion or selection of antibiotics seems possible using this model.

- The mortality in this experimental model could not be explained by the increased count of colonic bacteria in animals given beef food. The unbalanced diet, resulting in a decreased general resistance, is probably the most important factor causing the deaths in this septic model.

- Oral administration of neomycin and metronidazole appeared to be very effective in preventing mortality and adhesion formation. The same results were accomplished using parenteral Augmentin $\mathrm{R}$, Timentin $\mathrm{R}$ or imipenem.

- Antibiotics effective against the major colonic bacteria seemed to decrease the extent of intra-abdominal adhesion formation.

\section{Chapter 8}

The main question posed in this study was: could antibiotics prevent the impaired healing of an anasiomosis in the presence of infection?

Five groups containing 24 rats each were formed at randon. Group I received no bowel preparation and no antibiotics. In group 2 whole gut irrigation (WGi) was used as bowel preparation but no antibiotics were given. All rats in group 3 underwent WGI and received antibiotics. In group 4 intraoperative colon irrigation (ICD) was performed ats bowel preparation. Previously infected Vicryl ${ }^{R}$ was used to perform the anastomoses. No antibiotics were given. In group 5 infected Vicry $\left.\right|^{R}$ and antibiotics were used.

Bursting pressure (BP) measurement was chosen as a parameter of anastomotic healing.

No intergroup statistical differences in BP were noted and one might conclude that antibiotics did not influence the anastomotic healing. It is shown that this conclusion is not correct due to the influence of adhesion formation on the BP. 


\section{Conclusions}

- The bursting pressure is unreliable as a parameter for the study of anastomotic healing in fully comparable groups of rats using an infection model, unless the (infected) anastomosis can be studied in complete isolation from adhesion formation.

- ICl as a procedure for obtaining a totally clean colon is safe, rapid and easier to perfom than WGI h animal experiments.

- Antibiotics inthibit adhesion formation $(p<0.05)$.

\section{Chapter 9}

Even high level of appropriate antibiotics do not prevent wound infections in colorectal surgery when there is massive bacterial contamination from the unprepared intestine.

In thus experimental study, methods for decontaminating the colon during the intraperative colon intigation procedure were investigated in-vitro and in-vivo.

Polyvinyl pyrrolidone iodine (PVP-I) has been shown to be a safe and effective broad spectrum antibacterial agent and is known to exert its action rapidly. Therefore this agent was tested for its capacity to decontaminate the colon. Secondly, the influence of oxygen on the anaerobic colonic flora was investigated.

In-viro studies: Faeces obtained from four healthy volunteers and from four rats were exposed to PVP-I and neomycin/metmonidazole.

In-wivo studies: Three groups of rats, each containing of 9 animals, were separated at random. All rats underwent intraoperative colon irrigation with saline. In the control group only intraperative colon irrigation was performed; in the PVP.I group after saline irrigation, the colon was irrigated with $60 \mathrm{ml}$ of $1 \%$ PVP-I. In the oxygen group after irrigation, the colon was blown through with $100 \%$ oxygen for 5 minutes. Twenty minutes after the procedure a $3 \mathrm{~cm}$ segment of the descending colon was excised and prepared for aerobic and anaerobic cultures.

In-vifo studies: Treatment with $1 \%$ PVP-I resulted within 10 minutes in elimination of nearly all aerobic and anaerobic microorganisms $(p<0.002)$. Treatment with metronidazole and neomycin showed a slow reduction in the anaerobes, but no effect at all on the serobic flora within 60 minutes.

In-vivo studies. Significant rapid reduction $(\mathrm{p}<0.0001)$ of the total colonic florat occurred after irrigation with $1 \%$ PVP-I. In the group treated with oxygen, no reduction in the colon flora was noticed.

\section{Conclusion}

PVP.I (1\%) in combination with the intraperative colon inigation, did appear to be highly eflective for acute colon decontamination.

\section{Chapter 10}

The lesions learned from elinical and experimental studies reported in this thesis and which are important for the clinical practice of colorectal surgery are summarised in the algorithm in this chapter. 


\section{Samenvatting en conclusies}

In hoofdstuk 1 worden de doelstellingen van dit proefschrift ('Pré- en intra-operatieve darmlavage en antibiotica in de colorectale chirurgie: een klinisch en experimenteel onderzoek') in het kort besproken.

Op basis van literatuurstudie wordt in hoofdstuk 2 de zin van pré-operatieve darmvoorbereiding besproken. De mening van sommige onderzoekers, dat darmvoorbereiding niet nodig is, wordt kritisch getoetst. Verschillende methoden voor pré-operatieve darmvoorbereiding worden inclusief hun pro's en contra's besproken.

De conclusies hieruit getrokken luiden als volgt:

- Totdat het tegendeel bewezen is door gecontroleerde, klinische, prospectieve studies moet pré-operatieve darmvoorbereiding in de colorectale chirurgie essentieel geacht worden.

- Totale darmlavage met een uitgebalanceerde electrolyt-oplossing of met polyethyieenglycol totdat het effluent helder is, is snel, economisch en wordt goed verdragen door de patient. Deze methode van darmvoorbereiding geniet de voorkeur, gezien hatr vermogen om het colon te reinigen.

- Vermindering van de bacteriële darmflora en van post-operatieve infecties ten gevolge van darmvoorbereiding alleen, is niel te verwachten.

In hoofdstuk 3 wordt een historisch overzicht gegeven van de pogingen om het colon te reinigen tijdens de operatie ten einde een primaire resectie en anastomose uit te voeren. Deze resulteerde tenslotte in de methode zoals die door Dudley beschreven is en die tegenwoordig in gebruik is als dé methode voor intra-operatieve colonlavage. Als indicaties voor deze procedure worden genoemd: obstruerende carcinomen, diverticulitis, perforaties, massaal bloediverlies uit het colon, fistels, sluiten van een colostomie en soms volvulus.

Contra-indicaties bij deze procedure hebben betrekking op de algehele klinische toestand van de patiënt en op locale factoren zoals een abcessen of slechte vascularisatie van het colon na resectie.

In de tabellen 1 en 2 (p. 32-33) wordt een overzicht gegeven van de resultaten met deze methode in de literatur tot januari 1989.

In hoofdstuk 4 worden de resultaten van drie profylactische antimicrobiele methodes. gecombineerd met totale darmlavage, prospectief geëvalueerd bij 212 patiëmlen, dic electieve colorectale chirurgie ondergingen. Drie gerandomiseerde groepen werden gevormd. De eerste groep (72 pat.) kreeg vlak voor de operatie intramusculair oxytetracycline. De tweede groep (70 pat.) kreeg oraal metronidazole en intraveneus tobramycine. De derde groep ( 70 pat.) kreeg alleen metronidazole en neomycine in de spoelvloeistof.

Alle patiënten ondergingen pré-operatief een totale darmlavage. Deze werd door $95 \%$ goed verdragen. Bij $5 \%$ moest het spoelen om diverse redenen worden gestopt, waarna deze patiënten werden uitgesloten van dit onderzoek.

Abdominale wondinfectie kwam voor bij $19,4 \%$ (14/72) van de patiênten in groep 1, bij $18,6 \%(13 / 70)$ ervan in groep 2 en bij $2,9 \%(2 / 70)$ ervan in groep 3. Sepsis (groep $1: 11 \%$ $(8 / 72)$; groep 2: $9 \%(6 / 70)$; groep $3: 0 \%$ ) en het optreden van naadlekkage (groep 1: $22 \%$ $(14 / 72)$; groep 2: $17 \%(10 / 70)$; groep $3: 3 \%(3 / 70)$ waren beide significant verminderd in groep 3 vergeleken met de groepen 1 en 2 . 
De anasitomosen bij alle patienten $(N=74)$ die cen anterieure resectie ondergingen, werd op de 10 dag róntgenologisch onderzocht. In groep 3 werd een hoog significante vermindering wan het totad aantal nadulekkages bereikt namelijk $7,7 \%(2 / 26)$, vergeleken met $36 \%$ $(9 / 25)$ in groep 1 en $26 \%(6 / 23)$ in groep 2.

$\mathrm{Na}$ het beëindigen van dit onderzoek, ondergingen alle patiënten, die voor electieve colorectalie chirurgie opgenomen werden, een totale damlavage met metronidazole en neomycine in de spoelvloeistof. De resultaten bij 215 patiënten, die prospectief bestudeerd werden met deze methode, bevestigden nog eens de resultaten van groep 3 .

Geconcludeerd wordt, dat antimicrobiele profylaxe met neonycine en metronidazole in de spoelvloeistof heel doeltreffend blijkt te zijn voor het verminderen van wondinfectie, sepsis en -het allerbelangrijkste- een aanzienlijke vermindering oplevert van het aantal naadlekkages.

Hoofdstuk 5 bevat de ervaringen met en resultaten van intra-operatieve colonlavage. Eenenveertig patiënten met een gemiddelde leeftijd van 66 jaar ondergingen om diverse redenen intra-operatieve lavage, gevolgd door resectie en primaire anastomose van het linker colon. Slechts bij twee patienten met een technisch onvolkomen lage anterieure anastomose werd een "beschemmende" anus praetematuralis aangelegd.

Bij alle patiènten vond een normale genezing wan de naad plaats, behalve bij twee met peritonitis carcinomatosa. Zij kregen een klinische lekkage. In totaal overleden vier patiënten, drie door cardiopulmonaire complicaties; een patiënt aan de gevolgen van uitgebreide tumormetastasen en tewens naadlekkage.

\section{Conclusies:}

- Met behulp van de intra-operatieve colonlavage hoeven de meeste patienten met een obstructie van het linker collon maar ến keer geopereerd te worden.

- Als aan bepaalde criteria voldaan is, kan primaire resectie en anastomose worden uitgevoend met een laag mortaliteits-en complicatiepercentage.

De voordelen voor de patiènt zijn:

- geen complicaties van een stoma:

- eenmalige operatie en ziekenhuisopname;

- korter verblijf in het ziekenhuis, wat een financiële besparing voor de gemeenschap betekent;

- een kwalitatief beter leven.

In hoofdstuk 6 wordt een drietal nieuwe instrumenten besproken die ontwikkeld zijn ten einde de veiligheid en het gemak wan de procedure te verbeteren. Met deze instrumenten kon de intra-operatieve colonlawage uitgevoend worden zonder enige 'spilling', zoals in dit hoofdstuk is besproken. In een videofilm wordt de techniek van de intra-operatieve colonlavage met behulp van deze instrumenten gedemonstreerd.

Hoofdstuk 7 omvat de beschrijuing en de resultaten van een onderzoek dat tot doel had de antibiotica, die in het klinische onderzoek werden gebruikt, op gelijke wijze in een experimentel infectiemodel te evalueren. De vraagstelling luidde: is met dit model selectie of uitslunting van antibiotica mogelijk, voordat deze in langdurige klinische studies als profylaxe worden toegepast? Voor dit doel werd gebruik gemaakt van het intra-abdominale infectiemodel, zoals beschreven door Lahnborg et al. Ook werden enkele nieuwe antibiotica getest, warvan in de colorectale chirurgie beweend word dat zij doeltreffend zijn. Er werd gebruik gemaki van ratten, die "beef food" kregen om hun darmflora te veranderen, zodat deze vergelijkbaar wend met die van mensen. Er werden a-select zes groepen gevormd, elk bestaande uit 12 dieren. Elk antibioticum werd in een afzonderlijke groep onderzocht. 
De volgende parameters voor de evaluatie van de effectiviteit van de antibiotica werden gebruikt: tijdstip van overlijden, aantal abcessen, aanwezigheid van verklevingen en/of peritonitis. De overlevende dieren werden op de veertiende dag intra-abdominaal geèvalueerd op de aanwezigheid van abcessen, adhesies of peritonitis. In dit model werd de ineffectiviteit van oxytetracycline aangetoond, voor wat betreft het onder controle krijgen van aerobe en anaerobe infectieuze complicaties. Hetzelfde was het geval in het klinische onderzoek. Neomycine/metronidazole, Augmentin ${ }^{R}$, Timentin ${ }^{\mathbb{R}}$ en imipenem bleken bijzonder doeltreffend als profylaxe.

\section{Conclusies}

- Met het model van Lahnborg et al. bleek het mogelijk te zijn de effectiviteir van antibiotica te voorspellen, die als prophylaxe in de colorectale chirurgie gebruikt zouden kunnen worden.

- De mortaliteit in dit experimentele model kan niet verklaard worden door het toegenomen aantal clarmbacteriën. Het onevenwichtige dieet, waarvan een verminderde algemene weerstand het gevolg is, is waarschijnlijk de belangrijkste factor waardoor de sterfgevallen in dit infectieus model veroorzaakt werden.

- Orale toediening van neomycine en metronidazole bleek bijzonder effectief te zijn, wat betreft het verminderen van mortaliteit en adhesies. Dezelfde resultaten werden bereikt met het gebruik van Augmentin ${ }^{\mathbb{R}}$, Timentin ${ }^{\mathbb{R}}$ of imipenem.

- De mate van intra-abdominale adhesievorming bleek verminderd te worden door antibiotica die ook effectief waren tegen een groot deel van de darmbacteriën.

In hoofdstuk 8 is een onderzoek beschreven, waarvan de belangrijkste vratgstelling was: kunnen antibiotica een ongehinderde genezing van de anastomose bewerkstelligen in geval van een lokale infectie?

Vijf groepen, elk bestaande uit 24 ratten, werden 'at randon' gevormd. Groep I kreeg noch darmvoorbereiding, noch antibiotica. In groep 2 werd totale darmlavage gebruikt als darmvoorbereiding, maar er werd geen antibiotica toegediend. Alle ratten in groep 3 ondergingen totale darmlavage en kregen antibiotica. In groep 4 werd intra-operatieve colon lavage toegepast als darmvoorbereiding. Geïnfecteerd VicrylR werd gebruikt voor het maken van de anastomosen. Er werd geen antibiotica gegeven. In groep 5 werd én geünfecteerd VicrylR én antibiotica gebrükt. Het meten van de 'bursting pressure' (BP) werd gekozen als parameter voor het genezen van de anastomose. Er werden geen statistische verschillen in de BP tussen de groepen genoteerd en men zou geneigd zijn te concluderen, dat antibiotica geen invloed hebben op genezing van de anaslomose. Aangetoond wordt, dat deze conclusie niet juist is door de invloed van adhesievorming op BP.

\section{Conclusies}

- De 'bursting pressure' is onbetrouwbaar als parameter voor het bestuderen van de genezing van een anastomose in volledig vergelijkbare groepen ratten, bij het gebruik van een infectie-model. tenzij de (geinfecteerde) anastomose geheel afgezonderd van adhesievorming bestudeerd kan worden.

- In dierexperimenten is de intra-operatieve colon lavage als methode voor het verkriggen van een totaal schoon colon veilig, snel en bovendien eenvoudiger uit te voeren dan de totale darmlavage.

- Antibiotica verhinderen adhesievorming $(\mathrm{p}<0,05)$. 
In de colorectale chirurgie biedt zelfs een hoge antibioticaspiegel geen adequate preventie tegen wondinfecties, indien er bacteriële contaminatie plaatswindt vanuit de onvoorbereide darmen. In deze experimentele studie werden inwitro-en in-vivo-methoden onderzocht om bet colon te decontamineren tijdens de operatie. Het is bekend, dat polywinylpyrrolidonejodium (PVP-J) een veilig en doeltreffend breed spectrum bactericide middel is en dat het snel werkt. In hoofdstuk 9 werd PVP-J onderzocht op zijn vermogen het colon te decontamineren. Bovendien werd de invloed van zuurstof op de anaerobe darmflora nagegaan.

In-vitro onderzoek: faeces, verkregen van vier gezonde vrijwilligers en van vier ratten, werd blootgesteld aan PVP-J en neomycine/metronidazole.

In-wivo onderzoek: drie groepen ratten, elk bestaande uit 9 dieren, werden "at random" samengesteld. Alle ratten ondergingen intra-operatieve colonlavage met fysiologisch zout. In de controlegroep werd alleen intra-operatieve colonlavage uitgevoerd. In de PVP-J groep werd, na het spoelen met fysiologisch zout, het colon nagespoeld met $60 \mathrm{ml} 1 \%$ PVP-J. In de zuurstofgroep werd het colon, na spoeling, gedurende 5 minuten doorgeblazen met $100 \%$ zuurstof. Twintig minuten na deze handeling werd een $3 \mathrm{~cm}$ lang segment van het colon descendens geexcideerd en geprepareerd voor een aerobe en een anaerobe kweek.

In-vitro onderzoek: Behandeling met $1 \%$ PVP-J resulteerde binnen 10 minuten in de eliminatie van nagenoeg alle aerobe en anaerobe micro-organismen $(p<0,002)$. Behandeling met metronidazole en neomycine liet na 60 minuten een langzame afname van de anaeroben zien, doch had geen enkel effect op de aerobe flora.

In-wivo onderzoek: er deed zich na spoelen met $1 \%$ PVP-J, een significante en snelle vernindering voor $(\mathrm{p}<0,0001)$ van de totale darmflora. In de groep die behandeld werd met zuurstof werd geen reductie van de darmflora bemerkt.

\section{Conclusie}

1\% PVP-J bleek, in combinatie met intra-operatieve colonlavage, een bijzonder effectief middel te zijn voor wat betreft acute decontaminatie van het colon.

In hoofdstuk 10 is het algoritme voor de chirurgische behandeling van colonaandoeningen opgenomen. Dit protocol is gebaseerd op de lessen geleerd uit de klinische en experimentele studies die in dit proefschrift beschreven worden en die van belang zijn voor de colonchirurgie. 


\section{Acknowledgements}

This thesis could not have been completed without the enthusiasm and contribution of many people. Although it is impossible to thank everyone for their support. I would like to take the opportunity of expressing my gratitude to those without whose help this thesis could never have been written.

Prof. H.F. Dudley: I consider you as the guest of honour on this occasion. It was you who introduced the intraoperative colon irrigation as it is applied nowadays. I am grateful for your cooperation.

Dr J.D.K. Munting: From you I received the largest part of my surgical training. Your enthusiasm and continuous support were of invaluable help to me in preparing this manuscript.

Prof. dr C.P.A. van Boven: You accepted my preliminary work for a thesis and initiated the experimental studies. I am grateful for your critical views and wholeharted support in finishing this thesis.

Prof. dr J.M. Greep: Your comments and suggestions have contributed much to enhancing the quality of this work.

Drs. A.E.J.M. van den Bogaard: Without your help the experimental work could never have been accomplished. Indeed, I learned the basic principles from you. Your enthusiasm resulted in the production of a professional videofilm in which the intraperative colon irrigation procedure is demonstrated. I would like to express my utmost gratitude for your essential contribution to the experimental studies.

Dr B.I. Davies: You were engaged in the bacteriological evaluation of the clinical studies. Your willingness to discuss the manuscript, whenever asked, has been highly appreciated. I am very grateful for your transformation of 'my' English into a 'real" one.

Prof. dr R.A. Janknegt; Prof. dr P.J. Brombacher; Prof. dr J.A. Gruwez; Prof. dr P.B. Soeters; dr D.J. Gouma, you have all read the manuscript critically and $I$ appreciate your comments.

Many others have contributed and I want to mention them in gratitude:

-The surgeons of the 'De Wever-Hospital' (dr J.D.K. Munting; dr H.van Houtte; dr J. Lens; C.J. van Duin; E. Bollen; dr P. Brink) for the opportunity in completing this thesis. In particular Cees van Duin for his mastery and teaching of the intraoperative colon irrigation procedure.

-The residents of the surgical department for their cooperation in the follow up of the patients; the staff of the surgical wards 10 Oost (head: H.van Gastel); 10 West (head: W. Vondenholf); 9 Oost (head: E.van Gerwen): 8 Oost (head: J.van Gerwen); 8 West (head: M. Royen); the out-patients department (head: W. Hollanders); the out-patient operating theatre (head: A. Verluyten); the operating theatres (heads: G. de Esch and W. Geenen); the medical archive service (head: N.van der Molen) the department of medical photography (F. Goutier); the pharmacy (M. Mol, J. Branje, H. Cremers) the department of pathology (head: $\mathrm{dr} J$. Koudstaal); the department of radiology (head: $\mathrm{dr}$ J. Lamers); J. Gronenschild and the department of medical microbiology (head: dr B.I. Davies).

-The surgeons" secretariat (head: M. Spaans); the public relations' secretariat (I. Heller); the directors' secretariat ( $\mathrm{N}$, van den Beucken and J. Wimmers); Chris de Waal: Tom Schiphorst; Ruud van Loenhout; Lilian and Bert Nelissen for their contributions. 
-Romy Clignet and Miriam Vincent (medical librarians) for much more work than just collecting the literature.

-Henk Sprengers and the department of material services (head: P. Steinmann) where Ton Lendfers unselfishly prepared the illustrations; Jan Peeters and W. Römkens cooperated in the construction of the irrigation needle and the irrigation dramage tube.

-The staff of the department of Centralised Experimental Animal Facilities of the State University of Limburg (head: drs. A.E.J.M. wan den Bogaard) for their support in the organisation and performance of the experiments: Lucienne Niesen; Evert van Dam; Frans Weekers; Peter Kelderman; Petra Rommers.

In particular: May Bost for the construction of the rectal tube, Math Hazen for the accomplishment of the many bacteriological cultures, Huub Houben for the statistical analysis of the experimental work. Members of the medical photography department for the quality of the pictures of the experiments.

-Alex Volovics: Il owe you a great deal for your statistical evaluation of chapter 4.

"Thanks to the "paranimphs" Joris Hage and Jean Reinders for their valuable assistance.

-Last but not lexist special thanks to Mieke; the kids for fanatic painting, happily only on those pages of the manuscript that I no longer needed.

The publication of this thesis has been financially supported by:

the reseanch funds of De Wever-Hospital, the surgeons of De Wever-Hospital, Beecham

Pharma BV, Dagra Pharma BV, Nutricia BV, Glaxo BV and Merck Sharp \& Dohme BV. 


\section{Curriculum vitae}

Naam:

Voornaam:

Geboren:

1971

1978

Juli - oktober 1978

Maart 1979 - mei 1981

Juni 1981 - juli 1986

Juli 1986

Vanaf juli 1986

Vanaf juli 1988
Mahabier

Chandrebhan

23 november 1949 in het district Nickerie in Suriname.

eindexamen HBS-B te Paramaribo.

arts-examen aan de Rijksuniversiteit te Leiden.

arts-assistent chirurgie en obstetrie/gynaecologie in het Rijnoordziekenhuis te Alphen aan de Rijn.

B-opleiding chirurgie in het Zeewegziekenhuis te Velsen (Opleiders: F. Schreuder; dr W.J. Tinbergen).

opleiding tot chirurg in het De Wever-Ziekenluuis te Heerlen (Opleider: dr J.D.K. Munting).

inschrijving in het specialistenregister.

werkzaam op de afdeling chirurgie van het De WeverZiekenhuis te Heerlen.

chef de clinique van de afdeling chirurgie van het DeWever-Ziekenhuis te Heerlen. 


\section{Lay out: Hein Berendsen}

De Wever-Hospital Heenlen (NL/Bureau Public Relations

1989.

Wüh Apple Aacintosh, font Tintes. Printed by Druktkert + Repro Van Hooren. Heeten (NLJ.

No part of this book may be reproduced in any form by print. photoprint. microfilm or any other means without permission from the author. 